\title{
GRAMMATIKALE AANTEEKENINGEN VAN HET TABAROESCH, TABAROESCHE VOLKSVERHALEN EN RAADSELS. ${ }^{1}$ )
}

DOOR

J. FORTGENS.

Het Klankstelsel.

Het Tabaroesch is een zuiver vocalische taal. Het kent geen enkel woord met gesloten lettergrepen. Zelfs de uit het Maleisch of andere talen overgenomen woorden worden:

1e, van den consonantischen eindsluiter ontdaan: sumu, put; M. soemoer; djara, paard; Jav. djaran; turu, nadoen, namaken; M. toeroet; tjere, ketel; M. tjerek; kawi (alleen in kawimaidja, huwelijksprijs = bruidschat); M. kawin; muri, leerling-medium; M. moerid; tjotjoro, trechter; M. tjorong; kapa, watten, boomwol; M. kapas; kapita, aanvoerder in den oorlog; Port. kapitan; goba, $2 \frac{1}{2}$ cent ; M.M. gobang; bawa, ui ; M. bawang.

2e, de consonantische sluiter wordt doorklinkend gemaakt en wel zoo, dat op dien sluiter dezelfde vocaal volgt als die van de voorafgaande lettergreep of door een i gevolgd wordt: sawana, ontstellen, bleek worden van schrik (voor "schrikken” heeft het Tab. een eigen woord in todokana) van M. sawan, stuipen; saraha, overgeven, overleveren; M. serah; hatibi, Moh. geestelijke; M. chatib; gomatere, medium; M. gementar, beven, rillen; ratusu, honderd; M. ratoes; bibiliana, koopprijs (een door den Sultan van Ternate vastgestelde som geld, in ruil waarvoor hij natuurprodukten ontvangt, welker waarde verre den koopprijs overtreffen) van M. beli-belian,

1) Wijlen dr. N. Adriani bezocht in 1910 o.m. ook de Westkust van Halemahera, waar ik vanaf 1902 gegevens verzameld had van het Tabaroesch, een der in die streken gesproken talen. Onder voorlichting van dr. A. werkte ik die gegevens uit en vulde die an met klankvergelijkend materiaal uit het Ternataansch, Waiolisch en Sahoesch, waaruit in 1914 dit artikel in den hier gegeven vorm ontstond en eerst heden, 1928, in het licht gegeven wordt. 
koopwaren; kapali, schip; M. kapal; akali, raad, middel, list; M. 'akal; nanasi, ananas; M. nanas; sangisara, lijden, kwelling; M. sengsara, enz.

K linkers.

a, e, i, o, u.

(Wij geven de voorkeur de oe in het Tab. als $u$ te schrijven, aangezien in een aantal woorden de verbinding voorkomt van de klinkers $o$ en e, en in een menigte woorden de klinker $u$ verdubbeld wordt.)

Tweeklanken komen in het Tab. niet voor. In woorden, waar twee klinkers (hetzij dezelfde, hetzij verschillende) naast elkaar staan, hebben zij elk een afzonderlijke uitspraak en vormen een afzonderlijke lettergreep:

aili, duizendpoot, lees: a-i-li; sauku, warm, lees: sa-u-ku; lciti, (in gialeiti, pink) lees: $l e-i-t i$; (de veel gevolgde schrijfwijze heira in Halemahera is foutief ; het laatste woord is hera en niet he-i-ra); moroini, mak, tam, lees: mo-ro-i-ni; biusu, opstoken, lees: bi-u-su; uiti, hoozen, lees: $u-i-t i$; peleuru, omhalen, omtrekken, lecs: $p c-l c-u-r u$, enz. Zooals verder zal worden aangetoond, máakte oorspronkelijk de tweede klinker met den daaropvolgenden médeklinker één lettergreep uit : $a-i-l i$, oorspr. $a-i l ; s a-u-k u$, oorspr. $s a-i u k$; $l e-i-t i$, oorspr. le-it, doch aangezien de consonantische eindsluiter doorklinkend werd gemaakt door dezelfde als aan den medeklinker voorafgaande klinker te laten volgen, vormt thans de voorafgaande klinker een afzonderlijke lettergreep en de daaropvolgende medeklinker + klinker een nieuwe lettergreep.

De klinkers hebben tweeërlei uitspraak, welke zich richt naar een open of gesloten lettergreep. Alhoewel de vocalische aard der taal geen enkelen consonantischen sluiter toelaat en wij dus niet kunnen spreken van een "gesloten lettergreep" in dien zin, zooals dat b.v. bij het Mal. of een andere consonantische taal het geval is, zoo kent het Tab. toch ook een ,gesloten lettergreep”, wanneer men daarbij let op de uitspraak. Deze heeft dan de beteekenis van een lettergreep, welker klinker een gesloten uitspraak krijgt, doordat de volgende lettergreep begint met een tenuis $(\mathrm{k}, \mathrm{t}, \mathrm{p}, \mathrm{tj}$,) of $\mathrm{s}$ (als de klinker den klemtoon heeft) of nasaal. Het Tab. noch de aanverwante dialekten bezitten onvolkomen klinkers, evenmin de pěpĕt, vandaar dat het onnoodig is door accenten de waarde der vocalen aan te geven, aangezien die waarde bepaald wordt door de vocaal of consonant, waarmee de volgende syllabe begint. De eenige teekens, welke wij 
noodig vinden te gebruiken, is de accentueering bij anderen klemtoon dan de regel aangeeft, nl. de derde lettergreep van achteren (wat, zooals verderop zal aangetoond worden, taalkundig onjuist is uitgedrukt (zie blz. 329).

Voorts een - boven de vocaal, waar volgens de waarde een dubbele moet staan, doch ter vereenvoudiging tot een enkele vocaal met een streepje-er-boven beperkt is; b.v. koóo $=k o \bar{o}(\mathrm{Gal}$. kolólo $)$, omhelzen; goóoro $=$ goōro, staat voor gososoro (Gal. gosóso), olie; talaáa $=$ tala $\bar{a}$ (Gal. talaája), gierig, enz.

Daar het Tab. geen geprenasaleerde klanken kent, zoo is het steeds een enkele nasaal, welke op den klinker eener syllabe volgt, weliswaar als beginner der volgende lettergreep, maar deelt toch ook als nasaal aan den klinker der voorafgaande lettergreep een half gesloten uitspraak mede.

Geheel open is de uitspraak der klinkers, die gevolgd worden door een anderen klinker, hetzij dat deze dezelfde is of een andere. Toch meene men niet, dat deze uitspraak gelijk staat met die van de volkomen klinkers in het Nederlandsch; oara, hardloopen, spreke men b.v. niet uit alsof er stond oo-aa-raa. Alleen maakt de $o$ vóór $u$ hierop een uitzondering. In alle gevallen, waar op de $o$ een $u$ volgt, klinkt de $o$ als de volkomen $o$ in het Nederlandsch; souru, geneesmiddel, spreek uit: soo-oc-roe.

De open uitspraak komt voor in alle andere gevallen, waar de klinker niet gevolgd wordt door een lettergreep, welke als beginner heeft een tenuis $(k, t, p, t j)$.

Voorbeelden :

a geheel open :

(aa) maata, koud; damáa, wachten op; tagaása, e.s.v. mand;

(ae) batáe, bewaren; macke, beschaamd ; kacrasa, krab;

(ai) saidi, bezien; ngairi, beekje; aili, duizendpoot;

(ao) waoko, gevreescle vogel; ao, vasthouden; baoro, te voorschijn komen;

(au) sauku, warm; aunu, bloed; nauru, man;

a open :

$a b a$, vader; ara-ara, spin; adana, vlechten van baaltjes enz.; kalubahári, zeegewas (M. akar bahar); wawáko, instrument om touw te draaien; basarama, waringin; sali, met wisselwoorden spreken. 


\section{a gesloten :}

(k) kakatama, tang; osaka, gaar, rijp; sakara, steken;

(t) tatara, veelvuldige hakken geven overlangs in een bamboe om die te kunnen openvouwen;

atete, blijven haken; fato, naast elkaar op een rij;

(p) apu, grootmoeder; tapádu, drukken; tatápa, wan ;

(tj) gurátji, goud; tjatjáki, kalkpotje;

(s) asa, dragen; pasa, voorbij, verleden; asi-asiri, tong;

nasaal halfgesloten:

nganga, plagen; emama, oom, vader; panja-panja, afhangend; nanere, droomen.

e geheel open:

(ea) pereanga, wijduitgespreid (van armen, beenen, takken); dea, vader ; eanga, openspalken;

(ee) papadeeke, kikvorsch; pereeke, modderig; gegeeke, restant klapper, dat na het raspen nog aan den dop zit;

(ei) leiti, in gialeiti, pink; abeíka, komaan, zie eens; nenéi, langzaam;

(eo) leoto, voor anker gaan; meseoso, rib; pcleoko, rekken van het lichaam;

(eu) keléu, schuinkijken (uit ontevredenheid); peleuru, wrikken, omdraaien ; meleumu, boschkip;

e open :

edete, grootouders; dobele, vloed; asere, achtersteven; hera, in otimahera, kleinste vlerkprauw, en in Halemahera;

e gesloten:

(k) beléka, schouder; peleke, stooten; pooteke, breken (van glas);

(t) teto, steen; tetewerete, dreigen met den vinger; eto, dronken;

(p) pepu, huilmondje trekken; lepa, plas; pepéke, modder;

(tj) kalabétju, sarong tusschen de beenen doorhalen en van achteren insteken; tjetjeretjetje, bevuilen (van afgang);

(s) ese, halen; pesaka, nat; tesongo, zeggen;

nasaal halfgesloten:

menga, voorhoofd ; pelénga, opendoen ; eme, moeder; reno, knagen ; njenjére, geluid van den satan;

De i heeft slechts één uitspraak, hetzij deze voorkomt in een open of gesloten lettergreep; de uitspraak is altijd als die van een volkomen i. 
iete, lachen; gigie, heuvel; niiki, volgen; tumudiingi, getal zeven; tiosaka, schuw; gigilioro, kruin; iunu, verbergen; gitizviri, nagel, hoef ; iniki, verscheidenheid ; ingiri, tand; risiki, tandvleesch; diwizviri, gedreun; rikimi, dicht van regen; wirikiti, draaiend erin brengen (in een gat).

o geheel open :

(oa) soata, vier; oara, hardloopen; tosoana, haan;

(oe) roese, lichaam; woore, drogen in de zon; oe, ja;

(oi) moroini, gewend, mak; toimi, boog; soi, verwisselen;

(oo) goōro, olie; kooromo, inwikkelen, omhullen; mooroko, mondspoelen;

(ou) souru, geneesmiddel; bounu, geur, lucht; ouku, bamboevat voor water en eten.

o open :

ora, rooven; boboro, nipa; mosolese, maagd ; mogiooko, tien; tohe, pruimtasch; moli, zwager(in).

o gesloten:

(k) okoko, kin; onoko, waterscheppen ; tipóko, kort;

(t) toto, ingewand, merg, pit; doto, scherp; gota, hout ;

(p) poposo, stomp; topoko, steken; popa, slaan met den platten kant van 't hakmes;

(tj) boboótja, rheum. gewrichtsaandoening; tjotjóro, trechter;

(s) boso, pan; oso, penis; soso, vliegen.

nasaal halfgesloten:

topongono, doof; ngongodówo, sleutelbeen;

surono, opening, gat; odomo, eten.

Evenals de i heeft de $\mathrm{u}$ slechts èèn uitspraak, nl. de open: wruaćka, naakt; tuara, 't kookpunt bereikt hebben; bubuaele, wilde pisang; uere, vlechten; due, bord; guguiti, waterschepper (in de prauw); luluiti, strijkstok; muduoro, schoonzuster (vrouw van jongeren broer); murúo, hoeveel; nguиsumu, alang-alang; uunu, oplezen; pululunu, rond; ngungúdi, roer; bubusuku, bindsel, verband; tutuduku, pootstok van de rijst.

$\mathrm{Ha} 1 \mathrm{f} \mathrm{k} 1 \mathrm{inkers.}$

$\mathrm{Er}$ is eigenlijk maar één halfklinker, die als zoodanig in aanmerking komt en dat is de $\mathrm{j}$. Aan het begin der woorden wordt 
de $\mathrm{j}$ gehoord met een zeer kort aangehouden i-klank als voorslag. Midden in een woord klinkt zij als de Nederlandsche. De $j$ is schaarsch in Tab. woorden vertegenwoordigd en wij gelooven niet ver van de waarheid te zijn, door te veronderstellen, dat zij niet oorspronkelijk is. De weinige woorden, waarin zij voorkomt, zijn dan ook meestal aan het Tern. ontleend.

jo, meervoudsvorm 3e ps; ja, objectspronomen 3e ps; jaja, vader (aanspreeknaam door kinderen); jaba-jaba, atap (zonder klemlat); dadajoranga, e.s.v. heester; jogo-jogo, snel, vlug; kojongunu, kietelen; koju, wisselwoord voor bole, pisang (uit Tern. koi).

In sidajosanga, vergeten, is de $j$ uit de $w$ door den palatiseerenden invloed van de $i$ der eerste lettergreep ontstaan; het grondwoord wosa komt in het Tern. en Gal. voor (Tob. wohanga; Lod. odjanga; Saoesch: sidajoranga) Tab. osanga; dit laatste staat dus voor wosanga.

De uitspraak der $w$ is bilabiaal; in het algemeen klinkt zij zeer zwak. Tusschen o of $u$ en een volgenden klinker is zij niet anders dan een zeer zachte $\mathrm{w}$, die steeds ontstaat, waar een labiale klinker door een anderen klinker wordt gevolgd, vandaar dat de $\mathrm{w}$ hier en daar in het Tab. ontbreekt, waar zij in de verwante talen optreedt, zoowel aan het begin als in het midden der woorden.

Voorbeelden :

wawáko, touwdraaihaspel; siwo, negen; wusi, kam; wosama, binnengaan; wema, bamboesoort; dowóra, ijzerhout; sasáwi, klapperdơp; lisáwa, hevigste vorm van framb. trop.; wange, zon, dag; wewe, titel voor oom; iwei, rotan.

De benedenland-Tabaroe (op z'n ternataansch worden de Tabaroe cnderscheiden in Tabaru-njeku, bovenland-Tabaroe en Tabaru-adu, benedenland-Tabaroe) hebben een nog sterkere neiging de $w$ te verwaarloozen, zoodat zij die niet meer laten hooren, zoowel aan het begin als in het midden der woorden:

koiiaka; koiizraka, is er niet meer;

ekata; wekata, echtgenoote;

osama; zosama, binnengaan;

ngoaka; ngowaka, kind;

ngeéka; ngewéka, vrouw ;

uaka; wwaka, blazen; 
daongo; dazwongo, in ontvangst nemen;

iwisi; wiwisi, zuigen;

saleana; salewana, oude sarong.

In de volgende Galelasche woorden hebben de Tabaroesche equivalenten de $\mathrm{w}$ laten wegvallen:

bawo; baoro, tevoorschijn komen;

bawo; baoso, stroom in zee;

bolówo; boóto, recht, strak;

inagaze ; magáe, ijverig;

inogiowo; mogiooko, tien;

nawo; naoko, visch;

ngowo; ngoono, restanten, die na uitpersing overblijven;

wosono; osono, nuchter blijven, vasten;

z'oma; omasa, ademen;

turuni; tuunisi, obstipatie;

tuwo; tuono, achterelkaar, in een rij;

sawo; sao, inpakken ;

talaaja; talāa, gierig.

Zie verder over de $\mathrm{w}$ bij de behandeling der labialen onder $\mathrm{p}$.

Medeklinkers en klankafwisseling.

Velaren.

De k klinkt als die in het Mal. en Ned.

kakuru, hoog, lang; kiopiki, zuur; kokówa, pandan; kukisi, bloemknop van de pisang; murukakata, fluim; kiáka, vr.vnw. waar; $d a k u$, boven; $u k u$, vuur.

In het Waiolisch, Sahoesch en Modolesch valt de $\mathrm{k}$ in de equivalenten weg en ontstaat een strottenhoofd-explosief (faucaal hamza), welke in het Tab. niet voorkomt, in welke laatste taal alle vocalen in de uitspraak aan elkaar worden verbonden, zoodat tusschen een labialen klinker en een daaropvolgenden anderen klinker de overgangsklank w wordt gehoord.

Voorbeelden :

oamaka (o amaka), oakere (o akere), poadana;

tusschen een palatalen klinker en een volgenden anderen klinker wordt overgangsklank $\mathrm{j}$ gehoord: toniotaka, biono, aniosu (ani osu); 
tusschen a en een volgende e wordt een zeer lichte i gehoord: maéta, paése, taéta, enz.

Voorbeelden :

\begin{tabular}{|c|c|}
\hline & Saoesch-Waiolisch \\
\hline$u k u$ & $u ' u$, vuur ; \\
\hline ngekomo & ngo'omo, weg; \\
\hline aako & la'o, oog ; \\
\hline ngauku & ngau'u, oor ; \\
\hline pokoro & po'olo, buik; \\
\hline akeme & la'eme, vleesch; \\
\hline ngowaka & ngozea'a, kind; \\
\hline oluku & $o d u$ ' $u$, niet willen; \\
\hline osiki & ori $i$, baden ; \\
\hline sike & si'ere, een wind laten; \\
\hline tonaka & tana'a, grond; \\
\hline kongoro & 'ongoro, traan; \\
\hline momiki & momi'i, opstaan; \\
\hline moteke & mete'e, volgen; \\
\hline wozvóki & wowó'i, eivrucht; \\
\hline akunu & nga'unu, kunnen; \\
\hline beléka & beléasa, schouder; \\
\hline poaka & poa'a, schreeuwen; \\
\hline munúka & munúa, eenige; \\
\hline amaka & lama'a, hangende bamboetafel; \\
\hline saki & $s a^{\prime} i$, vet; \\
\hline wariki & wadi' $i$, openleggen; \\
\hline dotoko & dotóo, leeren ; \\
\hline peréki & piríi, oud. \\
\hline Tabaroesch & Modolesch \\
\hline gakaka & $g a$ 'a, verhemelte; \\
\hline okoko & o'o'o, kin ; \\
\hline gotoaka & gotoa', wang; \\
\hline bubúku & bubú'u, knie; \\
\hline akeme & a'eme, vleesch; \\
\hline ngewéka & ngewéa, vrouw ; \\
\hline riaka & lia'a, oudste kind; \\
\hline wekata & we'ata, echtgenoote; \\
\hline okere & o'ele, drinken; \\
\hline oko & $o^{\prime} o$, staan; \\
\hline
\end{tabular}

Dl. 84 . 


$\begin{array}{ll}\text { moku } & \text { mo'u, op den schouder dragen; } \\ \text { nako } & \text { na'o, weten; } \\ \text { ioko } & \text { io'o, faeces; } \\ \text { aikokáu } & \text { a'o'áu, reeds beter; } \\ \text { meki } & \text { me'i, spook; } \\ \text { tokata } & \text { to'ata, vampyr; } \\ \text { tingaka } & \text { tinga'a, scheiden; } \\ \text { libúku } & \text { libu'u, hoek; } \\ \text { kibiti } & \text { 'ibiti, speeksel; } \\ \text { sakái } & \text { ha'ái, koken; } \\ \text { bikini } & \text { bi'ini, staart; } \\ \text { boki } & \text { bo'i, poes; } \\ \text { ngoku } & \text { ngo'u, witte duif; } \\ \text { pakaka } & \text { pa'a'a, klein soort slang; } \\ \text { kai } & \text { 'ai, huid; } \\ \text { kadu } & \text { 'adu, pruimtasch; } \\ \text { saaka } & \text { hala'a, zilver; } \\ \text { omuku } & \text { omu'u, rijp; } \\ \text { kakatama } & \text { 'a'atama, tang; } \\ \text { kiáka } & \text { 'iá'a, vr.vnw. waar; } \\ \text { okía } & \text { o'ía, vr.vnw. wat; } \\ \text { besaka } & \text { beha'a, regen; } \\ \text { tereboko } & \text { terebo'o, rood; } \\ \text { koana } & \text { 'oana, vorst. }\end{array}$

In het Tab. verschijnt de $\mathrm{k}$ steeds op haar regelmatige plaats. Een enkel voorbeeld is voorhanden, waar zij uitvalt, zonder dat daardoor een hamza ontstaat:

sawaunu, schild; Gal. salawaku (ook M.M. en Tern.); sawaunu staat dus voor sawakunu (Mod. hawa'unu), dat weer staat voor salawakumu, welke laatste vorm aldus in het Lod. voorkomt.

De regelmatige afwisseling van de tenuis als aanvanger bij werkwoordelijke stammen met de media van hetzelfde geslacht bij de nomina is, hoewel in den grond een zuiver phonetisch verschijnsel, thans geworden tot een aanduiding van grammaticaal waardeverschil. Dit verschijnsel zal daarom behandeld worden bij de woordvorming.

De $\mathrm{g}$ heeft dezelfde uitspraak als de maleische en heeft geen af wisselingen : 
gogo, huidhaar, veeren; gogama, 't koud hebben; uge, groente; gigikiri, veger; giama, arm, hand; gugumu, heiligbeen; gigilioro, kruin; gigíe, hoogte, heuvel.

\section{Nasalen.}

ng als de maleische ng.

ngasi, Cordyline terminalis; nganga, plagen; ngomi, wij (excl.); ngai, hulptelwoord; dangono, kleinkind; nanga, ons (incl.); ngangawene, wisselwoord voor kleeding; ngooto, zee; utongo, bladsteel v. d. sagopalm; ngingitiri, slaap (voorhoofd).

De consonanten $\mathrm{k}$ en $\mathrm{g}$ komen niet geprenasaleerd voor. De klanken ngk, ngg kent het Tab. niet, evenmin als nt, nd, ntj, ndj, mp en $\mathrm{mb}$. In de uit andere talen overgenomen woorden, die deze klanken bezitten, worden deze in het Tab. resp. tot $\mathrm{k}, \mathrm{g}, \mathrm{t}, \mathrm{d}, \mathrm{p}$ en $\mathrm{b}$ teruggebracht. Dit verschijnsel is algemeen in de dialekten van NoordHalemahera.

Voorbeelden uit het Tab. zijn:

ngk naka baláda, zuurzak, uit Mal. nangka belanda; samáka, watermeloen, uit Jav. semangka; sakara (in: sakara ma aako, motief van een vlechtmat, genaamd oog (maas) van de kooi) uit Mal. sangkaran; boráka, geul, gracht, uit Port. baranca, (barangka); ngg piga, schaal van porcelein, uit Mal. pinggan; domigu, Zondag, uit Port. dominggo; roge, nationale dans, uit Jav. ronggeng, dansmeid;

nt paréta, bevel, regeering, uit Mal. perintah;

betengi, versterkte plaats, uit Mal. bénténg;

taduku, hoorn, gewei, uit Mal. tandoek;

batungu, bondgenoot in den oorlog, uit Mal. bantoe;

rata, e.s.v. mand, uit Mal. rantang;

rate, ketting, uit Mal. rantai;

guti, schaar, uit Mal. goenting;

potiána, vampyr, uit Mal. pontianak;

ngati-ngati, oorringen, uit Mal. anting-anting;

nd dedengi, gedroogd vleesch, uit Mal. déndéng; tjitjikóde, haarspeld, uit Mal. tjoetjoek konde; pade, knap, uit Mal. pandai;

Het woord voor „,venster”, djangéla is niet ontleend uit het vermaleischte djendéla, maar uit het Port. djenela.

ntj atjaki, bamboehorde, uit Mal. antjak;

kutji, sluiting, uit Mal. koentji;

katji, knoop, uit Mal. kantjing; 
ndj karádja, mand, uit Mal. kerandjang;

djadji, beloven, uit Mal. djandji;

padji, vlaggetje, uit Mal. pandji;

mp tatapa, wan, uit Jav. tetampa;

lapura, lamp, via Mal. lampoe;

tjapáka, Plumeria acutifolia Poir. uit Mal. tjempaka;

supi-supi, blaasroer uit Mal. soempit;

sarápa, waterpokken Mol. Mal. sarampa;

kopani, Compagnie;

mb kabingi, geit, uit Mal. kambing;

pobo, duif, uit Mal. pombo;

suba, huldigen, uit Mal. sembah;

surabi, afdlak vóór een huis, uit Mal. serambi;

tabaga, koper, uit Mal. tembaga;

tabako, tabak, uit Mal. tembakau;

gabiri, uit Mal. gambir.

Van de ng valt nog te zeggen, dat zij hier en daar verschijnt op plaatsen, waar in de verwante dialekten $\mathrm{n}$ staat. Het is evenwel niet altijd uit te maken, wanneer een klankreeks ng, $n$, af wisselt met $n$, $\mathrm{ng}$, in de verwante dialekten, of men te doen heeft met een omzetting dan wel met verwisseling van nasaal.

Voorbeelden :

singina, gemoed, gedachten, Gal. sinínga (Tob. hininga; Lod. sinjia; Saoesch-Wai. sinjingara; Tern. sonjinga); alleen in het samengestelde sininga-laha (iemand een goed hart toedragen) staat de ng op dezelfde plaats als bij de andere dialekten, doch dit woord is waarschijnlijk overgenomen; songene, sterven, Gal. sone (Tob. honenge; Lod. sonenge; S-W. sengene; Tern. sone); ngununu, neus, Gal. Tern. ngunu (Tob. Lod. Mod. ngunungu; Pagoe unung); dungunu, schoondochter, schoonmoeder, Gal. dunu (Tob. Lod. S-W. dunungu; Tern. dun; Pagoe dunung); dangono, kleinkind, Gal. Tern. Pagoe dano (Tob. Lod. S-W. Mod. danongo).

Opmerking: In de gevallen singina, songene, dungunu heeft wrsch. omzetting van de nasalen plaats gehad en wel bij het klinkend-maken van den eindmedeklinker, dus oorspronkelijk sining wordt dan Tab. singina, enz. Als bewijs hiervoor zou het Pagoe umung, neus, (M.P. hidoeng, illong, enz.) kunnen dienen; unung 
wordt Tob. ngunungu en dus weer eigenlijk Tab. ngungunu, maar de ng aan het begin van het woord wekt dissimilatie op en zoo ontstaat ngununu.

Voorts heeft het Tab. de neiging om de $\mathrm{n}$ in woorden, welke het uit andere talen overneemt, tot ng te maken, uit welk verschijnsel de conclusie te maken is, dat we hier zeker met een verwisseling van nasaal te doen hebben.

Voorbeelden :

seng, cent, uit het vermaleischte sén;

likitong, verb. dukaton;

badang, lichaam (alleen in badang masongóna $=$ halve vadem),

Mal. badan;

sikazvingi, motief van vlechtpatroon, uit Mal. kawin;

basutángi, uit Mal. manggistan, bekende vrucht;

serang, eiland Séran (Ceram).

Supradentalen.

$\mathrm{t}$, gelijk aan de maleische $\mathrm{t}$.

potiti, navel; teto, steen;

titi, varken; mutiti, zoet; toto, ingewanden, pit ;

toteke, kloppen; atete, blijven haken; itomo, voortduwen; tutuku, stompen.

De $t$ wisselt af met de $d$ ter anduiding van het verschil tusschen verbum en nomen.

$\mathrm{d}$, als de $\mathrm{d}$ in het Maleisch.

dadamunu, dek, deksel; dodoto, jongere broer, zuster;

modídi, twee; dadakoro, klopper; adedéc, ach, wee;

duuduku, luiheid; idongo, soort visch;

dadadoko, vuurwaaier; didilongo, vlechtmatje;

dadánu, oppassen.

De $\mathrm{d}$ is soms aan het begin af- en in het midden der woorden uitgevallen:

ese, nemen, halen; Gal. dehe;

asini, drijven; Gal. dasi;

asiri, slikken; Gal. dasi;

aeme, likken; Gal. lade;

olu, overstroomen; Gal. dolu;

oboso, gezwollen; Gal. dobo;

enaka, wisselwoord voor betel; Gal. dena; 
maeke, beschaamd; Gal. made;

maata, koud; Gal. mada.

Verder blijkt, dat in het Tab. minstens twee verschillende d's hebben bestaan, die thans echter in uitspraak aan elkaar zijn gelijk gemaakt. Dit oorspronkelijk verschil wordt duidelijk uit de afwisseling in de verwante dialekten, daar de eene $d$ wordt vertegenwoordigd in het Gal. door d, in het Tob. door 1, in het Lod. door $\mathrm{dj}$, in het Saoesch-Wai. door $\mathrm{r}$ en in het Tern. in de meeste gevallen door $\mathrm{h}$, een enkele maal door $\mathrm{nj}$.

\section{Voorbeelden :}

odomo, eten; Gal. oḍo; Tob. olomo; Lod. odjomo; S.-W. oromo; Pagoe ojom; Tern. oho;

modóka, trouwen; Gal. moḍóka; Tob. molóka; Lod. modjóka; S.-W. moloara; Tern. monjóka;

todomo, puntig, scherp; Gal. todo ; Tob. als Tab. Lod. todjomo; S.-W. toromo; Tern. toho;

wekata, echtgenoote; staat voor wekat uit wekad en dit een omzetting van wedak, vocalisch: wedaka; Gal. pedeka; Tob. hekata; Lod. wedjéka; S.-W. weréa; Tern. fohéka; Mod. we'ata;

ngewéka, vrouw; Gal. ngopedéka; Tob. ngohéka; Lod. ngowedjéka; S.-W. weréa ; Tern. fofohéka; Mod. ngowe'a; dabo, wond; Gal. dabo; Tob. labo; Lod. djabo; (in de drie laatste dialekten heeft dit woord een werkwoordelijke beteekenis, nl. verwonden, met substantief nabo, S.-W. njaboto, Tern. njabo);

ngodówo, brandhoutrek; Gal. ngodówo; Tob. ngolówo; Lod. ngodjówo; S.-W. rowo; Tern. howo;

dow'o, rook; Gal. dopo; Tob. loho; Lod. djowo; S.-W. loworo; Tern. njefo; Pagoe njowo;

godóa, tweedejaarstuin ; Gal. godóa ; Tob. golóa ; Lod. godjóa ; S.-W. goróa; Tern. gonjóa ;

dausu, insmeeren; Gal. dahu; Tob. lauhu; Lod. djausu; S.-W. rausu; (Tern. patja);

kodóba, vischarend; Gal. kodóba; Tob. kolóba; Lod. kodjóba; S-W. koréba; Tern. gohéba;

dou, voet; Gal. dohu; Tob. lou; Lod. djou; S-W. rou; Tern. hohu; Pagoe jou; 
todanga, boomenvellen; Gal. toda ; Tob. tolanga ; Lod. todjanga ;

S-W. taranga; (Tern. toti);

tapádu, bedrukken, bezwaren; Gal. tapádu; Tob. tapálu; Lod. tapádju; (S-W. peara; Tern. doda);

edete, grootouders; Gal. ede, grootmoeder; Tob. ele; Lod. edje ;

Pagoe beje; Tern. cre; (S-W. bi'i);

tuudutu, luizen; Gal. tuúdu; Lod. dodudjutu;

De $\mathrm{d}$ in daiti, naald (Gal. jaiti; Lod. djaiti) is uit het Mal. djahit, naaien en valt hier dus buiten beschouwing.

Equivalenten :

dutu, eigenaar; Gal. duhútu; Tern. dihútu; overige dialekten als Tab.

$d u d u n u$, rug; Gal. en Tern. $d u d u$; overige dialekten als Tab.; dowóngi, zand, strand; overal gelijk, behalve Lod. S-W. dongi; daene, treffen; Gal. en Tern. dahe; overige dialekten als Tab.; bidoso, sirih; andere dialekten bido, behalve Tob. bidoho; daluku, arensap; Gal. dalu; Tob. en Lod. als Tab.; Mod. dalu'u; S-W. tjadu'u; (Tern. lahang);

adono, bereiken; Gal. ado; Tob. en Lod. als Tab.; S-W. ngadolo; Tern. kado $(k a+a d o)$;

damáa, wachten; Gal. damáha; Tob. en Lod. als Tab.; S-W. totóma; Tern. domáha;

dia, mes; Gal. diha; overige dialekten als Tab. behalve Tern. dari

diiomono, bejaarde; Gal. dihímo; Tob. en Lod. dimono; dangono, kleinkind; Gal. en Tern. dano; overige dialekten danongo.

Verder wordt nog opgemerkt, dat de $\mathrm{d}$ als aanvanger der nominale vormen naast de verbale vormen met $\mathrm{t}$ tot dezelfde soort behoort. $\mathrm{n}$ is gelijk aan de maleische:

nanere, droomen; ngununu, neus; nonáko, teeken; sano, vragen; naoko, visch; nonu, volgen; munika, enkele; namoro, vogel; nané, dit hier; ncéna, dit.

Voor de verwisseling van $\mathrm{n}$ met $\mathrm{ng}$ zie onder $\mathrm{ng}$.

s supradentale sibilant, gelijk aan de maleische:

sesara, bezem; sasáwi, klapperdop; meseoso, rib ; sosóro, kwal; sisika, doorn; orese, schreeuwen; sosuloko, gezant; tarusu, donker-worden; omasa, ademen; siri, pijn, zeer, ziek. 


\section{Labialen.}

p gelijk aan die in het Maleisch:

ponoko, betooveren; papadecke, kikvorsch; popérvi, zeepschors; pupuongo, scheen; papádi, steunstok voor oudjes; tapu, anker; piloko, blind; poa, storten; supu, naar buiten gaan; pumusu, verzadigd.

De in het Tern. voorkomende $f$ wordt in het Tab. niet aangetroffen, uitgezonderd in de uit het Tern. overgenomen woorden. Waar het Tern. een $f$ heeft, vertoont het Tab. regelmatig $w$ en slechts in enkele gevallen p. De Tern. $f$ is trouwens een klank van latere ontwikkeling, waarschijnlijk is zij in de eerste plaats uit $p$ ontstaan. In het Gal. vertoont zich $\mathrm{p}$ waar het Tern. $\mathrm{f}$ heeft. Het karakter der Tab. w is van dien aard, dat wij ook dezen klank als niet oorspronkelijk moeten beschouwen. Waar dus het Tab. w heeft, naast Tern. f, daar beteekent dit niet, dat de eene klank regelrecht uit den anderen is ontstaan, zoodat dus de gevallen, waar het Tab. $p$ naast het Tern. $f$ heeft, wel op een oorspronkelijker vorm kunnen wijzen. Het blijft evenwel mooglijk, dat de Tab. w, waar zij met de Tern. $f$ afwisselt, uit $f$ is ontstaan.

\section{Voorbeelden :}

Tab. ngowaka, kind; Tern. ngofa; Gal. ngopa; (Tob. ngohaka; Tob. [zuid] ngofaka; Lod. ngozvaka; S.-W. ngozva'a);

Tab. woa, huis; Tern. fala; Gal. pola (rijstschuur); (Lod. wola; S.-W. wala; Mod. woa; Pag. wola);

Tab. tuwongere, acht; Tern. tofkange; Gal. tupaánge; (Tob. tuhánge; S.-W. tu'angere; Mod. tuangele; Pag. tuánge);

Tab. sowoko, vrucht; Tern. sofo; Gal. sopo; (Tob. hohoko; Lod. sowoko; S.-W. sowo'o; Mod. howo'o; Pag. sowok);

Tab. wukunu, verkoopen; Tern. fuku; Gal. (siidja); (Tob. hukunu; Lod. zөикunu; S.-W. zөı'unu; Mod. hu'unu; Pag. ukunu);

Tab. gitiwiri, nagel, hoef; Tern. golotijifi Gal. gitipi; (Tob. gitihiri; Lod. gitiwiri; S.-W. gitjizwidi; Mod. gitizerli; Pag. gitizil);

Tab. diwanga, uitspansel; Tern. tufa; Gal. dipa ; (Tob. dihanga; Lod. diwama; S.-W. en Mod. diwanga; Pag. liwanga);

Tab. wwa, vetatief ; Tern. afa; Gal. upa; (Tob. uha; Lod. uwa ; S.-W. aw'a); 
Tab. wizvisi, zuigen; Tern. fifi; Gal. pipi; (Tob. hihihi; Mod. als Tob.; Lod. als Tab.; S.-W. wowisi; Pag. wizvis);

Tab. ngawoko, tepel; Tern. ngafo; Gal. ngapo; (Lod. ngawoko; S.-W. wawo'o);

Tab. walusu, antwoorden; Tern. fadu; Gal. palu; (Tob. en Mod. haluhu; Lod. walusu; Pag. walus; S.-W. wadusu); Tab. dowanga, aanelkaar hechten; Tern. dofa; Gal. dopa; (Tob. dohanga; Lod. dowama; S.-W. dozvanga);

Tab. kakáwo, asch; (Tern. fika); Gal. gaápo; (Tob. kafo; Lod. kawo; Mod. a'áwo);

Tab. liwanga, gong; (Tern. sarági); Gal. lipa; (Tob. lihanga; Mod. en Lod. liwanga; Pag. salági);

Tab. dowo, rook; Tern. njefo; Gal. dopo; (Tob. loho; Lod. djowo; S.-W. loworo; Pag. njowo);

Tab. sawini, honger-hebben; (Tern. soha); Gal. sapi; (Tob. hahini; Lod. en S.-W. sazvini; Mod. hawini; Pag. sawini); Tab. warasa, maal, keer; (Tern. walo); Gal. para; (Lod. warasa; Tob. hara);

Tab. duwaka, houden van; Gal. dupa;

Tab. izeriti, slijpen; Tern. ifi; Lod. izwiti;

Tab. gowo, zich het haar wasschen; Gal. gopo;

Tab. werve, oom (moeders broer); Gal. en Lod. epe; Pag. pepe; Tab. towo, grootbrengen; Tern. tofo; Gal. topo; Tob. tofo; Lod. en Mod. towo; Pag. towono;

Tab. aworo, canarium decumanum Gaertn. ; Tern. hafo ; Gal. hapo ; Tab. wisa, schaamtegordel (van boomschors); Gal. pisa; Tob. hiha; Lod. en S.-W. wisa;

Tab. wowa, zuigeling; Tern. ngofa, kind; Gal. popa;

Tab. taweke, vogelnest in een boomuitholling; Gal. tapc;

Tab. dawongo, in ontvangst nemen; Gal. dapo;

Tab. dizvizviri, gedreun; Gal. dipipi;

Tab. tawanono, vermanen, waarschuwen; Gal. tapáno;

Tab. sasázi, kokosdop; Tern. tjafi.

e w wordt in de volgende woorden niet gehoord: gatu(w) uku = gatuuku, vleugel; Gal. golupúpu; Tob. gahúhu; Lod. gugútu; S.-W. galatúu; Mod. ga'atúu; Pag. galatóu; $d a(w) u r u=d a u r u$, vrouw van ouderen broer; Tern. tafu; Gal.dapu (jongere schoonzuster van den man); Tob. dahuru; Lod. dauru; S.-W. dau; 
$o(w) u n u=o u n u$, bij; Tern. ofu; Gal. hopu; Tob. ohungu; $g u u(w) u r u=g u u r u$, vlieg; Tern. gufu; Gal. guúpu; Tob. guhuru;

$t u(w) u k u=t u u k u$, schieten, branden; Gal. tupu; Tob. $t u h u k u$;

Lod. tupuku; Mod. tuhu'u; Pag. tuuk; Tern. tabu;

$t u(w) u s u=t u u s u$, loskoopen; Tern. tufu; Gal. tupu; Lod. tupuku; S.-W. tuusu;

$s a(w) u=s a u$, bergbeklimmen tot den top; Gal. sapu;

$u(w)$ ere $=$ uere, vlechten; Tern. ufe; Gal. ngupe;

$r u(w) u t u=r u u t u$, oogensluiten; Tern. rufu.

Van de afwisseling van $p$ en $f$ zijn enkele voorbeelden:

parene, bestijgen; Tern. fane, opkomen van zon en maan, en pane, bestijgen; Gal. pane;

po, subjectspron. 1e pers.mv.incl. ; Tern. fo; Gal. po; S.-W. wo; iwanga, plank; Tern. if $a$; Gal. if $a$;

ponata, nok; Tern. fana; Gal. pona; Lod. wonata; S.-W. wanata;

kipirini, dik (van voorwerpen); Tern. kofiri; Gal. kipiri;

paiti, graven; Tern. fai; Gal. puáe.

$\mathrm{b}$ is gelijk aan die in het Maleisch:

bcbelćta, sagodissel; bobili, schelparmband; babangene, wisselwoord voor hoofdkussen; bibilata, wen, wrat; bubusuku, verband, bindsel; $a b a$, vader; $e b e$, sirihdoosje; boōto, recht; bobosono, pamali, tabu; butuese, brak.

Een enkele maal vertoont het Tab. $\mathrm{b}$ tegen het Tern. $\mathbf{f}$, zooals in biranga, Tern. fira, Gal. bira (overige talen alle biranga), zuster van den broer; beno, Tern. feno, Gal. als Tern. en overige talen beno, behalve S.-W. elo.

$\mathrm{m}$ als de $\mathrm{m}$ in het Maleisch:

mumuku, schedel ; giama, hand; togumu, ophouden ; manoko, groote vleermuis; amo, broodboom; mia, aap; laagomo, grootsch; somóa, ander; amaka, bamboetafel; wosama, binnengaan; taromo, zwart.

De $m$ treedt een enkele maal op als sluiter in overgenomen woorden, die oorspronkelijk in $\mathrm{ng}$ eindigen. 


\section{Voorbeelden :}

utumu, voorspoed, geluk; Mal. oentoeng; sarumu, scheede van een mes; Mal. saroeng.

Hier is de keuze der $m$ toe te schrijven aan den invloed van den voorafgaanden labialen klinker $u$, welke ook tevens de klinker is, waarmee de oorspronkelijke sluiter sonoor wordt gemaakt.

f komt in oorspronkelijke Tab. woorden niet voor. De woorden met $f$ zijn alle aan het Tern. ontleend. De Tabaroe spreken de $f$ evenwel gemakkelijk uit.

figu, vingerhoed; foríki, draaien, ook: liegen; fara, soort, ook moedervlek; fato, naast elkaar rangschikken; folói, meer, meerder ; fero, groeien ; fangu, betalen ; falo, opscheppen ; fefe, e.s.v. paarlemoerschelp; fadja, smerig, vies; gofóla, wandluis (Tern. dofóla).

\section{Alveolaren.}

De tj en de dj worden hier alveolaren genoemd, omdat zij met den punt der tong tegen de alveolaren worden uitgesproken. De plaats der uitspraak is dus een lagere dan bij de echte palatalen.

Voorbeelden :

tjuku-tjuku, kietelen; tjatjáki, kalkpotje; tjedeke, bah! tjiutjiu, piepen van kuikens; tjumu-tjumu, raadsel; tjaana, duizend; tjaána, broek; kalabétju, sarong door de beenen halen en van achteren insteken; tjobo, toegrijpen om te verwonden of te dooden; tjanga, zeerooven; tjetjeretjetje, gekscherende uitdrukking voor bevuilen, bepissen enz. (vgl. Mal. tjeret, spuitachtige ontlasting); tjotjóro, trechter (Mal. tjorong); ratji, vergift (Mal. ratjoen); tjakaíba, masker (uit Tern.); tjafarune, liederlijk (uit Tern.).

Het is vrijwel onzeker of de tj oorspronkelijk tot de klanken behoort, welke het Tab. eigen zijn. Het aantal woorden, waarin deze klank voorkomt, is niet groot en van verscheidene is het zeker, dat zij overgenomen zijn. Evenwel hebben de Tabaroe niet de minste moeite de tj uit te spreken, zoodat zij deze in overgenomen woorden steeds handhaven. Hieruit volgt dus, dat de tj min of meer burgerrecht gekregen heeft in het klankstelsel van het Tab.

Hier volgen een aantal voorbeelden, waarbij niet die woorden zijn genoemd, welker vreemde afkomst vaststaat: 
$u t j a$, wisselwoord voor boki, kat, uit $u s a$, vgl. Tern. tusa (vergelijk beneden de neiging der kinderen om de $s$ tot tj te maken); gurátji, goud, vgl. guráti, curcuma; tjotjátu, geschenk van meerderen aan minderen, stam: tjatu, geven, schenken (Tern. idem; vgl. Mal. mentjatoe, bij kleine gedeelten toedeelen); tjooungu, heerendiensten-verrichten, verbale vorm naast djooungu, heer; tjobo, toegrijpen met de volle hand, knijpen, ook: erop-los-gaan, aanvallen; zelden gehoorde verbale vorm naast het veelvuldig gehoorde djobo, opbreken, vertrekken; tjapadaaka (Tab. benedenland: sapáo) rechts en links kakken; tjaana, duizend; Tern. en Gal. tjala; Lod. tjalana; tjabari, geklets, flauwe taal uitkramen, misschien verminking van Mal. chabar of uit tiabar hati, flauwhartig; tjatjakiri, waterpokken, wellicht verbastering van Mal. tjatar air $=\operatorname{tjatja(r)}+$ akere $($ water $)=$ tjatjakiri. (In het Mod. is het tjatjairi, dat het meest met het Mal. tjatja(r)air overeenkomt); tjatjáki, kalkpotje, wellicht door het opheffen van de prenasaleering der $\mathrm{k}$ en het wegvallen van den consonantischen eindsluiter uit Mal. tjangkir, kopje; tjazuáro, knap, wijs, misschien uit Mal. tjara, trant, manier, plus het Tern. waro, weten, kennen; (tjara komt als tara (in tara kogećna, op deze manier, aldus) nog al eens in de spreektaal van het Tab. voor); tjutju, moesje, naam, waarmee kleine kinderen hun moeder aanspreken, verbastering van susu, borsten; vgl. mama, moeder en mama, mamae, borsten. (In de kindertaal wordt de $\mathrm{s}$ meestal tot tj gemaakt, bv. sesara, bezem, tjetjara; sowoko, vrucht, tjow'oko; kaso, hond, tjatjo; bosaka, regen, betjatja; soso, vliegen van gevleugeld gedierte, tjotjo, enz.)

De Tabaroe uit verschillende dorpen spreken elkaar aan met csamói (esa, moeder, + moi, één, $=$ moeder-één $=$ van-éénmoeder). Gekscheerend maken de jongelui er dan wel van ctjamói, welke tj zij dan ook wel in andere woorden, waarin een s voorkomt, laten hooren.

tjanga-tjanga, zeerooven (Tern. idem). Ook dit woord moet uit andere talen zijn overgenomen, daar de Tabaroe (een bergvolk) een woord voor ,,rooven" hebben in ora.

tjaáli in de uitdrukking: tjaáli kogeéna, niet aldus, is waar- 
schijnlijk een verkorting van het Mal. ketjoeali, uitgezonderd, behalve, alleen niet (stam: tjoeal, uitzonderen, uitsparen).

Hoewel het vrijwel zeker is, dat bovengenoemde woorden niet tot den oorspronkelijken woordenschat van het Tab. behooren, worden deze door de Tabaroe beschouwd als tot hun eigen taal te behooren. Eenige uitroepen en klanknabootsende woorden hebben eveneens de tj, nl.:

tja-tja! wel, wel! tjei! foei! tjedeke! bah!

tjio-tjiono voor titingoono, erg klein; ratjanga, scheuren; karatjongo, krabben met de nagels, zoodat het krast. Als tusschenwerpsels en klanknabootsing staan deze woorden weliswaar buiten de eigenlijke klankwetten der taal.

Slechts enkele voorbeelden zijn aan te wijzen, dat zich in overgenomen woorden een $s$ of $t$ vertoont, waar oorspronkelijk een $t j$ voorkomt :

gesewata, vlot, uit Tern. gutjefa;

sasáwi, klapperdop, uit Tern. tjafi;

tomara, hals, uit Tern. tjama; S.-W. tjamala;

tokata, booze geest, uit Tern. tjaka; S.-W. tja'ata;

tarúpa, sandalen van bladscheede, uit Mal. Port. tjarpoe;

takoro, kloppen, uit Tern. tjako;

bobootara, fabelachtige inktvisch, uit Tern. boboótja;

$u t i$, afdalen, uit Tern. utji; enz.

Over de dj.

Wanneer men de uit het Mal. overgenomen woorden uitzondert, welke in het Tab. zijn opgenomen, dan blijft er slechts een gering aantal woorden over, van welke het moeilijk is uit te maken of zij inderdaad oorspronkelijk tot het Tab. behooren of niet. Bijna al deze woorden komen n.l. eveneens in het Tern. voor en hebben in deze taal ook de $\mathrm{dj}$. Men kan daarom moeilijk verder gaan dan tot deze gevolgtrekking: de $\mathrm{dj}$ is in het Tab. evenals de tj een klank, die zich van buitenaf heeft ingedrongen en die reeds het burgerrecht heeft verkregen, want iedere Tabaroe spreekt de dj correct en gemakkelijk uit. Nergens wordt zij vervangen door een klank, die voor de sprekers dezer taal gemakkelijker is.

Voorbeelden :

$i d j a$, prijs, waarde; Tern. idem; ngadje-ngadje, volksverhaal; 
Tern. wadje, spreken; djodjo, oom; Tern. id.; djui, parkiet, klanknabootsend woord; djuangana, groote prauw; Tern. djuánga; djooungu, heer; Tern. djoóu en djou; djanga, schitteren; Tern. id.; djame, lekker van smaak (Tern. saki), waarschijnlijk klanknabootsing, (vgl. Tab. momámi, zoetigheid van Tern. mami, zoet; ook nog Tab. ame, ruiken, kussen, Tern. hame); djodjáru, maagd, Tern. id.; djongútu, slaapmatje; Tern. id. ; djudju, geweerladen; Tern. id.; djai-djai, zeer snel; Tern. id. staat voor Tab. tai-taiti; djara, paard, uit Jav. djaran; djobo, weggaan, grondwoord tjobo, eroplos-gaan; djalu-djalu, sesuvium portulacastrum L.; djobúbu, bron; Tern. id.; djodjongo, paarlschelp; Tern. id.

Over de nj.

De nj is geen oorspronkelijk Tab. klank. $\mathrm{Z}_{\mathrm{ij}}$ komt slechts in enkele woorden voor, die uit het Tern. en Mal. zijn overgenomen. De eenige beschikbare voorbeelden zijn:

njiara, kanari-boom en -vrucht; Tern. njiha; Gal. niha; njianjiara, merg, (reduplicatie, anduidende overeenkomst met den inhoud der kanarivrucht); njemo, praten, overleggen; Tern. id. Het Tab. heeft in den vorm van temo het meest gebruikelijke woord voor zeggen, welke vorm volgens de thans geldende wetten daaruit niet kan ontstaan zijn; njira, oudere, oudste; Tern. id.; njonjie, wisselwoord voor sizwara, waar de zon schijnt, opgaat $=$ oosten, uit Tern. ; njare, koraalrif, in njare ma ingiri, uiteinde van een koraalrif, uit Tern.; njoa, rog, Tern.; hunja, versiering, uit Tern.; njao, miauwen, klanknabootsing.

Daar geen andere voorbeelden meer bekend zijn, is de gevolgtrekking gerechtvaardigd, dat de $\mathrm{nj}$ in nog sterker mate dan de $\mathrm{tj}$ en dj oorspronkelijk een vreemde klank is in het Tab., doch dat zij, evenals de $\mathrm{tj}$ en $\mathrm{dj}$ zich in de taal begint in te dringen. De omliggende talen (Saoesch-Waiolisch) bezitten de nj wel en de uitspraak daarvan is ook voor de Tab. gemakkelijk, vandaar dat vreemde woorden met $\mathrm{nj}$ onveranderd worden opgenomen.

Uit het Mal. nog enkele voorbeelden:

njaz'a, mensch; alle aanverwante talen hebben njawa, behalve Tern. mantjía, uit Mal. manoesia; Siłoesch ngowa'a, dat ook 
„kind” beteekent (vgl. de Mol. Maleische gewoonte van spreken: anak Ambon, anak Menado, resp. Ambonnees, Menadonees, inplaats van orang Ambon, enz.); Waiolisch: gïidi, iemand, 'n man (Tern. giki, Tab. gikiri);

njanji, zingen; njafisúu, begeeren, belust zijn, uit Ar. Mal. nafsoe;

manjánji, wierook; Mal. kemenjan, menjan;

panjáke, ziekte; Mal. penjakit.

In enkele woorden vertoont het Tab. $\mathrm{n}$ tegen Tern. nj:

ninizwiti, slijpsteen; Tern. njojifi;

naoko, visch; Tern. njao;

nagi, tiental; Tern. njagi;

nagimi, schuld; Tern. njagi;

nabo, wond (Tab. benedenland); Tern. njabo;

ginira, rechts; Tern. gunjira;

munúka, eenige; Tern. manjíka.

\section{Liquidae.}

1 als de Maleische:

kulu, scheren; lulu, rollen; tilíbu, zwanger; kiloliti, omringen; lilara, rondloopen; ligi, muis; loleoto, haven; kubáli, linksch, onhandig; ilingi, stem; sidele, hangen; gila-gila, doorgaan.

In een aantal woorden is de 1 dikwijls uitgevallen, zoowel aan het begin als in het midden der woorden:

aako, oog; andere talen hebben lako; S.-W. en Mod. la'o; de open a-klank in dit Tab. woord is hieraan toe te schrijven, dat de Tabaroe de uitspraak ako fatsoenshalve vermijden, aangezien dat woord in het Tern. ,penis” beteekent en alleen voorkomt in nguusumu ma ako, de scherpe uitspruitsels van jonge alang-alang);

akeme, vleesch; Gal. lake; Lod. lakeme; Tob. akeme; S.-W. la'eme; Mod. a'eme: Pag. lakem; (Tern. rehe);

aze', garen; Tern. lae; overige talen lazes;

owa, goed; Tern. laha; Gal. loha; Lod. en Pag. loa; S.-W. laa;

Tob. en Mod. oa; Tab. benedenland awa;

aeme, likken; Gal. lade;

atete, blijven haken; Gal. kaláte;

aguru, ijl, wijd-uit-elkaar geplant; Gal. lagı ; 
amoko, groot; Tern. en Gal. lamo; eta, splijten; Gal. leta; het Tab. heeft in ma-leléta, een heel klein stukje, de 1 behouden, doch in ma-éta, beetje, stukje, niet meer;

owa, bamboegeleding; Gal. loa;

obiri, nacht; Gal. lobi $=$ wisselwoord voor putu, nacht; alle andere talen hebben $u t u$ of wutu (Tern. futu behalve S.-W. lobidi en lopidi; Pag. lobili). In lobi, wolk (Gal. id.) heeft het Tab. de 1 gehandhaafd.

oara, hardloopen; Tob. id.; Gal. loda; Lod. djodjara; Wai. lalara; (Tern. firi; Saoesch widi);

odiri, bijten, schrijnen; Tob. id.; Gal. lodi; S.-W. lodjidji;

oranga, takken-afkappen; Gal. lora ;

ouku, water-, kookbamboe; Tern. en Gal. lou; Lod. gilou; S.-W. lou'u; Pag. louk;

wolóa, loszitten; Gal. lola; Tern. wola-wola; Lod. ngola; S.-W. loba-loba; Pag. wola;

gooko, verzoeken; Gal. golo; Lod. goloko; S.-W. golo'o; goa, ondereind, voet; Gal. gola;

gugutu, oksel; Gal. golotúhu; overige talen als Tab. behalve S.-W. gudu'u; koō, omhelzen; Gal. kolólo;

kooromo, omhullen, inpakken; Gal. kolóro;

koana, vorst; Tern. Gal. Lod. Pag. koláno; Tob. koano; S.-W. olana; (uit Jav. kelana, voorvechter);

kapéta, schoppen met den voet; Gal. kalapéta ;

kiooko, inslapen; Gal. kilólo;

maata, koud; Gal. mala; S.-W. malata;

ngooto, zee; Gal. Lod. S.-W. ngoloto; Tern. ngolo; Tob. als Tab;

gasauku, zweet; Gal. galasáhu; Lod. garasauku; Tob. gahauku;

S.-W. galasau'u; Mod. gahau'u; (Tern. doroíngo; Pag. goloingot);

gotoaka, witte kakaktoea; Gal. gotóla; Tern. gatála; S.-W. gatala'a; Pag. gotólak;

djaa, werpnet, uit Mal. djala; andere talen als Mal. booto, af, klaar; Gal. bolo; Lod. boloto;

boōto, recht, staat voor: bolowoto, de 1 en $\mathrm{w}$ uitgevallen $=$

boooto = boōto; Gal. bolówo; S.-W. boloto; Pag. bolot;

mao, voelen, beseffen; Gal. malo; 
mooroko, mondspoelen; Gal. molóro;

bobóo, gewrichten; Gal. bobólo;

boomo, eetbare zeeslak; Gal. bololongo;

gilaongo, slaaf; Gal. gilálo;

gumáa, vischhaak; Gal. gumála ;

pooteke, breken van aardewerk; Gal. polóte;

poa, overschenken, overstorten; Gal. pola;

doa, klimmen; Gal. dola;

toaka, afbreken; Gal. en Tern. tola;

toómu, bijeenkomen; Gal. tolómu; Tern. polu en lomu;

tjaana, duizend; Gal. en Tern. tjala;

tjaána, broek; Mal. tjelana;

toolenge, droog van hout enz. Gal. tolóle; Lod. tololenge; (Tern. tore);

saaka, zilver; Gal. en Tern. saláka;

sazvaunu, schild; Gal. en Tern. salawáku;

monaoko, twintig; Gal. monahalo; Lod. monaloko.

In liliaidi, zwaluw, (Gal. totodialiki; Tern. didiái; Lod. guaeli; S.-W. tjiliaidi) is wellicht een opzettelijke verminking aan te nemen, fatsoenshalve aangebracht om de klankgelijkheid met tiliki, schaamdeel (Gal. tili) te vermijden, zooals ook is geschied met mali-mali, vlinder, waarvan de volledige vorm mamaliki in het Gal. den Tabaroe herinnert aan het voor hem aanstootelijke.

Het Gal. woord voor kruidnagel, bululáwa, Tab. buwawanga, is een woord van Maleischen oorsprong, nl. uit boenga lawang. De voorbeelden maeke, beschaamd, (Gal. made; Tob. maleke; Lod. madjeke; S.-W. mara'a; Mod. mae; Pag. maek; Tern. mahe); aeme, likken (Gal. lade; Tob. aleme; Lod. ladjeme) wijzen op het wegvallen eener 1, die waarschijnlijk niet geheel palataal werd uitgesproken, doch een weinig hooger dan de supradentale klanken, dus min of meer alveolaar.

Veel Tab. woorden hebben een 1 tegen die van het S.-W. een d.

Voorbeelden:

tulu, aangaan, aanloopen; tudu;

oluku, niet-willen; odu'u;

ilingi, stem; idingi;

silo, harsfakkel ; sido;

mali, bitter; momádi;

lutu, zinken; dutu;

DI. 84. 
daluku, arensap; djadu'u;

luiti, snijden; duiti;

lingana, overland-gaan; dingana;

zolusu, antwoorden; wadusu;

li, weer, nog; $d i$;

taili, probeeren; taidi;

baili, rest; baidi;

dilikene, geest van een verslagene; didi'ene;

sali, woordwisseling; sadi;

gubáli, links; gubádi;

alu, borstvlakte; $a d u$, enz.

r. De uitspraak van de $r$ is cerebraal, d.w.z. zij wordt gevormd bij het harde gehemelte. Gelijk in alle andere talen, waarin de $r$ voorkomt, zoo worden ook in het Tab. individueele verschillen waargenomen, welke intusschen het bovengezegde niet teniet doen.

\section{Voorbeelden :}

ririkana, vuurhaard (speciaal bestaande uit 3 steenen); rorokutu, twee stukken bamboe of ander materiaal om vuil op te nemen;

gikiri, iemand, mensch, wezen ; koróna, midden; rari, onkruid een weinig wegkappen; ropuku, worstelen; iriki, uitzoeken; resene, uit den weg zetten; ogoro, ophouden, eindigen; dangiri, zit-slaapbank.

In veel woorden, waar het Tab. $r$ heeft, vertoont het $\mathrm{S} . \mathrm{W}$. een $\mathrm{d}$.

Voorbeelden :

ingiri, tand; ingidi;

mokuru, sirih-pruimen; moudu ;

murutu, knorren van beesten; mudutu;

nauru, man; naudu;

$u r u$, mond; $u d u$;

sira, eerst ; sida ;

tuúru, achteraankomen; tuúdu;

peleuru, omwrikken, omhalen; peleudu ;

dungiri, schub; dungidi;

sarimi, pagaai; sadimi;

sirangutu, snot; sidangutu;

wanguru, kies; wangudu; 
dauru, zwagerin; daudu;

airi, mierenkriebel; lalaidi;

iranga, broeder van de zuster; idanga;

ari, weenen; adi;

kakuru, hoog, lang; ka'udu;

souru, medicijn ; soudu ;

nguroto, spier; ngudoto;

gikiri, iemand; gi'idi;

obiri, nacht; lobidi;

iriki, uitzoeken; idi'i;

wariki, opendoen; wadi'i;

diwizwiri, gedreun; diwizidi;

tarusu, donker; tadusu;

gurumini, schaduw ; gudumini;

murúo, hoeveel; mudú;

kurutu, ver; kudutu;

ririkana, haard; didi'ana.

Nog andere woorden hebben in het Tab. r, tegen S.-W. 1.

Voorbeelden :

ngorana, deuropening; ngalana ;

rato, storm; latoro;

uboro, roode kakaktoea; ubolo;

parene, bestijgen; palene;

piakoro, uit-elkaar-doen, vernielen; pia'olo;

poporoso, steenpuist; boboloso;

goróna, middel (lichaam); gólona ;

roese, lichaam; lese;

njiara, kanariboom, -vrucht; njiala ;

sorene, kraaien, niesen; solene;

ratusu, honderd; latusu;

uwere, vlechten; uele;

baoro, boven-, tevoorschijn komen; baolo;

koróna, midden; olóna;

goraka, oprapen; gola'a;

sakara, steken; sakala;

tomara, hals; tjamala;

rio, voetspoor; djilioro;

sosóro, kwal; sosoloro;

rebe, wedden; lebe. 
Ook het Mod. òf Pag., Mod. èn Pag. vertoonen in veel gelijkluidende woorden een 1 , waar het Tab. een $r$ heeft.

Voorbeelden :

\begin{tabular}{|c|c|c|}
\hline $\begin{array}{l}\text { Mod. } \\
\text { (roehe) } \\
\text { hilangut }\end{array}$ & $\begin{array}{l}\text { Pag. } \\
\text { loes }\end{array}$ & $\begin{array}{l}\text { Tab. } \\
\text { roese, lichaam; } \\
\text { sirangutu, snot; }\end{array}$ \\
\hline (toma) & tomal & tomara, hals; \\
\hline ahili & akil & asiri, tong ; \\
\hline halimi & salim & sarimi, pagaai; \\
\hline gitizerili & $\begin{array}{l}\text { gitizeil } \\
\text { ngulot }\end{array}$ & $\begin{array}{l}\text { gitizeiri, nagel; } \\
\text { nguroto, spier; }\end{array}$ \\
\hline $\begin{array}{l}\text { ilanga } \\
\text { lia'a }\end{array}$ & $\begin{array}{l}\text { ilanga } \\
\text { (riak) }\end{array}$ & $\begin{array}{l}\text { iranga, broer v. d. zuster; } \\
\text { riaka, oudere; }\end{array}$ \\
\hline (ronga) & lomang & ronga, naam; \\
\hline o'ele & okel & okere, drinken; \\
\hline ahili & asil & asiri, slikken; \\
\hline gogele & gogel & gogere, zitten; \\
\hline totili & totil & totiri, kind $\mathrm{o} / \mathrm{d}$ arm dragen; \\
\hline ali & $a l i$ & ari, weenen; \\
\hline holene & solen & sorene, niezen; \\
\hline (gomatere) & gomatil & gomatere, medium; \\
\hline $\begin{array}{l}\text { dalingi } \\
\text { (bira) }\end{array}$ & $\begin{array}{l}\text { dangil } \\
\text { bila }\end{array}$ & $\begin{array}{l}\text { dangiri, slaapbank; } \\
\text { bira, rijst; }\end{array}$ \\
\hline naulu & naulu & nauru, man; \\
\hline hila & sila & sira, vroeger; \\
\hline
\end{tabular}

In andere woorden evenwel hebben beide talen de $\mathrm{r}$ behouden:

$\begin{array}{ll}\text { hagarara } & \text { raragar } \\ \text { eri } & \text { geri } \\ \text { faro } & \text { faro } \\ \text { geréhi } & \text { gerési } \\ \text { peréi } i & \text { beréki }\end{array}$

h. De h behoort niet tot het klankstelsel van het Tab. Wel wordt deze klank, waar hij voorkomt in vreemde woorden, welke het Tab. overneemt, bewaard, aangezien de Tabaroes hem zonder moeite uitspreken. De woorden, die een h bevatten, zijn echter van niet-Tab. maar speciaal van Tern. afkomst, al zijn zij in het klankstelsel ingeburgerd.

Voorbeelden :

hisa, omheining; haewúni, beest, uit. Mal.; hunja, versiering; hozvori, zwaard, sabel, wrsch. uit Nederl. houwer; hali, duur (niet uit het Mal. mahal); hari, nettenbreien; lahi, winst, ook: 
verzoeken (voor vragen en verzoeken heeft het Tab. woorden in gaasoko en gooko); kahía, bruinvisch.

Waar de $\mathrm{h}$ in de verwante talen voorkomt, zooals in het Tob. Gal. en Mod., daar is haar equivalent in het Tab. van Tob. en Mod. woorden een s en van Gal. woorden een ledige plaats.

Voorbeelden :

Tob.

houru

wohama

gohomanga

hohe

pehaka

hehehara

hiri

ohiki

hihipouku

hohonotoko

gahauku

arehe

tiohaka

uihi

womaha

orche

ohaka

kaho

korchára

kukihi

gihihi

bohono

hiara

hupu
Tab.

souru, medicijn;

w'osama, binnengaan;

gosomanga, krokodil;

sose, los-, opengaan ;

pesaka, nat;

sesesara, veger, bezem;

siri, pijn ;

osiki, baden;

sisipóku, huishagedis;

sosonotoko, bijtel;

gasauku, zweet;

arese, wit;

tiosaka, schuw, wild;

uisi, stroomen, lekken ;

omasa, ademen;

orese, schreeuwen;

osaka, gekookt;

kaso, hond;

koresára, zuidenwind;

kukisi, bloemknop $\mathrm{v} / \mathrm{d}$ pisang;

gisisi, zaairijst;

bosono, verboden;

siara, aflaten, vieren;

supu, naar-buiten-gaan;

Voorbeelden van Mod. en Tab.

hilangut
hoata
hila
hepi
hoana
huhu
hawen
goaha
howo'o
wuhi
moha
'aho

sirangutu, snot;

soata, vier;

sira, voorheen, eerst;

sepi, schuin;

soana, dorp;

susu, spruit;

sau, bergbeklimmen;

oasa, ondiep van water;

sowoko, vrucht;

z'usi, kammen ;

mosa, sarong;

kaso, hond; 


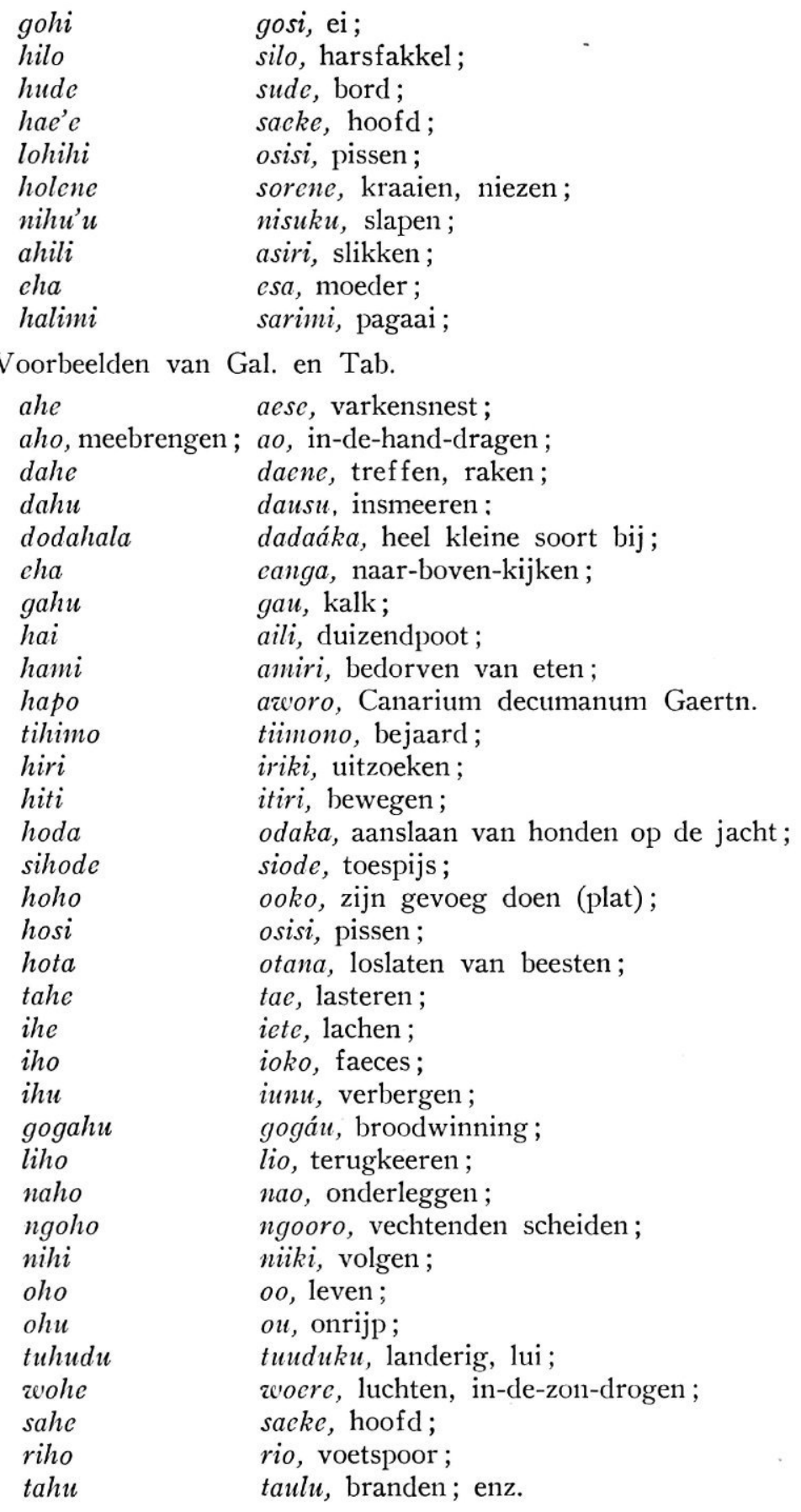


Woordvorming en klemtoon.

Boven is reeds aangetoond, dat het Tab. een vocalische taal is. Elke lettergreep kan worden voorgesteld door een medeklinker met klinker, ook wel door een klinker afzonderlijk. Eveneens is reeds aangetoond, dat tengevolge van den vocalischen aard der taal geen geprenasaleerde medeklinkers worden toegelaten en dat de taal niet alleen zelf niet prenasaleert, doch dat ook de geprenasaleerde klanken in overgenomen woorden weer ontnasaleerd worden (zie voorbeelden op blz. 309 en 310).

De taal is echter niet altijd vocalisch geweest. $\mathrm{Zij}$ heeft consonantische eindsluiters gekend en wel voorzoover thans nog kan worden nagegaan: $k, t, r, s, 1, m, n$, ng. Deze sluiters, die in verwante talen, b.v. in het Gal. en Tern. afvallen, zijn in het Tab. (alsook in het Tob., Lod., S.-W. en Mod.) gespaard gebleven, doordat zij doorklinkend zijn gemaakt, nl. door ze uittespreken met denzelfden klinker als die van de voorafgaandle lettergreep. Alleen het Pag. heeft in veel harer woorden die eindsluiters behouden, doch deze niet sonoor gemaakt.

Op deze wijze ontstaat feitelijk een nieuwe lettergreep uit den oorspronkelijk stommen sliiter, alhoewel deze nieuwe lettergreep nimmer voor vol wordt geteld. Voor het accent nl. rekent zij niet mede. Men kan dus niet zeggen, dat in woorden met klinkend gemaakten sluiter het accent op de derde-lettergreep-van-achteren valt, want de accentueering valt - naar de neiging van het Tab. - op de lettergreep, die de vóórlaatste was, toen de sluiter nog stom was. Het blijkt dus, dat de taal cloor het accent niet te verplaatsen, de nieuw gevormde lettergreep niet voor vol rekent.

Voorbeelden :

Sluiter $\mathrm{k}$ (geworden tot $k a, k c, k i, k o, k u$, al naar den klinker der oorspronkelijk laatste [gesloten] lettergreep) :

a. gakaka, verhemelte, uit gakak, hetwelk het accent op de voorlaatste lettergreep had en welk accent zich in den nieuwen vorm gakaka heeft gehandhaafd; Gal. gaka; Pag. gakak; pclclaka, mager; Pag. pclélak; Gal. pcléla; riaka, oudste kind; Pag. riak; Gal. ria; ngowaka, kind; Pag. ngoak; Gal. ngopa;

e. saeke, hoofd; Gal. sahe; peleke, voetstooten; Gal. pele; toteke, aankloppen; Gal. tote; 
i. osiki, baden; Gal. osi; risiki, tandvleesch; Gal. risi;

iriki, uitzoeken; Gal. hiri;

p. ioko, faeces; Gal. iho;

mogiooko; Gal. mogiówo ; (het Tab. woord staat voor mogiówok); tagoko, vangen; Gal. tago;

u. ngauku, oor; Gal. ngau;

sauku, warm; Gal. sahu; (Tab. staat voor sauk);

tuuduku, landerig; Gal. tuhúdu; (Tab. staat voor tuhúduk);

Voorbeelden van sluiter $\mathrm{t}$ :

a. maata, koud; Gal. mala; (Tab. staat voor malat); soata, vier; Gal. soha; (Tal). staat voor sohat);

tokata, vampyr; Gal. toka;

e. atete, blijven-haken; Gal. kaláte; edcte, grootouders; Gal. cdc, grootmoeder; iete, lachen; Gal. ie ;

i. tiikiti, hoesten; Gal. tiiki; potiti, navel; Gal. woti; puniti, klapperbast; Gal. puni;

o. leoto, in een haven ankeren; Gal. leo; seroto, dakdekken; Gal. scro; pagoto, stank van visch, enz.; Gal. pago;

u. tuudutu, w.w. luizen; Gal. tuídu; tumutu, wijzen; Gal. tumu; murutu, brommen van beesten; Gal. muru;

Sluiter r:

a. kaanara, hoereeren; Gal. kaána ; oara, hardoopen; Gal. loda; saara, slangenhol; Gal. saha;

e. okcre, drinken; Gal. oke; ucre, vlechten; Gal. ngupe; woore, in-de-zon-drogen; Gal. wohe;

i. asiri, slikken; Gal. dasi; ikiri, afvegen; Gal. piki; gitiwiri, nagel; Gal. gitipi;

o. dababoro, door bandjir naar zee afgedreven rommel; Gal. dabábo;

dadakoro, klopper; Gal. dadáko; aworo, kanari-soort; Gal. hapo; 
u. uguru, dij; Gal. ugu;

baduru, ban, schuld vloek; Gal. badu;

souru, medikament; Gal. sou;

\section{Sluiter s :}

a. omasa, ademen; Gal. woma;

warasa, keer, maal; Gal. para;

oasa, ondiep van water; Gal. oa;

e. orese, schreeuwen; Gal. ore;

rocse, lichaam; Gal. rohe;

aese, varkenshol; Gal. ahe;

i. maisi, waarzeggen; Gal. mai; (Mol. Mal. mawi);

isisi, pis; Gal. isi;

zviwisi, zuigen; Gal. pipi;

o. bidoso, sirih; Gal. bido;

baoso, zeestroom; Gal. bawo;

ramoso, uitpersen; Gal. ramo;

u. palusu, antwoorden; Gal. palu;

torusu, verschepen; Gal. toru;

tuusu, loskoopen; Gal. tupu;

Sluiter 1 is zeldzamer dan de andere sluiters:

a. geen voorbeelden bekend.

e. sidele, hangen; equivalenten onbekend.

widcle, Alocasia-soort ; , ,

alclée, tusschenwerpsel;

i. pidili, losgaan; Gal. pidi;

aili, duizendpoot; Gal. hai;

taili, probeeren; Gal. tai;

o. geen voorbeelden bekend.

u. taulu, vuur-aanmaken; Gal. tahu;

kububulu, opborrelen; Gal. kubúbu;

verdere voorbeelden niet aanwezig.

Sluiter m:

a. tedama, kauwen; Gal. teda;

cmama, oom; Gal. cma;

wosama, binnengaan; Gal. wosa;

e. aeme, likken; Gal. lade;

akeme, vleesch; Gal. lakc;

verdere voorbeelden ontbreken. 
i. nagimi, schuld; Gal. nagi;

sarimi, pagaai; Gal. sari;

rikimi, dichtopelkaar; Gal. riki;

o. todomo, scherp, puntig; Gal. todo;

inomo, voedsel; Gal. ino;

taromo, zwart; Gal. taro;

u. dotumu, bet-overgrootouders; Gal. dotu;

nguusumu, alang-alang; Gal. nguúsu;

didumu, bedekken met zand, enz.; Gal. didu;

\section{Sluiter $\mathrm{n}$ :}

a. todokana, schrikken; Gal. todóka;

lemana, voorplecht; Gal. hema;

(ding)irana, stapelen, bij-, opelkaarleggen; Gal. hira;

e. resene, uitwijken; Gal. rese;

sorene, niezen, kraaien; Gal. sore;

morcne, verheugd zijn; Gal. more;

i. sangaini, graaien; Gal. sangáhi;

sawini, hongeren; Gal. sapi;

moroini, mak, tam; Gal. morói;

o. adono, bereiken, aankomen; Gal. ado;

biono, aangezicht; Gal. bio;

mootono, verrot, vergaan; Gal. moóto;

u. akunu, kunnen, vermogen; Gal. aku;

odumu, allen, alles; Gal. ngodu;

ngounu, gehoorzamen; Gal. ngou;

Sluiter ng:

a. liwanga, gong; Gal. liwa ;

roanga, blaffen; Gal. roa;

eanga, naar-boven-kijken; Gal. cha;

e. rodenge, rugharen, manen; Gal. rode;

songene, staat voor: sonenge (Lod. sonenge; Tob. honenge;

Gal. sone; Tern. sone);

toolenge, droog; Gal. tolóle;

i. ilingi, stem; Gal. ili;

miringi, gal; Gal. miri;

baingi, verloofde; Gal. bobái;

o. kobongo, been, nerf; Gal. kobo;

tobongo, zwemmen; Gal. tobo;

dawongo, toeloopen; verwelkomen; Gal. dapo ; 
u. tummungu, aandringen om te blijven eten of overnachten; Gal. tийmu;

dudungu, droog; Gal. dudu;

djooungu, heer; Gal. djoóu;

Uit boven gegeven voorbeelden blijkt de neiging van het Tab. om de consonantische eindsluiters te sparen. De vergelijking met het Gal. en het accent toonen duidelijk aan, dat in beide talen de vorm dezer woorden is geweest: gakak, soat, oar, omas, pidil, tedam, resen, liwang, dus tweelettergrepig, met het accent op de voorlaatste lettergreep.

In de meer dan tweelettergrepige woorden, die het Gal. heeft, hetzij die ontstaan zijn door het behouden van den eindsluiter of door woordvorming anderszins, blijft het accent in het Tab. onveranderd; b.v. :

Gal. talaája of talaázı'a, gierig; Tab. talaáa $=$ talaā;

Gal. kolólo, omhelzen; Tab. koóo = koō;

Gal. bobólo, gewrichten; Tab. bobóo;

Gal. gumála, vischhaak; Tab. gumáa;

Gal. kasinánga, spiegel, glas; Tab. kasináa ;

De mediae b, d, g, de h, de tenuis p en de halfklinker w komen niet als sluiters voor. De 1 is in het Tab. als sluiter blijkbaar zeldzaam geweest. In het S.-W., Mod. en Pag. daarentegen zijn daarvan roorbeelden te over (zie blz. 325 en 326).

In enkele uit andere talen overgenomen woorden accentueert het Tab. de voorlaatste vocaal; b.v.: sakisii, getuige; Mal. saksi; sutaráa, zijde; Mal. soctera; sapitúu; Ar. sabtoc, zaterdag, sabbat; kurusii, stoel; Ar. koersi; alimúu (Ar. alim, geleerd); in: awi alimúu de zoi bidaá panakówa, men kan niet (weten) komen achter zijn kennis van tooverijen.

\section{Voorna mwoorden.}

ik: Tab. ngoi; Gal. ngohi; Tob. ngohi; Lod. ngodji; Saoe id; Wai id.; Tern. ngori; Mod. Pag. id.;

jij: Tab. ngona; Gal. id.; Tob. id. ; Lod. id.; Saoe. ngana; Wai. ngana; Tern. ngana; Mod. Pag. id.;

hij : Tab. una; Gal. id.; Tob. unanga; Lod. id.; Saoe id.; Wai. unanga; Tern. id.; Mod. Pag. id.;

zij : Tab. muna; Gal. id.; Tob. munanga; Lod. id.; Saoe. id. ; Wai. munanga; Tern. mina; Mod. Pag. id.; 
wij: Tab. ngone; Gal. id.; Tob. id.; Lod. id.; Saoe. ngene;

Wai. ngene; Tern. ngon(e); Mod. Pag. id. (incl.);

wij: Tab. ngomi; Gal. id. Tob. id.; Lod. id.; Saoe. id.; Wai. id.; Tern. ngom(i); Mod. Pag. id. (excl.);

gij: Tab. ngini; Gal. id.; Tob. id.; Lod. id.; Saoe. id.; Wai. id.; Tern. ngon(i); Mod. Pag. id.;

zij : Tab. ona; Gal. id.; Tob. onanga; Lod. id.; Saoe. ana; Wai. ananga; Tern. ana; Mod. Pag. id.;

(id. wil zeggen: gelijk aan het Tab.)

Uit deze opgave blijkt, dat het pers. vnw. 1e en 2e ps. enkel- en meervoud bestaat uit resp. ngo $+i$ (en varianten $h i, d j i, r i$ ), ngo $+n a ; n g o+n e ; n g o+m i$; ngo $+n i$. Het S.-W. heeft $1 \mathrm{e}$ ps. mv. incl. ngo in $n g e$, alle andere dialekten $2 \mathrm{e}$ ps. mv. ngo in $n g i$ (behalve het Tern.) denzelfden klinker gegeven als die, waarmee de eindsluiter $\mathrm{n}$ doorklinkend is gemaakt. Dit prefix $n g o$ heeft de $3 \mathrm{e}$ ps. enkel- en meerv. niet. Zou het te gewaagd zijn de veronderstelling uit te spreken, dat ngo oorspronkelijk vóór alle, dus ook voor den 3en ps. enk. en mv. gestaan heeft? Het Tob. en Wai. hebben dan dit verwaarloosde ngo nog in een suffix: unanga, munanga, onanga en ananga en welluidendheidshalve tot nga gemaakt en het dus dezelfde vocaal gegeven als van de voorafgaande lettergreep, evenals het Tern. den 2 en ps. enk. tot ngana en het S.-W. den 1en ps. mv. incl. tot ngene en alle andere dialekten den 2 en ps. mv. tot ngini maakten, behalve het Tern. dat ngoni heeft. Immers het Tab. heeft nog in ngomuna (vocativus) een woord, waarmee een man zijn vrouw aanspreekt. Het heeft er veel van alsof dit ngo aan het woord, waarbij het gevoegd is, een zekere waardigheid of aanzien moet geven, ten eerste aan de persoonlijke voornaamwoorden, ten andere aan de woorden vrouv, dochter, tante en vrouwelijke eigennamen. Dat ngo niet (meer) in den 3en ps. enk. en mv. voorkomt, is misschien hieraan toe te schrijven, dat dit altijd gevallen zijn w'aarover of waarvan men spreekt. Tegenover meerderen gebruikt de Ternataan nooit ngori, doch steeds fangare (mannelijk) en fadjaru (vrouwelijk), welke woorden in beteekenis overeenkomen met het Mal. hamba. Het Tab. heeft ngodjodjo en ngoowa, schoonmoeder van de vrouw; ngoeme, moeder (Lod. ngedje ngo + edje) welke woorden in de vocativus van ngo ontdaan worden, nl. djodjo, owa, eme (Lod. ina, cdje). Voorts heeft het Tob. bij alle bezitt. vnw., wanneer er van vrouw, dochter, zuster enz. sprake is, dit ngo als 
prefix : ahi, mijn, wordt: ngo $+a h i=n g o h i ; n i$, uw, wordt $: n g o$ $+n i=n g o n i ; a i$, zijn, wordt: ngo $+a i=n g o i ; n a n g a$, onze (incl.), wordt: ngo + nanga $=$ ngonanga $;$ mia, onze (excl.), wordt: ngo + mia $=$ ngomia $;$ manga, hun, wordt $:$ ngo + manga $=$ ngomanga. Het Gal. heeft deze eigenaardigheid alleen in den 1en en 2en ps. enk. $a i$, mijn, wordt: ngo $+a i=n g o i$; ani, uw, wordt: ngo + ani = ngoni. Het woord „vrouw” (geslachtsnaam) en „vrouwelijk” heeft in alle dialekten dit prefix ngo. Tab. ngeweka (waarin de vocaal $o$ in $n g o$ gelijkluidend gemaakt is met de daaropvolgende vocaal $e$, die den klemtoon heeft; zie blz. 312 over het ontstaan van wekata); Gal. ngopedéka; Lod. ngowedjéka; Tob. ngohéka; Tern. fofohéka; Mod. ngowéa; Pag. als Tab. Dit prefix ngo verdwijnt in het woord „vrouw” (echtgenoote): Tab. en Pag. wekata; Gal. pedéka; Lod. wedjéka; Tob. hekata; Tern. fohéka; Mod. we'ata. Zou dit prefix ngo wellicht hetzelfde zijn als in ngowaka, kind? Lod. als Tab.; Gal. ngopa; Tern. ngofa; Tob. (zuid) ngofaka; Tob. ngohaka; Mod. ngoa'a; Pag. ngoak; W. ngowa'a; S. ngowa'. Zoo ja, dan is dat eerste bestanddeel van ngo (waka, - $p a$, $-f a$, enz.) een vaste verbinding geworden in woorden, die het vrouwelijk geslacht aanduiden. Mooglijk dat dan de Tern. woorden fangare en fadjaru (ik, resp. mannel. en vrouwel. tegenover meerderen) het tweede bestanddeel van ngofa $(=f a)$ behouden hebben, terwijl het Tern. woord ngongáre, jongeling, weer het eerste bestanddeel vertoont. Wellicht dat oorspronkelijk ook de woorden voor „man” en ,mannelijk" dit eerste bestanddeel ngo als prefix gehad hebben, dat dan tot $n$ geworden is (nau, nauru, naudu; het Tab. heeft dit nog in ngauru, [grondwrd. nauru] ,vruchtzetten” van rijst).

Ter verduidelijking voor de veronderstelling, dat ngo een bestanddeel is van ngoreaka (en varianten), zij opgemerkt, dat de Tabaroes op de vraag: „Van welk geslacht is dit kind?”, niet antwoorden : o ngowaka o ngewéka of : o ngowaka o nauru (een kindvrouw $=$ meisje; een kind-man $=$ jongen) doch: o ngewéka, of : $o$ nauru (vrouw $=$ meisje; $\operatorname{man}=$ jongen). Het woord ngowaka, kind, wordt hierbij dus verzwegen, alsof dit reeds in den geslachtnaam ware opgenomen. Voor de uitdrukking ,kinderen” in den zin van het Nederl. „schoolkinderen”, „dorpskinderen”, enz. gebruikt het Tab. niet het woord ngoreaka (kind, kinderen), doch njawa (mensch) en zegt dus niet o sikóla ma ngowaka, schoolkinderen, doch: o sikóla ma njazva, schoolmenschen. Alleen wordt ngowaka gebruikt in den zin van ,geslacht”, ,afstamming”, welk woord, indien men 
daarmee de nakomelingschap wil aanduiden, geredupliceerd wordt tot ngowa-ngowaka. Nog zij opgemerkt, dat het Saoesch ngowa'a heeft in: o Waiolitji ma ngowa'a, de Waioliërs; o Woláda ma ngow'a'a, de Hollanders, zooals men in de Molukken gewoon is te zeggen: anak Ambon, Ambonneezen, enz., waarvoor het Tab. evenwel heeft verkort: o Abongóka, Ambonneezen, of volledig: o Abongóka ma njawa.

Uit de combinatie van plaatsaanduidende woorden en aanwijzende vnww. met den 3 en ps. enk. en mv. valt nog op te merken, dat in het Tab. de $3 \mathrm{e}$ ps. enk. en mv. una, muna en ona herleid worden tot resp. $u, m u$, en $o, \mathrm{nl}$. in $u n a+$ aanw. vnw.; $n \mathcal{e}$ (verk. van neéna) + prefix be tot bene + una $=$ benuúna, verkort: benúu. Aldus ook: benumúu en benóo. Waaruit de gevolgtrekking te maken is, dat deze pers. vnww. te herleiden zijn tot resp. $u$, $m u$ en $o$. De volledige vorm van den 3 en ps. mannel. enk. una is waarschijnlijk oorspronkelijk zunna geweest, want bij de vervoeging der werkww. heeft het subjectspronomen van una in wo de w nog behouden, gelijk het subjectspronomen van muna in mo de $\mathrm{m}$ nog heeft. Alleen het Lod., $\mathrm{S}$.-W. en Tern. hebben ook de $\mathrm{w}$ in genoemd subj. pron. verloren: una otagi, hij gaat; terwijl het Tab. Gal. Tob. Mod. en Pag. hebben: una wotagi.

De persoonlijke voornaamwoorden zijn dus te herleiden tot:

\section{Enkelvoud.}

1e ps. (ngo-) i (-hi, -dji, -ri); $\quad$ 3e ps. mnl. (w) u (-na, -nanga); 2e ps. (ngo-) na; 3e ps. vrl. mu (-na, -nanga).

Meervoud.

1e ps. incl. (ngo- nge-) ne; 2 2e ps. (ngo- ngi-) ni ; le ps. excl. (ngo-) mi; $\quad$ 3e ps. o (-na, -nanga).

Deze zelfde pers. vnww. worden teruggevonden als object bij de vervoeging, waarbij dan de $\mathrm{i}$ de plaats inneemt van de andere klinkers ter aanduiding van den objectsvorm, waarin zij door de vervoeging van het subjectspronomen gekomen zijn. $\mathrm{Zij}$ worden dan:

Enkelvoud.

1e ps. $i$;

2e ps. $n i$; 3e ps. mnl. wi;

3e ps. vrl. mii. 


\section{Meervoud.}

1e ps. incl. $n a$ (volledige vorm $i n a)$; 2e ps. $n i$;

le ps. excl. $m i$;

3e ps. ki.

(zie voorbeelden van de vervoeging met object blz. 338 v.v.).

De subjectspronomina bij intransitieve vervoeging zijn:

$\begin{array}{ll}\text { to } \mathrm{ik}, & \text { (ngone) po wij, in } \\ \text { no } \mathrm{jij}, & \text { mijo wij, excl. } \\ \text { wo hij, } & \text { nijo gij (lieden). } \\ \text { mo zij, } & \text { jo zij (lieden). }\end{array}$

Voor dieren en zaken (onzijdig) enk. en mv. $i$.

Bij de transitieve vervoeging worden de subjectspronomina to enz. samengesteld met het objectsexponent voor zaken $j a$ tot to $+j a=t a, n a, w a, m a, p a, m i j a, n i j a, j a$ (zie Gal. Leiddraad van M. J. v. Baarda, blz. 61).

$j o$ is een meervoudsteeken (zie voorbeelden verderop); po wordt alleen als meervoud beschouwd, wanneer het voornaamwoord 1e ps. mv. incl. die meervoudsvorm aangeeft; potagi is niet wij gaan, maar de onbepaalde wijs van het werkwoord gaan. Daarentegen: ngone potagi is: wij gaan; posano de posango is: vragen en antwoorden; podoa de pouti is: klimmen en dalen, enz.

Eenigszins dezelfde functie, welke de nadrukkelijke nominatief ngone verricht, heeft ook ona, namelijk wat betreft de noodzaaklijkheid om bij de vervoeging met het werkwoord verbonden te blijven, teneinde duidelijkheidshalve aan te toonen, dat het de $3 \mathrm{e}$ pers. meervoud is. Immers heeft ona alleen in het meervoudsteeken $j o$ een exponent, waarmee de vervoeging van het werkwoord plaats heeft. Maar dit jo afzonderlijk gebruikt, kan evengoed een exponent zijn, aangevende een handeling, zoowel door menschen als door dieren verricht; jokigóli, kan zijn: „zij (menschen) bijten hen”, als „zij (beesten) bijten hen”. Nog: jokituduku kan zijn: „zij (menschen) steken hen”, als : „zij (slangen) steken hen”. Evenzoo wanneer jo door transitieve vervoeging met het objectsexponent voor zaken tot $j a$ gevormd wordt, is er zonder nadrukswijzer tusschen de handeling van menschen, dieren en zaken geen onderscheid: jaodomo kan zijn: ,het (kind) eet ' $t$ '; , ,zij (menschen) eten 't' of : ,de (hond) eet 't'. De duidelijkheid eischt dus veelal, dat de nadrukkelijke nominatief ona aangeeft, van welke handeling sprake is.

Om een denkbeeld te geven van de functie der woorden to, no, 
$w o, m o, p o, m i$ en $n i$, welke waarschijnlijk voornaamwoorden zijn, verwijzen wij naar de „Mal. Spraakkunst van prof. van Ophuysen”, Hfdst. 11, waar over de vervoeging der Mal. werkwoorden verwezen wordt naar de oorspronkelijke vervoeging der werkwoorden in het Nederlandsch, welke niet waren: ik zeg, gij zegt, hij (zij) zegt, maar: zegge, zegs, zegt. Prof. v. O. zegt dan, dat die e, s, t, overblijfselen zijn van persoonlijke voornaamwoorden. Iets dergelijks heeft het Tab. (en verwante talen) in to, no, wo, enz., aangezien deze afzonderlijk geen beteekenis hebben en eerst waarde krijgen, wanneer zij in verbinding komen met werkwoorden. De functie, welke to, no, enz. verrichten, kan niet door de zelfstandige vormen der persoonlijke voornaamwoorden ngoi, ngona, una, enz. worden overgenomen, aangezien deze laatste alleen dienst doen als nadrukwijzers, d.w.z. om aan te toonen, dat niet een ander, doch de persoon in kwestie, over wien in den zin sprake is, bedoeld wordt. ngoi isene vormt niet den zin ,ik hoor”, maar wel: toisene is :,ik hoor”. Daarenboven: ngoi toisene is : ,ik (en geen ander) hoor”.

Wij krijgen dus :
poisene, hooren;
toisene, ik hoor (hoore);
noisene, jij hoort (hoors);
woisene, hij hoort (hoort);
moisene, zij hoort (hoort);
iisene, het hoort (hoort);
mijoisene, wij (excl.) hooren;
nijoisene, gij (lieden) hoort;
joisene, zij (lieden) hooren ;
iisene, zij (dieren) hooren.

Met den nadrukkelijken nominatief ngone is poisene (dus: ngone poisene) de inclusieve vorm voor: wij hooren.

$$
* * *
$$

Voorbelden van de vervoeging met object:

1e ps. enk. :

tomapaasana, ik mij sla;

tonipaasana, ik u (je) sla;

towipaasana, ik hem sla;

tomipaasana, ik haar sla;

tapaasana, ik het sla; 
tinipaasana, *) ik u (lieden) sla;

tokipaasana, ik hen (enkelen) sla;

takipaasana, ik hen (allen) sla;

tapaasana, ik ze sla;

*) De o van de subj. pronomina enkelvoud verandert in $i$ ter aanduiding van het meervoud, wanneer zij den 2 en ps. mv. tot object hebben.

2e ps. enk. :

noipaasana, gij mij slaat;

nomapaasana, gij u slaat;

1) wonipaasana, gij hem slaat (regelmatig nowi-);

2) monipaasana, gij haar slaat (regelmatig nomi-);

napaasana, gij het slaat;

3) minipaasana, gij ons (excl.) slaat (regelmatig nomi-);

nokipaasana, gij hen (enkelen) slaat;

nakipaasana, gij hen (allen) slaat;

napaasana, gij ze slaat;

3e ps. mnl. enk. :

woipaasana, hij mij slaat;

wonipaasana, hij u slaat;

womapaasana, hij zich slaat;

wipaasana, hij hem slaat $(w i=w o+w i)$;

womipaasana, hij haar slaat;

wapaasana, hij het slaat;

wonapaasana, hij ons (incl.) slaat;

womipaasana, hij ons (excl.) slaat;

winipaasana, hij ulieden slaat;

wokipaasana, hij hen (enkelen) slaat;

wakipaasana, hij hen (allen) slaat;

wapaasana, hij ze slaat;

3e ps. vrl. enk. :

moipaasana, zij mij slaat;

monipaasana, zij u slaat;

momapaasana, zij zich slaat;

4) womipaasana, zij hem slaat (regelm. mowi-);

4) mipaasana, zij hem slaat (regelm. mowi-);

mipaasana, zij haar slaat $(m i=m o+m i)$;

mapaasana, zij het slaat;

monapaasana, zij ons (incl.) slaat;

Dl. 84. 
momipaasana, zij ons (excl.) slaat:

minipaasana, zij ulieden slaat;

mokipaasana, zij hen (enkelen) slaat;

makipaasana, zij hen (allen) slaat;

mapaasana, zij ze slaat;

1e ps. meerv. incl.:

ngone powipaasana, wij hem slaan;

ngone pomipaasana, wij haar slaan;

ngone papaasana, wij het slaan;

ngone pomapaasana, wij ons slaan;

ngone pokipaasana, wij hen (enkelen) slaan:

ngone pakipaasana, wij hen (allen) slaan;

ngone papaasana, wij ze slaan;

1e ps. meerv. excl.:

minipaasana, wij u slaan;

miruipaasana, wij hem slaan;

mimipaasana, wij haar slaan;

mijapaasana, wij het slaan;

mimapaasana, wij ons (enkelen) slaan;

mijomapaasana, wij ons (velen) slaan;

minipaasana, wij ulieden slaan;

mijokipaasana, wij hen (enkelen) slaan;

mijakipaasana, wij hen (allen) slaan;

mijapaasana, wij ze slaan;

2e ps. meerv. :

nïpaasana, gij mij slaat $(n \ddot{i}=n i+i)$;

5) winipaasana, gij hem slaat (regelm. niwi-);

minipaasana, gij haar slaat (regelm. nimi-);

nijapaasana, gij het slaat;

minipaasana, gij ons (excl.) slaat (regelm. nimi-);

nimapaasana, gij u (enkelen) slaat;

nijomapaasana, gij $\mathrm{u}$ (velen) slaat;

nijokipaasana, gij hen (enkelen) slaat;

nijakipaasana, gij hen (allen) slaat;

nijapaasana, gij ze slaat;

3e ps. meerv. :

ona ipaasana, zij (enkelen) mij slaan;

ona joipaasana, zij (velen) mij slaan; 


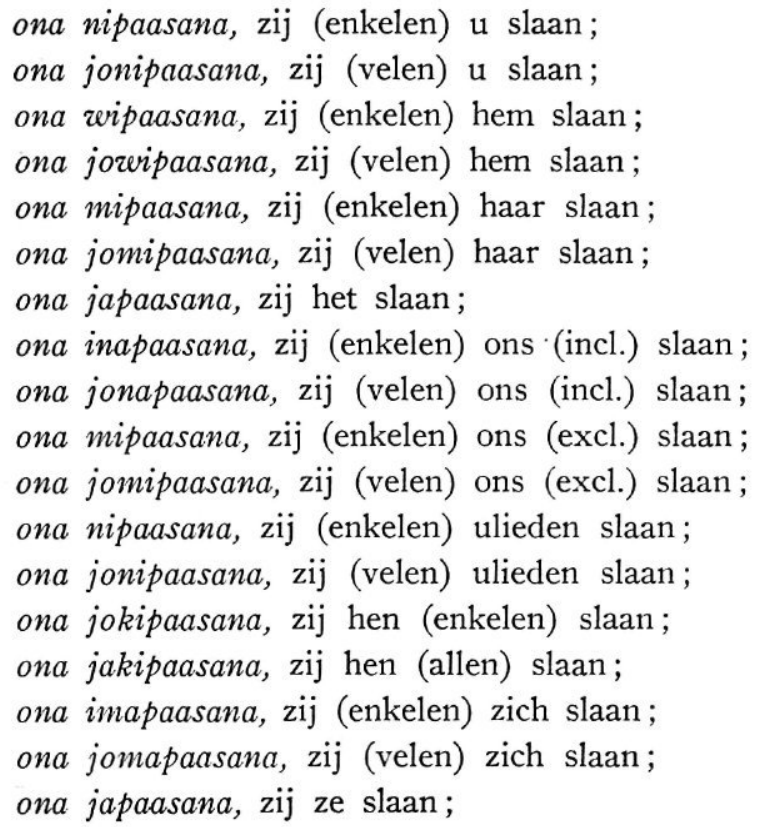

De onregelmatige vormen:

1) wonipaasana, gij hem slaat; regelmatig: nowi-, is saamgetrokken tot $n o+w i=n i$, terwijl de daardoor verloren gegane $w$ ' weer hersteld wordt in wo, dus: woni hij, jij 'm (hem). B.v. de vorm met nadrukswijzer: ngona woniasokino, jij, hij, jij 'm roep hierheen!

2) monipaasana, gij haar slaat; regelmatig: nomi-, is saamgetrokken tot $m o+n i=n i$. De verloren $m$ wordt hersteld in $m o$, dus: moni, zij jij 'r (haar). B.v. de vorm met nadrukswijzer: ngona monikúla, jij, zij, jij 'r geeft.

3) minipaasana, gij ons (excl.) slaat; regelmatig: nomi-, saamgetrokken tot $n o+m i=n i$. De verloren $m$ wordt in $m i$ hersteld, dus: mini, ons, jij ons. B.v. met nadrukswijzer: ngona minisano, $\mathrm{jij}$, ons, jij ons vraagt.

4) Twee vormen, ten eerste de zelden gehoorde vorm:

womipaasana, zij hem slaat; regelmatig: mozvi-, saamgetrokken tot $m o+w i=m i$. De verloren $w$ wordt hersteld in $w o$, dus: $w o m i$, hij, zij 'm. B.v. met nadrukswijzer: muna z'omisihaga-haga, zij, hij, zij 'm voor den gek houdt.

Ten andere de meer gebruikte vorm:

mipaasana, zij hem slaat; regelmatig: morvi-, saamgetrokken tot $m o+w i=m i$. B.v. met nadrukswijzer: muna misingoz'aka, zij, 
zij 'm (hem) baart. De eerstgenoemde vorm wordt dàn gebruikt, wanneer er verwarring zou kunnen ontstaan met den gelijkluidenden vorm mipaasana, zij slaat haar.

5) winipaasana, regelmatig niwi-, is saamgetrokken tot $n i+w i$ $=n i$. De verloren $w$ wordt in $w i$ hersteld,, dus : $w i n i$, hij, gijlieden 'm. B.v. met nadrukswijzer: ngini winitagoko, gijlieden, hij, gij 'm pakt. Een andere verklaring van de vormen woni, moni, mini, womi en wini zou gevonden kunnen worden in de mooglijkheid, dat een omzetting der medeklinkers heeft plaats gehad uit resp. nowi, nomi, nomi, mowi en niwi.

Een eigenaardigheid van het Tab. is, dat de o van alle subjectspronomina, waar zij den 3 en ps. meerv. tot object hebben in collectieve beteekenis (b.v. alle inwoners van een dorp, enz.) verandert in $a$.

Voorbeelden :

tokiasoko, ik hen (enkelen) roep; takiasoko (allen); nokikula, gij hun (enkelen) geeft; nakikula (allen); wokisouru, hij hen (enkelen) medicineert; wakisouru (allen); mokimoteke, zij hen (enkelen) volgt; makimoteke (allen); ngone pokisuloko, wij hen (enkelen) zenden; ngone pakisuloko (allen); mijokisano, wij hen (enkelen) vragen; mijakisano (allen); nijokiame, gij hen (enkelen) kust; nijakiame (allen); ona jokidoana, zij hen (enkelen) schelden; ona jakidoana, (allen);

o kaso jokigoli, honden hen (enkelen) bijten;

$o$ kaso jakigoli, honden hen (allen) bijten.

Tusschen jokiirwa (er-niet-zijn van een groot aantal menschen) en jakiiwa (er-niet-zijn van een gering aantal, b.v. twee of drie menschen) is de beteekenis juist tegenovergesteld. Alleen bij de verbale adjectieven komt dit onderscheid niet voor en houdt de $3 \mathrm{e}$ ps. meerv. joki denzelfden vorm.

Het eerste lid van joki zal wel zijn het met het objectspronomen samengestelde subjectspronomen van het Gal. Tob. enz., terwijl het objectspronomen $k i$ in samenstelling met $j a$ een dubbel object van de door het subject verrichte handeling aangeeft, m.a.w. meervoud van object.

Nog een andere eigenaardigheid, dat het Tab. in onderscheiding van de andere dialekten heeft, is, dat de subjectspronomina le ps. (excl.) mv. 2e en 3e ps. mv. - reflexief den meervoudsvorm jo bij 
zich nemen, als er sprake is van veelheid van subjecten, terwijl jo achterwege blijft, wanneer slechts twee subjecten de handeling verrichten, m.a.w. meervoud van subject:

mimaosiki, wij (enkelen) baden; mijomaosiki (velen); nimaídu, gijlieden (enkelen) legt je neer; nijomaídu (velen); ona imaóko, zijlieden (enkelen) staan; ona jomaóko (velen);

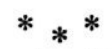

In het Nederlandsch van een familie sprekende, gebruikt men den familienaam in het meervoud, daarmee bedoelende het gezin in het algemeen: de ,van der Lindens” waren niet thuis, of : de „Broekmeijers" gaan ook naar het concert, enz. Iets dergelijks heeft het Tab. in de uitdrukking: (mannelijke eigennaam Saláka): ona na Salaka ona of : ona na Saláka, ,zij, de Salaka's, zij”, waarbij de substantief- en eigennaamsaanwijzer $o$ wegvalt;

(vrouwelijke eigennaam Pulasári) : ona na ngo Pulasári ona of : ona na ngo Pulasári, ,zij, de Poelasari's, zij”, het gezin of de familie Poelasari. Of nu na een verkorting is van het pers. vnw. 3e ps. mv. ona of van het aanw. vnw. ena, moeten we in het midden laten, hoewel de laatste meening ons waarschijnlijker voorkomt, aangezien de pleonastische vorm van spreken, welke den Tabaroes eigen is, wel niet zóó uitgebreid zal worden, dat hetzelfde persoonlijke voornaamwoord tot driemaal herhaald wordt. In het Mol. Mal. heeft men: dorang Pattimoekai, zij, de Pattimoekais, (dorang = verk. van diaorang).

Bezittelijke voornaamwoorden.

Deze zijn:

$a i$, mijn ; verkort $i$;

ani, uw, je; verkort $n i$;

awi, zijn; verkort wi;

$a m i$, haar; verkort $m i$;

$m a$, z'n, d'r (voor kinderen, familiebetrekkingen, dieren en zaken);

nanga, onze (incl.);

amia, onze (excl.); verkort mia;

ania, uw ; verkort nia;

manga, hun, haar;

Voorbeelden :

De aanvangsvocalen der bezitt. vnw. gaan in de spreektaal ver- 
loren, wanneer het voorgevoegde woord uitgaat op denzelfden klinker of op een klinker, welke zich moeilijk in de uitspraak met de aanvangsvocalen laat verbinden.

ai woa irai, m'n huis is klaar; ngoi^ $i$ woa irai, mijn huis is klaar; (in de uitspraak wordt de $i$ van ngoi met het daaropvolgende verkorte bezitt. vnw. $i$ innig saamverbonden, zoodat een gerekte i-klank ontstaat); ani zvase tamake, je hakmes heb ik gevonden; kauginika ni wase tamake, gisteren heb ik je hakmes gevonden; awi giama tasouru, ik medicineer zijn arm; ngoi wi giama tasouru, ik medicineer zijn arm; ami utu magutióka, zij knipte haar haar af; muna mi utu magutióka, haar haar knipte zij af.

De volledige vormen der bezitt. vnww. 1e ps. mv. excl. en 2e ps. mv. resp. amia en ania worden slechts zelden meer gehoord en kunnen alleen in dien vorm gebezigd worden, wanneer zij niet voorgevoegd worden door hun voornaamwoordelijke nadrukswijzers: amia soanóka jongamo, in ons dorp zijn ze aan 't kijven; tongomi mia soanoka jongamo, zij zijn aan 't kijven in ons dorp; ania bairi isoka o tatápa moikani, jelie tuin is (zoo groot als, lijkt op) als een wan van je; tongini nia bairi isoka o tatápa moikani, de tuin van jolic lijkt wel een wan van je.

De persoonlijke voornaamwoorden (voornaamwoordelijke nadrukswijzers) verrichten bij de bezittelijke voornaamwoorden dezelfde functie als bij de vervoeging, n.l. dat zij alleen dan aan de bezitt. vnww. voorafgaan, wanneer het speciaal uit den zin moet blijken, dat er van geen andere bezitting gesproken wordt dan van die, waarvan momenteel sprake is:

una wi kaso, hij, zijn hond;

ngone nanga soana, wij, ons dorp;

ona manga ngekomo, zij, hun pad (weg);

Met het voorzetsel to krijgen de persoonlijke voornaamwoorden (voornaamwoordelijke nadrukswijzers) de beteekenis van: voor, van mij; voor, van $u$; voor, van hen; enz.

Voorbeelden:

tongoi, van, voor ik (mij);

tongona, van, voor je (u, jou);

touna, van, voor hij (hem);

tomuna, van, voor zij (haar);

toma, van, voor het (z'n, d'r, 'r) (dieren en zaken);

tongone, van, voor wij (ons) incl.; 
tongomi, van, voor wij (ons) excl.;

tongini, van, voor gijlieden (ulieden);

toona, van, voor zij (hen, haar);

Het Waiolisch is de eenige taal, waarvan de o in het voorzetsel to zich identificeert met de eerstvolgende vocaal van het bezitt. vnw.: tongoi; tangana; tuunanga; tumunanga; tengene; tongomi; tingini; taananga.

\section{Voorbeelden :}

tongoi $i$ ngowaka ma tomuna iamoko, van mij, mijn kind, doch van haar is groot, d.i. haar kind is grooter dan het mijne; tongini nia demo de tongomi (mia demo) imakadaene, van ulieden, uw taal en van ons (onze taal) komen met elkaar overeen; o pipi bege tongini, bene tongomi, het geld daar is van ulieden, dit hier is van ons; enz.

Voor kinderen, dieren en zaken: $m a$ :

o ngowaka ma guguúle, het kind z'n speelgoed;

o kaso ma ngowaka, de hond z'n kind(eren), jong(en);

o boki ma bikini, de kat 'r staart;

o bole ma susu, de pisang 'r spruit;

o dodówo ne to ma titi, deze voederbak is van het varken.

Alleen in het enkelvoud voor familiebetrekkingen $m a$ :

o Dowóra ma esa, Dowora z'n moeder, Dowora's moeder;

o ngo Bobángu ma iranga, Bobangoe 'r broer; guuna ma wekata, hij daar z'n vrouw, diens vrouw;

o Aha ma bao, Aha z'n weduwe; (wordt de eigennaam van de(n) overledene niet genoemd, dan is ,weduwnaar", ,weduwe" niet bao, doch babáo: o nauru o babáo, weduwnaar; o ngeweka o babáo, weduwe).

Het Gal. heeft $m a$ ook in : o baba ma ngopa, vader z'n kind, vaders kind. In het Tab. is deze uitdrukking ongeoorloofd, aangezien ma ngowaka aanduidt: ei, kuiken, jong, ook: (euphemistisch) huig, clitoris, dus: ma dea wi ngowaka, vader z'n kind.

In het meervoud bij familiebetrekkingen vervalt $m a$ en wordt door de bezitt. vnww. vervangen:

o Suuróka manga wekata, de Saoeërs hun vrouwen;

o Waiolitjóka wimoi azvi biranga jamogiooko, er is een Waioliër, zijn zusters zijn tien. 
Ook bij de voornaamwoordelijke nadrukswijzers wordt $m a$ door het bezitt. vnw. vervangen :

tongone nanga rokata ka o woa moi, van ons, onze mannen (echtgenooten) zijn uit één gezin;

tomuna ami emama wosongenokáu, van haar, haar oom is gestorven.

De mannelijke en vrouwelijke eigennamen verliezen den zelfstandignaamwoord-aanduider o, wanneer het voorzetsel to voor de eigennamen komt:

o Saláka wi bebeléta, Salaka's sagodissel;

o bebeléta ne to Saláka, deze sagodissel is van Salaka;

o ngo Maréso mi sosuloko, Mareso's vlechtpen;

o sosuloko bege to ngo Maréso, die vlechtpen daar is van Mareso.

A anwijzendevoorna mwoorden.

Deze zijn :

ena, 't (het, dit); neéna, deze, dit; geéna, die, dat.

Komen verkort voor: ne, ge. In de meeste gevallen vervullen de aanwijzende voornaamwoorden de functie van bijwoorden van plaats en tijd, soms van het bepalend lidwoord, met dien verstande, dat neéna of de verkorte vorm ne alleen komt als bepaling bij de persoonlijke voornaamwoorden $1 \mathrm{e}$ en $2 \mathrm{e}$ ps. enk. en mv.; neéna en geéna zijn door innige verbinding met de pers. vnww. 3e ps. enk. en mv. tot voornaamwoorden geworden.

Voorbeelden:

bené, zie deze, dit; begé, zie die, dat; bestaan uit samentrekking van het tusschenwerpsel abeika, verkort: beika, zie, wel! plus neéna of geéna. Vraag: Heb je m'n mes al gevonden? - Antwoord: bené! zie dit (is 't)! of: begé! zie dat (is 't)!

In verledentijd-vorm met suffix u: benéu! zie dit reeds, al! begéu! zie dat reeds, al! Het prefix $b e$ in verbinding met de pers. vnww.: bengoi; bengona; bengini. Voorts in verbinding met den 3 en ps. enkel- en meerv.: neda, dit hier; geda, dat daar; una + neda $=$ nuúda, verkort: nuda; muna + neda $=$ numúda; una + geda $=$ guúda, verkort: guda; muna + geda $=$ gumúda. Nog met prefix be: benuúda, begumúda, enz.

ngoi ne tinisidingoto, ik, hier, zend aan ulieden; ngini ma ngomino neéna minisidémo, jelie zelf hebben 't ons, hier, aangezegd; muna 
mowosamokáu, geéna o tokata geéna imaokóde, zij was binnengegaan, toen de booze geest opstond; neéna mamoióli o namoro ge isóso daku o ngawa-ngawáka, thans, nu nogmaals de (die) vogel vloog in het luchtruim; o ligi geéna idoade, ena itemo, de muis klom-op, het zeide; ngoi o gasauku totike, momongo ena ngini nijoudjara, ik het zweet zoek, terwijl jelie maar lummelen.

Andere verbindingen:

una + ge $($ geéna $)=$ guúna $;$ muna + ge $=$ gumúna $;$ ona + ge = goóna; una + ne (neéna $)=$ nuína; muna + ne $=$ numúna; ona $+n e=n o o ́ n a$. Deze laatste vormen met ne (neéna) zijn zeldzamer dan die met ge (geéna), omdat men het laatstgenoemde aanw. vnw. het meest in de spreektaal gebruikt.

\section{Voorbeelden :}

ma koana guina wi tomara iopini, die koning, hij die, zijn hals is hard (regeert streng); o ngewéka gumúna mi aako ikudái, die vrouw, zij die, haar oogen zijn veel (zij kijkt teveel naar de mannen); o Tobelóka goóna jongose: „johahini”, so ona goóna joodomúwa ma ka joie-iete, de Tobelo, zij die, zij zeggen: ,zij hongeren”, aldus $z i j$, die zij, ze eten niet, maar lachen slechts; (een hatelijkheid op de vele h's, die de Tobelo in hun taal hebben; hahini (Tab. sazini, honger hebben) op eenigszins bespottelijke wijze uitgesproken, gelijkt op lachgeluid).

Voorts met nadrukswijzer: una guúna; muna gumúna; ona goóna.

In combinatie met bijwoorden van plaats (doka, daar; dai, zeekant; dina, landkant; $d a k u$, boven; dau, beneden) vertoonen zich de bovengenoemde voornaamwoorden van den 3en ps. enk. en meerv. in de volgende voorbeelden:

dokaúda, hij daar; dokamúda, zij daar; daiúda, hij daar aan zeekant; daimúda, zij daar aan zeekant; dinaúda; dinamúda; dakuúda; dakumúda; dauida; daumúda.

Voorts: tobedokaúda, dat is van hem daar; tobedokamúda, dat is van haar daar; tobedinamúda, enz. enz.

Nog: gu (verk. van guúna), plus bovengenoemde bijwoorden van plaats: gudáku; gudína; gudái; enz. Evenzoo: gumu (verk. van gumuna) plus deze bijwoorden: gumudáku; gumudái; enz.

Het aanw. vnw. ena, verkort tot $n a+n e(\operatorname{van} n e e ́ n a)=n a n e ́$, dit, dit $; n a+g e(\operatorname{van}$ geéna $)=n a g e ́$, dat, dat; na + neda $=$ nanéda, dit, dit hier; $n a+$ geda $=$ nagéda, dat, dat daar. 
Ten slotte: na + nuúda $=$ nanuúda of nanúda, verkort: nanú; $n a+m u d a=$ namúda, verkort: namú.

Zie over neéna en geéna verder bij de bijwoorden.

Vragende voornaamwoorden.

Deze zijn voor personen, onbepaald: nagoóna? wie? 3e ps. meerv. Bestaat uit $: e n a+g e+o n a=n a+g o+o n a=n a g o o n a ;(T e r n$. nagée? wie? Waiol. nagé + ana (3e ps. mv.) nagéana? wie? Saoesch (Talai) : akúna? Saoesch (dji'o) agúna? Bepaald 3e ps. enk. mannl. naguúna; bestaat uit: ena + geéna + una $=$ naguúna, wie hij ? (Waiol. agéana [a is het partikel vóór mannelijke eigennamen, gelijk aan Tab. o]);

3e ps. enk. vrouwl. nagumína; bestaat uit: ena + geena + muna = nagumúna, wie zij? (Waiol. wordt het partikel vóór vrouwel. eigennamen voorgevoegd: ngogéana, wie zij ?)

Voor dieren en zaken: okía, wat? Bestaat uit: o + kia (o is de aanduider van elk substantief en eigennaam; kia, wat.)

nagoóna ai naoko jatosiki? wie heeft mijn visch gestolen? naguúna wosira? wie (van jelie mannen) eerst? o mosa nc tonagumína? van wie (vrouwen) is deze sarong? o ngowaka okía itabagári? welk kind is voortdurend aan 't dreinen? o titi o kaso okía jagoli? Welke hond is door het varken gebeten?

Deze vragende vnww. doen ook dienst als onbepaalde voornaamwoorden, welke, om de meerdere onbepaaldheid uit te drukken, het suffix naga bij zich krijgen:

nagoóna-naga jotodangokau, asa jaaluka ma jadudunuzéási, wie (er is, die) (boomen) geveld heeft, behakt ze eerst van voren (aan den valkant), maar nog niet van achteren. Vraag onder mannen: naguúna asa wotagi? Antwoord: naguúna-naga: d.i. Wie (onzer) zal er gaan? Wie er maar zal (willen, zijn)! — enz.

Betrekkelijke voornaamwoorden, kent het Tab. niet. Door woord. herhaling en reduplicatie van het werkwoord, dat de handeling te kennen geeft van het onderwerp, waarvan in den hoofdzin sprake is, wordt de functie van het betrekk. vnw. vervangen.

Voorbeelden :

wongóse: ona, o basarama ma ngutuku jokirangi-rangíno goóna, ona jomasibáu ma jooluku, hij zeide: zij, de waringinwortels hen omstrengelende. zij die, zij zich laten kureeren, doch zij niet willen; m.a.w. zij, die door de waringinwortels worden omstrengeld, willen zich niet laten kureeren. 
una, kauginíka wotosi-tosiki guúna, o inonlo awi ngowaka wokidotosiki, hij, gisteren hij stelende, hij die, voedsel zijn kinderen hij voor hen steelt; m.a.w. hij, die gisteren stal, steelt voedsel voor zijn kinderen.

o ngezvéka gumína, ami singína ïza-izua gumúna de o ngia mosingowa-ngow'aka gunúna, dau o tonaúku moutiokáu, vrouw die, haar verstand niet zijnde zij die, en een slang zij baarde zij die, beneden in den grond zij is afgedaald; m.a.w. die vrouw, die haar verstand niet heeft en die een slang baarde, is in den grond afgedaald. (Zie verder bij Woordherhaling en Reduplicatie.)

Telw oorden.

Hoofdgetallen :

moi, een; modidi, twee; saánge, drie; soata, vier;

motóa, vijf ; butánga, zes; tumudiingi, zeven;

tuangere, acht; siwo, negen; mogiooko, tien;

mogiooko-de-moi, elf ;

mogiooko-dc-modidi, twaalf; enz.

monaoko, twintig;

monaoko-de-motóa, vijf-en-twintig ;

o nagisaánge, dertig;

$o$.nagisaánge-de-tumudiingi, zeven-en-dertig;

o nagisoata, veertig; tot en met negentig worden de tientallen op dezelfde wijze gevormd, n.l. het woord voor tiental plus eenheden.

o ratusumoi, honderd;

o tjaanamoi, duizend (andere dialekten tjala);

527 o ratusumotóa-de-monaoko-de-tumudiingi;

859 o ratusutuwangere-de-nagimotóa-de-sizeo;

Het achtervoegsel ou, al, reeds, hecht zich als volgt aan de telwoorden (met den klemtoon op den voorlaatsten klinker):

moióu, al één; modidióu, reeds twee; saangéu, al drie; soatóu, al vier; motoáu, al vijf; butangáu, al zes; tumudiingóu, al zeven; tuwongeróu, al acht; sizóu, al negen; mogiooko-de-moióu, al elf ; monaokóu, al twintig, enz.

Reeds werd opgemerkt, dat het Tab. geen tweeklanken kent, waaruit volgt dat $m o i$, een, bestaat uit $m o+i$; de eerste lettergreep $m o$ zit ook in modidi, twee; in mogiooko, tien en in monaoko, twintig, 
terwijl het Gal., Tob., Mod. en Pag. dit mo ook hebben in de tientallen.

modidi $=m o+d i d i$ (didi $=$ reduplicatie van $d i$, nog, weer, analoog met Tab. suffix $l i$; S.-W. $d i$ en Tern. ri) nog een, weer een $=$ twee. Dit didi heeft het Tab. in didisiráka $=$ didi + sira $+k a$ grndwrd. sira, eerst, vroeger; didisira, nog eerst, nog vroeger. Tab. tumudiingi, zeven (schier in alle dialecten gelijk), Tern. tomodii of tomdii hebben diingi en dii, welke bestanddeelen een samentrekking zullen zijn van resp. didingi en didi, want het Wai. heeft didingi, overmorgen, en azudidingi, eergisteren; modídi en tumudiingi wijzen bij het tellen dezelfde vingers aan, resp. den rechter en linker ringvinger en zouden misschien kunnen beteekenen ,de tweede twee" ( $t u$ analoog met Mal. doea) nl. to + modidi.

saánge, drie, heeft ange (ang) tot grondwoord, dat ook zit in tuwangere, acht (duidelijker nog in Gal. tupaänge en Tern. tofkánge); dit ange komt ook voor in Tern. gange, over-overmorgen; Wai. gangele, idem, en Wai. awugangele, vooreergisteren. Mooglijk dat ange verband houdt met Mal. tengah, midden, want bij het tellen wijzen saánge en tuwangere denzelfden (d.i. den middelsten) vinger aan, hoewel eerder gezegd zou kunnen worden, dat het Mal. tengah voorkomt in butánga, zes, maar bij het tellen van dit laatste telwoord wordt niet de middelste vinger, doch de pink geraakt. Nog een andere veronderstelling is deze, dat tuwangere in verband zou kunnen staan met het in het Mol. Mal. gebruikte toelang (Jav. teloe, drie), wat dezelfde beteekenis heeft als gange, gangele; in navolging van 2 en 7 (zie boven) wellicht $s a+$ ange eerste drie; $t u(d o e a)+$ ange tweede drie.

soata, vier, heeft als grondwoord ata (at) in alle dialekten (alleen Tern. heeft $a h a$ ), wellicht overeenkomende met Mal. empat; Jav. pat, vier; soata beteekent ook ,de vier”, d.z. de vier vingers bij elkaar (de duim uitgesloten), zooals wij gewoon zijn te zeggen:,,geef me de vijf": o giama ma soata, hand, palm; o giama ma soatika, in de hand, in de handpalm; posigiama-masoatíka, in-handen-geven, overleveren; o dou ma soata, voet, voetzool; analoog hiermee is het Tern. gia ma saha (Tern. raha = vier), hand, handpalm; hohu ma saha, voet, voetzool.

motóa, vijf, zou kunnen bestaan uit mo $(m o i)+t o a$; toa wellicht omzetting van oat (ata, at) vier, dus: $1+4=5$. Tern. heeft mo (moi) + toha, wrsch. analoog met aha (raha), vier; toa kan niet zijn het Tern. tola (identisch met Mal. tolak; Tab. toaka, af- 
hakken, afsnijden; aangezien S.-W. heeft motoara en Iboesch motoala (grndwrd. resp. toar en toal en niet toak).

siwo is het Mal. Pol. telwoord negen. Sobojo: tasía, wrsch. uit tari' sia, analoog met Mal. sembilan $=s a+$ ambilan, één afneming (van de tien).

Bij 30 heeft het Tab. nagi (en de andere dialekten ter Westkust, op voorgang van het Tern. njagi). De verwante talen op de Oostkust hebben andere vormen voor de tientallen, welke echter in wezen gelijk zijn.

Van meer dan één mensch objectief sprekende, wordt aan de telwoorden het prefix $j a$ gevoegd, terwijl bovendien de telwoorden vanaf 2 tot en met 4 eenige verandering ondergaan:

o njawa moi, mensch, iemand een;

o njazva jamidídi, menschen, zij tweeën;

o njawa jaruánge, menschen, zij drieën;

o njawa jaruata, menschen zij vieren;

Verder: jamotóa, jabutánga, jamogiooko, zij vijven, zij zessen, zij tienen, enz.

Het Tern. en Saoesch breiden deze verandering uit tot het getal 6 :

Tern.

mantjía amói (voor zaken: rimói), mensch een;

mantija ngamudii (zaken: romodídi of romdidi) van hen twee; mantjía ngarukánge (zaken: raánge), van hen drie;

mantjía ngarúha, (zaken: raha), van hen vier;

mantjía ngamotóha (zaken: romotóha of romtóha), van hen vijf ; mantjía ngarúra (zaken: rara), van hen zes;

7 en volgende telwoorden dezelfde als voor dieren en zaken met prefix $n g a$.

Saoesch:

1. o ngowa'a rimói (zaken: moi);

2. o ngowa'a ngamididi (zaken: romodídi);

3. o ngowa'a ngaduánge (zaken: roánge);

4. o ngowa'a ngaduata (zaken: rata);

5. o ngowa'a ngamotoara (zaken: romotóa);

6. o ngozva'a ngadurama (zaken: rarama);

Volgende telwoorden dezelfde als voor dieren en zaken met prefix nga. 
Alle aan het Tab. verwante dialekten op de Oostkust vormen de telwoorden ter aanduiding van een aantal menschen met het prefix $j a$; het S.W. en Tern. met $n g a$, beide waarschijnlijk in vorm en beteekenis verschillende voorvoegsels. Dit $n g a$ kan niet anders wezen dan het bezitt. vnw. 3e ps. meerv.; Tern. nga fala (volledige vorm: ana nga fala) hun huis; Saoesch: nga wala (volledige vorm: ana nga wala) hun huis; Wai. manga wala (volledige vorm: ananga manga wala) hun huis. $\mathrm{Nu}$ heeft het Tab. (en overige verwante dialekten) $j a$. Van Baarda zegt in zijn „Leiddraad” blz. 43: „Van een bepaalde hoeveelheid menschen kan men niet anders spreken dan in werkwoordsvorm ('t toestandswoord") —; (zie bij de verbale adjectieven in het Tab.) en de persoonsexponenten zijn dan ook in het Gal. (Tob. en Lod.) bij de telwoorden, ter aanduiding van een hoeveelheid menschen, precies dezelfde als bij de toestandswoorden in het Gal.: sapi (hongeren), goga (koortsen,) enz. (zie Leiddraad blz. 81). Ook in het Tab. hebben alle telwoorden ter aanduiding van een hoeveelheid menschen dezelfde persoonsexponenten als bij de z.g. toestandswoorden (lees: verbale adjectieven), behalve de 3e ps. meerv. van de verbale adjectieven. Men spreekt in het Tab. van o njawa jaruata, vier menschen; of : ona jaruata, zij zijn vier; maar niet van jasawini (Gal. jasapi), doch: jokisawini, zij, hun hongert (volledige vorm: ona jokisawini, zij, zij hun hongert); jasawini, wordt gezegd van dieren, dus dit $j a$ kan het niet zijn.

Voorbeelden :

ngona moi, jij een (in: tjei, ngona moi kogeéna: bah, jij bent me er zulk een!); wimoi, hem een, iemand; una wimoi, hij, hem een; guúna wimoi, die hij, hem een; o njawa wimoi, een mensch, hem een, een zekere ,hij”; o nauru wimoi, een zeker man; mimoi, haar een, iemand; muna mimoi, zij, haar een; gumúna mimoi, die zij, haar een; o njawa mimoi, een mensch, haar een, een zekere „zij”; o ngezvéka mimoi, een zekere vrouw.

Deze vormen zijn alle min of meer onbepaald, want wil men zeggen, dat er slechts één man of één vrouw is, dan wordt het telwoord versterkt met het nadruksvoorvoegsel $k a$. B.v. kazrimoi of $k a$ o nauru wimoi, maar, slechts één man; kamimoi of ka o ngeziéka mimoi, slechts één vrouw; soms met duga tot versterking: o soanóka ka o njazwa wimoi duga womagogogere, in het dorp was slechts één man verblijf-houdende; of : kazimoi duga o bonganóka woweléta, slechts één man is er in het bosch aan het sagodisselen. 
Het telwoord één voor menschen heeft dus zonder nadrukswijzers altijd iets onbepaalds, overeenkomende met ons: 'n hij, 'n zij.

De telwoorden „twee” e.v.v. daarentegen duiden volstrekt de te benoemen hoeveelheden aan:

i-na-tuangere, verkort tot natuangere, incl. ,ons achten”, met pers. vnw. als nadrukwijzer: ngone natuangere, wij, ons achten;

mi-ruánge, excl. „wij drieën”; met nadruk: ngomi miruánge, wij. ons drieën;

ni-midídi, ,,jelie tweeën”; met nadruk: ngini nimididi, gij, jelie tweeën.

Maar nu: ja-ruata, ,zij vier”; en niet: hen vieren, want dan zou het den vorm moeten krijgen van het verbale adjectief joki-ruata. Bij de pers. vnww. is opgemerkt, dat $j o$ een meervoudsteeken is van onbepaalde hoeveelheid en we vinden dit terug in : o njawa joratusu de jotjaana joodumu kajomarukúku, 'n honderd en 'n duizend menschen buigen zich allen neer;

o Papuáka mimoi o njazva joratusu de jotjaana mokitedeníka, een Papoesche, die 'n honderd en 'n duizend menschen voor zich houdt uitgestrekt;

joratusu en jotjaana is hier een zeker onbepaald getal. Daarentegen: o njaw'a jaratusóka pokitoóma pokibootóka manga aunu koii$a ́ k a$, honderden menschen worden tot den laatsten toe gedood, zonder dat er bloed is (vloeit).

Nog: o njawa jaratu-ratusu manga bulu kamoi, honderden menschen wier buikband slechts één is;

$j a$ is dus meer een bepaalde hoeveelheid, dat te kennen geeft: allen, zonder uitzondering (zie het verschil tusschen joki en jaki, blz. 342).

Dit $j a$ en $j o$ nu komt in beteekenis overeen met het Mal. ber: berlima $=$ jamotóa ; berempat $=$ jaruata, enz. resp. „,met z'n vijven”. „met z'n vieren”. Gebruikt men bij de objectieve wijze van spreken den 3en ps. mv. jo en $j a$, een enkele maal drukt men zich subjectief uit door een onbepaald aantal te benoemen en bedient zich dan van het partikel van de onbepaalde wijs en 1e ps. mv. incl. po. B.v. o ctoko o aako moi, poijaanóka paodomo pabootúzva, één sagokoek wij (we, men, onbepaald) honderd (kunnen die) niet opeten; masira ngone natjaanóka o Tobelóka pokikudóti, vroeger wij, ons duizend, beoorloogden de Tobelo. 
Hulptelwoorden en soortaanwijzers.

Het meestgebruikelijke hulptelwoord voor dingen van niet al te grooten omvang is: o ngai, stuk; o utongo o ngai tumudiingi, 7 stuks gaba (gedroogde bladsteel van den sagopalm); o namoro o ngai butánga, 6 stuks kippen; o kaso o ngai modidi, 2 stuks honden.

Huizen en boomen telt men met o utu; o woa o utu saánge, 3 stuks huizen; o igono o utu soata, vier stuks klapperboomen; o bole o utu motóa, 5 stuks pisangboomen;

o usa is „kam”; o bole o usa monaoko, 20 kammen pisang. Bij planken, latten van hout of bamboe gebruikt men: o eta, splijtsel; o iwanga o eta monaoko, 20 stuks planken; o tonga o eta butánga, 6 stuks bamboelatten.

Sagokoeken rekent men bij: o aako, oog; o etoko o aako siwo, 9 stuks sagobroodjes.

Een „brok”, ,stuk”, is: o ngogu (van ogu, afsnijden): o bira o ngogu mogiooko, 10 brokken (in bamboe gekookte) rijst. De lengte van bamboe telt men bij geledingen: o owa, geleding. Een stuk bamboe met één geleding ( o owa) heet $o$ wadéngo; o akcre o wadéngo moi, één koker (één geleding) water. Wat buiten de geledingen uitsteekt heet o soru; o akere o soru moi, anderhalve geleding water. Een stuk of vijf, zes geledingen, die op de onderste na doorgestoken zijn en dus voor watervat dienst doen : o doóu moi; o daluku o doóu modidi, twee bamboekokers arensap.

Een bamboestoel is o liunu of : o lizunu; o ounu o liumu soata, vier bamboestoelen (van een soort genaamd o ounu).

Een mondje vol is : o kudúu; o souru o kudúu jamomói boloásu naokere, de medicijn moet je bij mondjes (teugjes) drinken; een slok: o ngasiri moi (van asiri, slikken); uwa kananábo moi, iti o ngasiri moi, verzwelg dat niet in eens, neem enkel een slokje.

Eén enkel woord is: o demo o betongo moi.

Harsfakkels telt men bij o desoro; o silo o desoro monaoko, 20 stuks harsfakkels.

Bladen atap telt men bij o todili (de naam van de lat, waaromheen de sagopalmbladeren genaaid worden); 30 todili vormen één bilátu (van pilátu, inklemmen; 30 bladen worden tusschen twee bladstelen geklemd om ze bij elkaar te houden); o katu o bilátu modídi, o todili o nagibutánga, twee pakken atap zijn zestig bladen.

Strengen touw telt men bij o buta; o gumutuku o buta o nagimotóa, 50 strengen touw (gedraaid van het haarnet van den arenpalm). 
Een ristje is o ngele; o gudere o ngele saánge, drie ristjes kralen. Snoer is: o liba; één pakje: o sasáo moi (sao, inpakken).

Een pak pisang- en waaierpalmbladeren (gebruikt als onderlegger voor het eten) is: o gooromo (van kooromo, inelkaar-wikkelen); een pak sago: o kokonjówo; een reep: o siu; o igono o siu saánge, 3 reepen kokosnoot (posiu, uitsnijden); partje: o daga; o pare o daga soata, 4 partjes pinang.

Paar: o sabi; o kabingi o sabi tumudiingi, 7 paar geiten; o due o sabi moi de ma loti, een paar borden en een ongepaard; dozijn: o disini (verbasterd) : o lesa-lesa o disini, een dozijn oud-blauwe borden.

Tien visschen: o naoko o guriti moi (van uriti, aan-elkaar-rijgen); tien kokosnoten: o igono o saráu moi; tien kippen: o namoro o saráu moi.

Veertig maiskolven: o ngcle moi; een tros pisang: o gotjéla moi; een tros klappers: o sakuru moi; een tros langsatvruchten en een halm rijst: o oki moi.

Een kudde: o duwo moi of o duono moi (van tuono, achterelkaarloopen); een school (visschen) : o tika moi; een troep (menschen) : o bolu moi (van polu, verzamelen, Tern.).

Lengtematen: o busánga moi, een span; o tapisu moi, van duim tot halven wijsvinger; o mongóo moi, een vadem; o badangi-masongóna, halve vaden (lett. het halve lichaam); o taraanutu moi, 10 vadem.

Inhoudsmaten: o tjupa moi, kleine bamboekoker; o kula moi, groote bamboekoker; o kula moi o tjupa motóa, een koela is vijf tjoepa; een handvol, een greep: o djobo moi (van tjobo, grijpen); o peda o djobo saánge, drie handen sago; o rokutu moi, een hoeveelheid in beide handen opgeschept, bijelkaar-geschraapt (van rokutu, bijelkaar schrapen).

Vermenigvuldigende telwoorden vormt men met warasa, keer, maal, welk woord ook kan vervangen worden door ma, behalve „één keer, één maal”, hetwelk met ma gevormd wordt: mamoi, één keer, ééns; o salu ge nijakiloliti ma warasa tumudiingi of: o salu ge nijakiloliti ma tumudiingi, het dorpsgebouw moet jelie zevenkeer omringen.

Rangschikkende telwoorden vormt men door voorvoeging van ma: mamodídi, tweede; masaánge, derde; masoata, vierde, enz.

Dl. 84. 
De ,eerste” is niet van het telwoord ,een” afgeleid, maar van sira, vóór, èèr; de eerste: masíra-siráka; de allereerste: madidisiráka (zie bij de afleiding van telwoord ,twee”) masira, vroeger.

De ,volgende" is: ma daduku (van dadu, gelegen; dadu + uku [benedenwaarts] $=$ daduku); de ,laatste" is: ma dodogumu (van togumu, ophouden).

De „middelste”: ikoróna; middelste kind: ma goróna; het eerste kind: ma riaka; het volgende: ma dodoto; het laatste of de hekkensluiter: o susu ma bidili, die de borst loslaat (van pidili, loslaten).

Verzamelende en verdeelende tclwoorden worden gevormd door herhaling: jamomoi, bij eenen, een voor een; jatutumudiingi, bij zevenen; jaratu-ratusu, bij honderden; o njaz'a moi, o njawa moi manga singina-masíka, ieder mensch, een elk z'n eigen verkiezing, of: o njaz'a jamomoi manga roese-ma-utumu, een ieder heeft z'n gelukje.

„Allen” voor menschen: joodumu; ona joodumu jomasidaaiki, zij zijn allen opgebroken; voor zaken: iodumu; o z'ange iodumu, alle dagen; ,veel” voor menschen: jokudái of gudái, veelte; o nauru jokudái, veel mannen; o nauru manga gudái, mannen van hen veel; voor zaken: ikudái; o besaka ikudái, veel regen.

Door reduplicatie versterkt zich de beteekenis: o iuru ikukudái, uitermate veel mieren; ma gudai, veelte van: o wange neéna o besaka ma gudái, vandaag is er veelte van regen; voor „massa” zegt men dikwijls inplaats van kudái (gudái) „amoko”, groot: o besaka iamoko, een massa regen ; awi bira woutukino ianokúku, hij oogstte een massa rijst. Het richtingsaanduidend suffix $u k u$ (afwaarts, benedenwaarts) wordt gehecht aan woorden, die ,heelemaal”, ,ten eenemale”, ,tot den laatste toe" beteekenen: ngone poodu-odumúku, wij tot den laatsten toe; josongene kamamoíku, zij stierven allen in eenmaal.

Een beetje is: maéta (van eta, splijten, deelen); een heel klein beetje: maleléta (Gal. leta, Tab. eta); „meer” is: folói of paili: o bira o bajungu monaoko ifolói, meer dan 20 baaltjes rijst; o naoko o beki saúnge ipaili, meer dan 3 beki (1000 st.) visschen.

Eenige (voor menschen): jamurúo of jamuruonága; jamuruo joweléta? Hoevelen zijn er aan 't sagodisselen? jamuruonága; ja, zoo eenige menschen; in de beteekenis van: sommigen, enkelen, eenigen, munika, dat voor menschen en zaken op dezelfde wijze gebruikt wordt: o Isilamóka munúka, sommige, eenige Islammers; o paréta munúka, sommige, enkele bevelen; „louter”, „enkel” is: 
ifara-fara of ifaráku: awi namoro ge ma gosi o gurátji ifara-faráku, de eieren van z'n kip waren van louter goud; ami roeséno o pepéke ifaráku, om haar lichaam was het enkel modder.

Vragende telwoorden zijn: murúo? hoeveel; voor menschen met het voorvoegsel ja: o njaz'a jamurío? hoeveel menschen? o woa o utu murúo? hoeveel stuks huizen?

Gebroken getallen kent het Tab. niet; ,halve”, „,helft'” is : o igono moi de ma songóna, één kokosnoot en een halve ervan $=11 / 2$. Voor „halve cent" gebruikt men het uit Mal. overgenomen o seng masaténga. (Mal. setengah sēn).

Werkwoorden.

De vraag, wat werkwoorden in het Tab. zijn, kan alleen bepaald worden door het gebruik, waaruit blijken moet of deze al of niet met persoonlijke voornaamwoorden (to, no, wo, mo, mijo, nijo) verbonden kunnen worden.

toimi, kan zijn ,boog”, maar ook: met den boog schieten, pijlen; gumáa, vischhaak, maar ook: hengelen; lara, gevangenis, ook: gevangenzetten; manarama, werk, ook: werken; mokuru, betel, ook: pruimen; manái, makker, ook: vergezellen; ngowaka, kind, ook: baren; nanere, droomen, ook: droom; souru, medicijn, ook: medicineeren; koana, vorst, ook: vorst worden; mede, maan, ook: in-demaan-loopen, (,manen”, om wild te jagen); nauru, man, ook: zicheen-man-toonen; sidete, zeil, ook: zeilen; singina, hart, verstand, ook: denken; ugaka, suikerriet, ook: suikerriet-kauwen, enz.

De werkwoorden kunnen verdeeld worden in: transitieve, welke een direct object regeeren, en intransitieve werkwoorden, welke een indirect object regeeren.

Primaire intransitieven zijn:

oara, hardloopen ; gogere, zitten, wonen, verblijven ; isene, hooren ; tase, kruipen; orese, schreeuwen; tumutu, wijzen; kadunu, knikken; tagi, gaan; tuúru, achteraankomen; lio, terugkeeren; iete, lachen; oluku, weigeren;

salai, dansen; wesesongo, bevelen; ari, huilen; haga, pummelen (domme dingen doen) ; tuиmunu, duiken; soródo, gulzig-zijn ; supu, naar buiten gaan;

kuarene, bevallen (lett. zich lichter maken); asa, dragen (in: $o$ njawa moasa, zij een mensch draagt $=$ zwanger $)$. 
Tot deze soort behooren ook de woorden, waarvan vele in het Gal. onder de rubriek „,toestandswoorden” (verbale adjectieven) gerangschikt worden en die in het Nederlandsch gevormd worden met het hulpwerkwoord ,zijn”.

Voorbeelden:

siri, ,zieken”, ziek-zijn; wosiri, hij ziekt, hij is ziek; piloko, blindzijn; o pokorukósi wopiloko, vanaf den (moeder)buik was hij blind; potoono, gezond van gestel zijn; una wopotoono, hij, hij is gezond; faáro, koortsen; nofaáro? heb je koorts? kuata (uit Mal.) sterk-zijn; ona jokuata, zij, zij zijn sterk; kakuru, lang-zijn; guına wimoi wokakuru ifolói, hij daar, dat is me een lang iemand; tebini, schoon, reinzijn; pepéke, vuil-zijn; uwa nopepéke ikudái, salingóu notebini, laat af van vuil te zijn, het is behoorlijk, dat je schoon bent; tiimono, bejaard-zijn; perćki, oud-zijn ; gumúna motiimonokáu, moperekiwási, zij die, zij is al reeds op leeftijd, maar ze is nog niet oud; kudái, veel-zijn; ngone pokudái kogećna done paakunu, wanneer wij met zoovelen zijn, dan zijn we ertoe instaat; amoko, groot-zijn; tingoono, klein-zijn; ngaro ma dodoto moamookáu ma, muna kamotingoonosi, hoewel haar jongere zuster al reeds groot is, blijft zij nog slechts klein; pesaka, nat-zijn; gagini, dauwtrappen; nogagini asa nopesaka kamamói, wanneer je dauwtrapt, zal je in éénmaal nat worden; tiikiti, hoesten; totiikiti masala, ik hoest verschrikkelijk; patilanga, stijf-zijn; ngoi topatilanga, ik, ik ben stijf ; mou, stom-zijn; momou, zij is stom; morene, blij-zijn; lugu, kreupel-zijn; o njaz'a guúna wolugu-lugu so womorenuzéu, die man, hij is kreupel, dus is niet meer blij.

Voorts nog: pelelaka, mager-zijn; pululunu, dik-zijn; burére, vetzijn; kangéla, afgemat, lijden door ziekte of anderszins; tubuiso, zwaar-zijn van gewicht; kiooko, in-slaap-zijn; dudungu, droog-zijn; tjawáro, geleerd-zijn; solimóngo, dwaas, dom-zijn; enz.

tagasaanga, zich verslikken met voedsel, behoort bij de verbale adjectieven; (zie aldaar).

Tot de intransitieven behooren ook de ww. die, hoewel een object bij zich hebbende, dat object niet maken tot een direct voorwerp van de handeling. Deze ww. geven te kennen, dat de handeling, welke verricht wordt, een zekere gewoonte is van het subject, dat met de handeling bezig, doende is en dat de handeling verricht, hetzij nu, vroeger of in de toekomst, dus een duratiefvorm, die dan ook meestal den imperfect heeft. 
Voorbeelden :

o wange o duniáno wosupu-supu geéna o ngorumíka una woodomo o bole o ngai moi, o wange-maata una woodomo o bole o ngai modidi; izuangéde o ngorumíka una woodomo o bole o ngai saánge de o zvange-maatuku una woodomo o ngai soata.....; kogeénade una woodomo o wange jamomói o bole o usa jamomói, op den dag, dat hij in de wereld kwam, 's morgens hij, hij at één stuks banaan: 's avonds hij, hij at twee stuks bananen; den volgenden dag, 's morgens, hij, hij at drie stuks bananen en 's avonds hij, hij at vier stuks bananen....; aldus hij, hij at elken dag één kam bananen elken keer.

manói una wotagi o peda wotodanga la una w'omadcbcléta, op een keer hij, hij ging sagoboomen omkappen, opdat hij voor zich zou sagodisselen.

ma dea wotcmo: ino, nanga lukama podoa: zijn vader zeide: kom hier, laten we onze langsat(vruchten) klimmen.

ma koana o w'ange-masizaríc o daluku moi wotutuku de una womaosisi, de vorst van het oosten, een arenpalm hij, hij klopte en hij piste.

muna mitimáju ma ka o gabiri-ma-boro una womokuru, zij, zij gaf hem te pruimen, doch slechts jasmijnknoppen hij, hij pruimde.

tumudiingoka asa nanga wange madodogumu so ngini o naoko magudái nijotikési, nog zeven (dagen) dan is het onze laatste (feest)dag, dus jelie moeten nog eens een massa visch gaan zoeken.

okia nodiái? wat maak je? (waar ben je mee bezig);

$o$ woa todiái, ik ben aan 't huis-maken.

In het Nederlandsch worden deze werkwoorden het best weergegeven met: bananen-eten; sagoboomen-kloppen; langsat-klimmen; arenpalm-kloppen; jasmijnknoppen-pruimen; visch-zoeken, enz.

Primaire transitieven zijn :

tike, zoeken; make, vinden, verkrijgen, zien; asa, brengen, dragen; suloko, zenden, opdragen; idja, koopen; osiki, baden; sidele, ophangen; ese, halen; moteke, volgen; pelénga, opendoen; lega, kijken naar; poa, uitstorten; uиmu, oplezen; ganu, dooreenmengen; mao, voelen; akunu, kunnen, vermogen, in-staat-zijn;

towitike ma towimakéwa, ik hem zoek, doch ik hem niet vind; o peda ge naasáno de wonisuloko la o gasi waidjási, breng die sago herwaarts en draag hem op, dat hij nog zout koope; tomaosiki asa ni guba tasidelika, ik zal me eerst baden, dan zal ik je gordijn ophangen: 
ni dodoto womiese la noimoteke, neem je jongeren broer (op) en volg me; $i$ dodái tapelénga, talega ena ma doda japoakáu so taunóka ma, kede, o dowóngi josikaganuokáu so tamao taakunúza, ik doe mijn kist open, ik zie er naar, terwijl zij den inhoud hadden uitgestort, aldus las ik het (den inhoud) op, maar hoe akelig, zij hadden er zand dooreengemengd, dus ik bevond me er niet meer toe in staat te zijn (om den inhoud op te lezen).

$\mathrm{N}$ a a mwoordelijke werkwoorden.

Deze zijn substantieven en adjectieven als werkwoorden gebruikt:

o koana, vorst; geenáka ma dea wosongene, asa una wokoana, toen zijn vader stierf, hij, hij (werd) koning;

o sacke, hoofd; guúna wosacke ma, wi paréta imaái, hij is hoofd, doch zijn bestuur is slap; awi singina iamoko, iso womasaeke, zijn hart is groot (hooghartig), alsof hij zich een hoofd wil gelijk maken;

o faáro, koorts; muna mofaáro, siadono mi aako igokoko, zij koortst, zoodat haar oogen hol staan;

o mokuru, betel; tjei, kamanoimi nomokuru de noodomuwáu, foei, jij pruimt maar altijd en je eet heelemaal niet meer;

o ngowaka, kind; o kaso ingow'aka masaangéu, de hond jongt al voor de derde keer;

o roese, lichaam; o titi jahipo-hiporo ge iroese, het varken, dat gewipt (gepijld) werd, is zwanger (bezet);

o halefúru, boschmenschen, kinkels, stommelingen, ezels; uz'a nijohalefúru, la uwa nisiiete, weest niet zulke kinkels (stommelingen), opdat ze jelie niet uitlachen;

o besaka, regen; ubaá! ibesaokauóli! mijn hemel, 't begint alweer te regenen:

o nauru, man; ika, nonauru la ilaku ngona! vooruit, wees kloek, mannelijk, opdat gij overwint!

o manái, gezel, makker; ngoi tonimanái so ngarouzuáu nimodongo, ik, ik je tot gezel zal zijn, niet noodig, dat je bevreesd bent;

o ugaka, suikerriet; nougaka ikudái, asade ni ingiri iso o dofáe ma garese, wanneer je veel suikerriet kauwt, (worden) je tanden gelijk het witte van kalk. 
o manarama, arbeid, werk; ona jomanarama ma, manga manarama isupúwa, zij, zij werken doch hun werk komt niet naar buiten (er komt niets uit hun handen);

o etoko, gedroogd sagomeel; ika, o etoko nijoetoúku! vooruit, zeef jelie het sagomeel!

o gogo, huidhaar; una wogogo-gogo, hij is een harig man;

o surono, gat; o tonga pasurono, de geledingen van de bamboe opensteken;

o ngekomo, weg; o akcre podengekomo, het water "beweggen" = gootmaken ;

o singina, hart, verstand; muna ami ngozuaka mosingina so mi singína isiri, zij bemint haar kind zóó, dat haar hart er ziek van is ;

o lara, gevangenis; ma sangádji wilaráka, het distrikshoofd zette hem gevangen;

o dabo, wond; z'odabo-dabo guína kazvonatáse, hij, die met wonden behept is, kan slechts kruipen;

o tonaka, land; macta asa de itonaka, straks is het eb; enz.

Hiertoe behooren ook de instrumentalen:

o ngootiri, prauw; nolingana bolo nongootiri? ga je overland of per prauw?

o souru, medicijn; ai giana tasouru bolo tasosourúwa ma kakogeéna, of ik mijn hand medicineer of niet, 't is al eender;

o gumáa, vischhaak; una wogumáa de isioara, hij hengelde en ze deden (de haak) wegloopen (de visschen sleepten zijn haak weg);

o djaa, werpnet; totagi todjaa, ik ga, ik net-werpen;

o toimi, boog; o toimi-mangowaka ge ianokóli so potoimi paakunúwa, deze pijl is te groot, er kan niet mee geboogd worden;

o sidete, zeil; o korebánga so posidete jaózva, 't is landwind. dus er kan goed gezeild worden;

o sarimi, pagaai; o halefúru josarimi itoróu, boschmenschen pagaaien slecht;

Voorts de denominatieven, welke reeds onder de primaire intransitieven in zinnen behandeld zijn: siri, ziek; peréki, oud; kakuru, lang; pesaka, nat; enz. 


\title{
Verbale a d jectieven (toestandswoorden).
}

Reeds is opgemerkt, dat vele Gal. woorden, welke onder deze rubriek vallen, in het Tab. de actieve werkwoordsvorm vertoonen. Toch heeft ook het Tab. een aantal woorden, die te kennen geven, dat het object in een zekeren toestand verkeert, hetzij vroeger, nu of in de toekomst. In het Nederlandsch worden deze werkwoorden gevormd met de hulpwerkwoorden: hebben en zijn.

Voorbeelden:

Enkelv.

itootasa, mij toornt;

nitootasa, $\mathrm{u}$ toornt;

witootasa, hem toornt;

mitootasa, haar toornt;

jatootasa, (kind, dier).

\author{
Meerv. \\ inatootasa, ons (incl.) toornt; \\ mitootasa, ons (excl.) toornt; \\ nitootasa, ulieden toornt; \\ jokitootasa, hun toornt; \\ jatootasa, (kinderen, dieren).
}

Deze vormen zijn dus precies dezelfde als de vervoeging der w.w. met het pers. vnw. 3e ps. mv. als subject en de overige pers. vnww. als object (zie blz. 341) en uitgezonderd den 3en pers. mv. als object, hebben ook alle pers. vnww. in verbinding met de telwoorden deze vormen (zie blz. 352 en 353).

Tot deze verbale adjectieven behooren nog:

eto, dronken; wieto so wi singina isago-sago, hij is dronken, dus zijn hart is verdeeld;

tirine, beven; mi ngowaka iotaúku de muna mitirine, haar kind is naar beneden gevallen en zij beeft, rilt;

punusu, verzadigd; ipunusokáu so toodomuzwáu, ik ben verzadigd en eet dus niet meer;

pelesoko, moede; gumúna o njawa moasa, mipelesokóu, zij is zwanger, zij is al moede;

sowo-sowono, snikken; gumúna mimoi moari misowo-sowono, siadono mi ngomasa itoróu, zij daar huilt, dat ze ervan snikt, zoodat haar keel van streek is;

tuuduku, landerig, lui; inatuuduku boloásu inasazvini, wanneer we lui zijn, moeten we hongeren;

kiwoumu, zat-zijn; iets niet meer kunnen eten, omdat men het al zoo dikwijls gegeten heeft; iets vervelend gaan vinden: ai sióde kananoimi o ngafi, kaikizeunude, mijn toespijs is maar altijd ngafi (heele kleine vischjes, die men alleen eet, als men niet anders krijgen kan) ik ben 't zat; 
todokana, schrikken; wonanere wolutúku so witodokana, hij droomde, dat hij verdronk, aldus schrok hij;

sabirokata, honger, gebrek lijden, in lang niet het gewone voedsel genieten of genoten hebben; nane nanga bira kamasazini ifaráku, boloásu inasabirokata, thans, ditmaal is onze rijst louter leege doppen, 't kan niet anders of we moeten gebrek lijden;

sazwini, honger hebben; a kede, dau ania roese de ania njazua nisawini, och heden, beneden (in de onderwereld) lijdt jelie honger aan je ziel en je lichaam;

gogama, 't koud hebben, koortsig zijn (niet: koorts hebben, dat is actief : faáro, terwijl het wisselwoord voor faáro is de actieve vorm: pogogama en niet inagogama); tjci, igogama masala de ibesaokauóli, he, ik ben ontzettend koud (huiverig, rillerig) en nu begint het alweer te regenen; (verwante dialekten hebben voor koorts: gaga, gagama, kakama, goga, gogama);

tora, ontstellen, 'n stuip krijgen van schrik; dakuúku o garúdu iuti de jokitora, van boven kwam de garoeda (vogel uit de fabelenwereld) naar beneden dalen en men ontstelde; surugógo, zich verslikken; pookere pomakasano asa inasurugógo, wanneer we drinken en (tegelijkertijd) elkaar vragen (doen), verslikken we ons;

maeke, beschaamd; una manga bionóka woicte so jokinacke, hij lachte vóór hun gezicht, zoodat ze beschaand waren; tunnisi, obstipatie; o parúru naokere la uwia nituunisi, drink een purgeermiddel, opdat je niet verstopt raakt;

modongo, bang-zijn; o basarama ma datekino ngomi mimodongo, dicht bij een waringin zijn we bang.

Voor kinderen en dieren: $j a$ :

o wange moi o ngozuaka o akeróka, boloásu jagogama, een heele dag zijn de kinderen in het water, 't kan niet anders dan dat ze koortsig zijn;

o ounu magudái o daluku magoáka jactóku, een massa wespen liggen dronken aan het ondereind van den arenpalm;

o sinapani ipotóka so o djara jatodokana, het geweer knalt, het paard schrikt; enz.

Het Gal. heeft voor den 3en ps. enk. en mv. onzijdig (dus: kind, dier, zaak) : da (Lod. dja) : ai gia dasiri, mijn hand doet zeer;

ni boki dagoga, je kat heeft koorts; $d a$ is dus gelijk aan Tab. $j a$. 
Voor zakcn evenwel heeft, in afwijking van het Gal. en Lod. het Tab. geen $j a$, doch dezelfde exponent als bij de subjectieve vervoeging voor zaken, nl. $i$. De Tabaroe zegt niet: ai giama jasiri, maar: ai giama isiri. Dezelfde vorm dus, waarmee de adjectieven gevormd worden. De eenige uitzondering op dezen regel is owa, goed, dat de exponent $j a$ heeft, zoowel voor personen als zaken:

ngona jaowa, gij zijt goed; muna jaowa, zij is goed; ona jaowa, zij zijn goed, enz.

o njawa jaowa de o njawa itoróu, goede en slechte menschen; awi singina jaowa, zijn hart is goed, hij heeft een goede inborst; ne o gota jaow'a, ge itoróu, dit is goed hout, dat is slecht.

Als regel geldt dus voor zaken, dat alle intransitieve werkwoorden en verbale adjectieven zich vormen met de subjectsexponent $i$ :

$o$ kaso igoli, de hond bijt; o boso isauku, de pan is heet; $i$ wase itodomo, mijn hakmes is scherp; o gotoaka isoso, de witte kakatoe vliegt; mi mosa ipesaka, haar sarong is nat; o ngasuku ikcléko, de paal staat scheef; o Waladáka manga kai iarese, de huid der Hollanders is wit; o tonaka ne itcrcboko, deze aarde is rood; ani biono itero, haar gezicht is mooi; o naoko itumunu, de visch duikt; o teto itubúso, de steen is zwaar; enz.

„Er-niet-zijn” van menschen wordt op dezelfde wijze gevormd als de verbale adjectieven: ngoi iizwa, verkort: ngoïwa, ik, mij niet is; ngona niiz'a, gij, u niet is; una wiizwa, hij, hem niet is; muna miizwa, zij, haar niet is; ngone inaizi'a, wij, ons niet is (incl.); ngomi miizwa, wij, ons niet is (excl.); ngini niizwa, gij, ulieden niet is; ona jokiizwa, zij, hun niet is.

Voor kinderen en zaken: ai ronga modídi iizwa, mijn bijnaam niet is; onbepaald: o njaz'a moiizu, er is geen mensch; konoiiza, niemand (er is).

Zoogenaamde onpersoonlijke werkwoorden, welke in het Nederlandsch met „het” gevormd worden, nl. het regent, het waait, enz. geeft het Tab. weer of door eenvoudige vermelding van het substantief zonder meer of door vermelding van het substantief met voorvoeging van de subjectsexponent $i$, waardoor de substantieven in werkwoordsvorm geplaatst worden:

o besaka, regen; wil men zeggen ,het regent”, dan zegt men eenvoudig o besaka, 't regent; o besaka iamoko, regen groot $=$ het regent hard; kauginika o besaka isoka o wadengóka jatakuáa, gisteren 'n regen (regende 't) alsof ze bamboes schuin naar beneden 
hielden, m.a.w. het goot bakken van den hemel; dua ibesaka, straks gaat 't regenen; itoingów'a de ibcsaka, niet lang meer of 't zal gaan regenen.

$o$ tazvi-tawi, bliksem, 't bliksemt; o dadoko, wind, 't waait; o dutúru, donder, 't dondert; deze woorden kunnen niet door $i$ in werkwoordsvorm gebracht worden, vgl. onze woorden ,eb”, ,,vloed”, welke evenmin in werkwoordvorm voorkomen: het is eb, het is vloed, enz.

itonaka, 't grondt, 't ebt (de grond wordt zichtbaar); nećna o donaka, thans is er eb; o dobcle, vloed; idobcle, 't vloedt; o wangcikoróna itonaka ma o wange-maata idobele, 's middags is het eb, doch 's avonds vloed. Bij itonaka en idobele is o akere (water) eigenlijk het verzwegen subject en dat zal ook wel bij ibesaka ('t regent) het geval zijn, dus: o besaka ibesaka, regen, 't regent. Iets dergelijks hebben de uitdrukkingen : o akere iakcre, woordelijk : water, 't watert, d.w.z. water, dat drinkbaar is, drinkwater, tegenover: o akere iosa, 't water (is) zilt, enz. Voorts nog: o obiri, nacht; iobiri, 't nacht, 't donkert; iobirúku, de avond valt; o gagini, dauw; igagini, 't dauwt; o kinitara, licht; ikinitara, 't licht, 't daagt; ade ikinitaróu, 't is al bijna licht, dag.

\section{Afgeleide intransitieve en transitieve werkwoorden.}

Over het voorvoegsel si.

Wat den vorm betreft, treedt si meer op als los voorvoegsel dan als vast prefix. Het argument of men si met het grondwoord in één woord wil schrijven of niet, kan niet worden uitgemaakt door de opmerking, dat er tusschen si en het grondwoord nog andere prefixen of een reduplicatie-lettergreep kan ontstaan, want men kan $s i$ evengoed voor een secundairen als voor een primairen stam voegen. Het meest juiste zal wel zijn, si aaneen te schrijven met het grondwoord.

1. Het voorvoegsel si vormt niet in de eerste plaats causatieve werkwoorden. Een voorvoegsel dat een uitsluitend causatieve beteekenis heeft, kent het Tab. niet. De toestand is ongeveer, zooals 
in het Mal. nl. dat de causatieve beteekenis ontstaan is uit de instrumentale. In het algemeen kan gezegd worden, dat de werkwoorden met si hun object indirect regeeren, d.w.z. dat het object staat in den datief, die instrumentaal is, den concominatief of welken naamval dan ook, dien wij omschrijven met: aan, door, op, mot, tegen, enz.

Waar nu van het object wordt gezegd, dat het de handeling verricht met: door, met-behulp-van, door-middel-van het indirect object, daar wordt ook wel de nadruk van het handelend object verplaatst naar het middel of werktuig, waarmee de handeling verricht wordt, zoodat de voorstelling deze wordt: het subject laat de handeling verrichten door het indirect object. Verder nog: het subject doet het indirect object de handeling verrichten. Op deze wijze ontstaat de causatieve beteekenis uit de instrumentale, welke laatste weer een der vele functieën is van het indirect object, hetwelk door een werkwoord met si geregeerd wordt. Zoo is dus de causatieve beteekenis een jongere functie van het voorvoegsel si, welke wel verre van de meest voorkomende te zijn, bij de meerderheid der voorbeelden voorkomt.

De meest algemeene functie van $s i$ is het aanduiden van het indirect object, door ons met allerlei voorzetsels aan te duiden.

Voorbeelden van werkwoorden met indirect object (uitgezonderd instrumentaal object) :

ame, ruiken; siame, beruiken;

lefo, schrijven; silefo, beschrijven;

meta, mikken; simeta, richten op, koersen ;

dotoko, leeren; sidotoko, aanleeren;

gegoto, aandringen; sigegoto, dwingen;

fangu, betalen; sibangu, afbetalen;

oto, hakken; sioto, behakken, kerven;

oto, hakken; sigoto, slaan-in, er-in-slaan;

parisi, krabben (van kippen); sibarisi, uit-elkaar krabben;

paiti, graven; sibaiti, graven ter wille van, iets ingraven, begra-

ven (niet van menschen);

tarisi, schenken; sidarisi, er-naast, er-overheen schenken;

otaka, brengen; siotaka, brengen-mee, meebrengen;

tитипи, duiken; sidumunu, duiken met;

isene, hooren; sigisene, luisteren naar;

temo, zeggen; sidemo, zeggen aan, tot;

sano, vragen; sisano, vragen naar, bevragen; 
oara, hardloopen; sioara, wegloopen met;

soso, vliegen; sisoso, vliegen met;

tobongo, zwemmen; sidobongo, zwemmen met;

tawanono, waarschuwen, vooruit aanzeggen; sidaz'anono, waar-

schuwen voor, tegen;

tase, kruipen; sidase, besluipen;

tumutu, wijzen; sidumutu, wijzen naar, aanwijzen.

2. Een tweede beteekenis van si is de aanduiding van het instrumentaal object. Deze beteekenis grenst nauw aan de bovenopgegevene, doch zij wordt hier afzonderlijk behandeld, omdat uit haar in het bizonder de causatieve beteekenis is voortgekomen. De vormen met $s i$, welke een instrumentaal object regeeren, duiden aan, dat het indirect object het middel is, zwaardoor of ook slechts het voorwerp, waarmee de handeling verricht wordt. Gelijk bekend is, gaat de laatste beteekenis gemakkelijk in de eerste over.

Voorbeelden :

uiti, uitscheppen; siguiti, scheppen, uitscheppen met;

paiti, graven; sipaiti, graven met;

parisi, krabben; siparisi, krabben met;

pusuku, binden; sipusuku, binden met;

tebini, rein, schoon; sitebini, reinigen met;

amono, raken, treffen; siamono, raken met (b.v. een bamboe onder een straal water houden);

$a l u$, een boom aan den valkant inhakken; sialu, inhakken met; souru, medicijn; sisouru, met medicijn behandelen;

akere, water; siakerc, bewateren, onder water zetten;

woa, huis; siwoa, huizen met (b.v. onder een matje als geimproviseerd huisje);

awo, plank in de prauw; siawo, beplanken, planken inleggen;

akana, schillen (v.e. ananas b.v.) siakana, schillen met;

adju, aanlengen; siadju, aanlengen met;

pikiri, zeven; sipikiri, zeven met;

teo, uitpersen; siteo, uitpersen met ;

dabo, wond; sidabo, wonden toebrengen met;

$a r u$, rijstspaan; siaru, met de spaan roeren;

tomanga, wakker maken, wekken; sitomanga, wekken met;

tuduku, planten; situduku, planten, pooten met;

$a r u$, troosten, tot bedaren brengen; siaru, troosten met;

tarusu, donker; sitarusu, donker maken met; 
wako, gooien; siwako, gooien met;

lega, kijken; silega, kijken met;

doa, klimmen; sidoa, met iets naar boven gaan, iets naar boven aanreiken.

Daar men deze laatste beteekenis, nl. van doa, ook kan weergeven met: iets naar boven doen gaan en ook onder de andere hier opgegeven voorbeelden een min of meer causatieve beteekenis aantreft, behoeft het verder geen verklaring, hoe gemakkelijk de causatieve beteekenis uit de instrumentale voorkomt.

Nog:

resene, uitwijken, uit den weg gaan; siresene, uit den weg zetten, d.w.z. met iets uit den weg gaan; causatief opgevat: maken, dat iets uit den weg komt.

3. Voorbeelden van de causatieve beteekenis, welke, zooals men uit de bovenstaande voorbeelden kan zien, uit de instrumentale zijn voortgekomen :

tebini, rein, schoon zijn; sidebini, schoonmaken;

supu, naar buiten gaan; sisupu, naar buiten brengen;

okere, drinken; siokere, drenken;

odomo, eten; siodomo, te eten geven, voederen;

$u t i$, afdalen; siguti, aflaten;

oko, staan; sogoko, opzetten;

wosama, binnengaan; singosama, binnenbrengen;

pelelaka, mager; sibelelaka, zich mager doen worden door hard werken, ,abmageren”;

kasaiti (van saiti, kleven) aankleven; sigasaiti, beplakken, aan elkaar doen kleven;

tarisi, schenken; sitarisi, doen schenken; sidarisi, overschenken; peetoro, nauw; sibeetoro, nauw maken om door een smalle opening heen te wringen;

poa, storten; gopoa, overstorten; sigopoa, doen overstorten;

kububulu, inloopen (van water); sigububulu, erin doen loopen; parene, opstijgen, aan boord gaan; sibarene, op-, inladen, aan boord doen gaan;

tabi, tegenaan; sitabi, er vlak tegenaanbrengen, doen aansluiten; sidabi, omringen;

sebanga, vlak, dicht bij; sisebanga, dicht-bij doen komen;

tiái, recht, in orde; sitiái, recht, vlak maken; sidiái, in orde doen brengen, voorzichtig aandoen; 
tonga, van elkaar wijken; sidonga, uit elkaar doen wijken, de reet grooter maken;

tangono, er schuin tegenaan zetten; sitangono, er schuin tegenaan doen zetten; sidangono, overhalen;

tjobo, grijpen; sidjobo, doen aanpakken, doen aangrijpen.

Uit deze voorbeelden blijkt, dat de tenues $k, t, p, f, t j$, respect. veranderen in de mediae $g, d, b, d j$; en $h$ en $w$ in $n g$.

4. Een andere beteekenis van si wordt aangetroffen, waar dit voorvoegsel optreedt tegelijkertijd met het voorvoegsel $d a, d e, d i, d o, d u$, welks klinker zich richt naar de eerstdaaropvolgenden klinker van het werkwoord. De vormen met $d a$ (en varianten) zijn dikwijls zoo goed als synoniem met de vormen, die enkel si voorgevoegd hebben, doch waar si tegelijkertijd voorvoegsel is met het dan steeds daaropvolgende $d a$ (en varianten), dan heeft si een meervoudige beteekenis. De vraag kan rijzen of hier het voorvoegsel si hetzelfcle is als het boven besprokene, daar de beteekenis zoozeer schijnt af te wijken. Men herinnere zich echter, dat het - in de Indonesische talen zoo veel gebruikte achtervoegsel $i$ (si, $k i$, enz.) -- in zich vereenigt de beide volgende beteekenissen:

1e. de handeling verrichten aan, voor het indirect voorwerp; 2e, de handeling verrichten aan dat voorwerp op verschillende plaatsen ervan (b.v. iets aan alle kanten bekloppen) of aan vele voorwerpen slechts op één plaats. Vandaar dat zulk een vorm met het achtervoegsel $i$ in vele Indonesische talen ook dikwijls als eenvoudige meervoudsvorm optreedt. Hetzelfde schijnt hier het geval te zijn met het voorvoegsel si en zonder dat hiermede gewezen wordt op mooglijke identiteit dier beide grammatikale elementen, kan men toch aannemen, dat hier ongeveer dezelfde beteekenissen in si aanwezig zijn.

Waar si zonder $d a$ (varianten) optreedt, duidt het indirect object aan, dat het dikwijls een zekere meervoudigheid van handeling insluit, hetzij dat 'n subject en één object de handeling herhaaldelijk of aan alle kanten verricht (meervoud van handeling) of dat het de handeling aan vele objecten verricht (meervoud van object). Wanneer nu si en $d a$ (en varianten) beide tegelijkertijd worden voorgevoegd, dan heeft $d a$ (varianten) uitsluitend de beteekenis van het verrichten der handeling aan, voor, met, ten opzichte van het indirect object, terwijl si dan uitsluitend de beteekenis van meervoud der handeling aanduidt.

$s i$ en $d a$ (varianten) zijn dus twee voorvoegsels van nauwverwante 
beteekenis, welke, tegelijkertijd optredende, steeds op bovenaangeduide wijze hun functiën verdeeld houden.

Voorbeelden :

oara, hard-, wegloopen; sioara, wegloopen met; dooara, bestormen; sidooura, ervan-(loorgaan met veel dingen;

soso, viliegen; sisoso, vliegen met; dososo, afvliegen op; sidososo, met veel dingen wegvliegen;

amono, raken, treffen; siamono, raken met; daamono, raken op; sidaamono, veel malen beraken;

gamono, een wild raken, treffen; dagamono, met een lans raken op, beraken; sidagamono, met velen iets beraken;

az'ene, uitdoen, uittrekken; siazene, aandoen, aantrekken ; daazvene, uittrekken over; sidaawene, zich geheel omkleeden, omhangen, inwikkelen;

asini, wegdrijven; siasini, doen wegdrijven (van een vlot) of wegdrijven (met den stroom); daasini, aandrijven; sidaasini, afdrijven met veel tegelijk (bv. een vlot met hout);

adju, lengen; siadju, aanlengen met; daadju, erin aanlengen; sidaadju, verschillende dingen ermee inmengen;

pairi, tuinmaken; sipairi, tuinmaken met; dapairi, tuinmaken voor; sidapairi, met velen tuinmaken;

bairi, tuin; dabairi, tuinende zijn in, op (bosch), tegen (berghelling); sidabairi, met velen aan het tuinen zijn;

pesaka, nat; sipesaka, natmaken met; depesaka, plaatselijk natworden; sidepesaka, met barang en al begoten worden;

besaka, regen; sibesaka, regenen met, doen regenen (door kinderen spelenderwijs met een geharpuist blik b.v.); debesaka, beregenen; sidebesaka, door en door nat, aan alle kanten beregend worden;

asoko, roepen; siasoko, aanroepen (van geesten); gasoko, roepen om, bij-roepen; sigasoko, be-roepen, beschreeuwen (van uit de verte); dagasoko, bijeenroepen; sidagasoko, veel malen bijeenroepen of velen doen bijeenroepen;

gaasoko, vragen; sigaasoko, vragen om; dagaasoko, be-vragen, afbedelen; sidagaasoko, alles afvragen, afbedelen;

$a l u$, boom-inhakken aan den valkant; sialu, een ,alu” maken met; daalu, behakken, be-alu-en; sidaalu, eenige boomen tegelijk inhakken, zoodat ze tegelijk vallen;

aiki, uit-, afnemen; daaiki, plaatselijk uit-, afnemen; sidaaiki, met have en goed wegtrekken, verhuizen met ,al z'n hebben en houen”; 
adono, bereiken, aankomen; daadono, bepaalde plaats bereiken; siadono, een hoogte, graad (van rijpheid) bereiken; sidaadono, gelijk aankomen van velen;

booto, klaar, af, gereed; sidobooto, allen vertrokken, afgereisd;

asa, brengen; siasa, wegbrengen, geleiden; daasa, wegbrengen met, op; sidaasa, tegelijk meenemen van veel dingen;

umo, weggooien; siumo, doen wegwerpen; duumo, ergens op, tegenaan wegwerpen; siduumo, alles tegelijk wegwerpen;

amoko, groot; siamoko (meest gehoord in Tern. vorm silamo) zich verheffen, aanstellen; daamoko, grootworden in, opwassen te; sidaamoko, met iets of iemand tegelijk opgroeien, opwassen, grootworden;

ikiri, af-, uitvegen ; siikiri, uit-, afvegen met; diikiri, bevegen, beduimelen; sidiikiri, alles tegelijk uitvegen;

ese, halen, nemen; siese, doen halen; deese, halen op, in ; sideese, halen, nemen van veel dingen tegelijk;

gese, nemen, halen voor; sigese, doen halen voor; degese, op crediet nemen, poffen; sidegese, veel dingen koopen op den pof;

ali, ruilen, ook: verdwalen; siali, doen veranderen, verdwalen; sigali, vertalen, overbrengen; tagali, vergoeden, in de plaats ervan geven; dagali, overschenken (van het eene vat in het andere); datagali, uitleenen over en weer; sidatagali, velen met elkaar uit-, beleenen;

boa, komen; siboa, doen komen; doboa, tegenkomen; sidoboa, gelijk aankomen, elkaar aantreffen;

osiki, baden; siosiki, doen baden; gosiki, bad; dogosiki, baden op, aan een bepaalde plek; sidogosiki, velen doen baden op een bepaalde plaats ;

paasana, slaan ; sipaasana, slaan met; dabaasana, slaan op, beslaan; sidabaasana, slaan van veel dingen tegelijk of aan alle kanten slaan; tobaka, trekken; sitobaka, trekken met; dotobaka, erbij, erin trekken; sidotobaka, alles tegelijk optrekken (b.v. een net met visch);

surono, een gat maken; sisurono, een opening maken met; dusurono, een opening maken in, op, aan; sidusurono, b.v. alle geledingen van een banboe tegelijk opensteken;

fero, groeien; defero, begroeien; sidefero, samen laten opgroeien; noa, leggen, neerleggen; sinoa, neerleggen met (b.v. vuur met een vuurtang); donoa, erbij, erin leggen; sidonoa, veel dingen erbij, erin neerleggen ;

D1. 84 . 
omasa, ademen ; siomasa, ademen met; doomasa, beademen; sidoomasa, aan alle kanten beademen;

$o o$, leven; dooo, leven in, aan, op, tegen; sidooo, veel dingen (bv. klappers) tegelijk laten ontkiemen;

sowoko, vruchtdragen; sidosowoko, tegelijk vruchtdragen, (b.v. van een doerianboom en een manggoestanboom, welke gelijkertijd vruchtdragen);

tanuru, teeken van eigendomsrecht plaatsen bij vruchtboomen enz. sidatanuru, kleine kinderen voor elkaar bestemmen, een verloving bij voorbaat, kinderverloving.

Het voorvoegsel $d a$ (en varianten) is ook aan reduplicatie onderhevig, wanneer er sprake is van veelheid van handeling en in die gevallen, waarin wij den zin vormen met een betrekkelijk voornaamwoord.

Voorbeelden :

ame, ruiken, kussen; daame, beruiken, bekussen; dadaame, herhaaldelijk bekussen: mi ngowaka modadaame, zij bekust haar kind herhaaldelijk; o ngowaka modadaame geéna, isongenokáu, het kind, dat zij bekuste, is gestorven;

lega, zien; delega, bezien, bekijken; dedelega, herhaaldelijk bezien: awi raki wodedelega, hij beziet herhaaldelijk zijn boomgaard; o raki wodedelega geéna, jaukuokáu, de boomgaard, die hij bezag, is atgebrand;

asini, wegdrijven; daasini, aanspoelen; dadaasini, herhaaldelijk aanspoelen, aandrijven: $o$ dababoro idadaasini, zee-vuilnis drijft herhaaldelijk aan (land); o dababoro idadaasini geéna, ilutuokáu, dat zeevuil (drijfrommel), dat kwam aandrijven, is gezonken;

oara, hardloopen; dooara, be-loopen, bestormen; dodooara, herhaaldelijk bestormen: o ngorana ma bebeno jododooara, zij bestormen herhaaldelijk de deur; o ngorana ma bebeno jododooara geéna, irubáku, de deur, die zij bestormden, is omgevallen;

uisi, vloeien, lekken; guisi, aflekken, afdruipen; duguisi, afdruipen uit, van; duduguisi, herhaaldelijk afdruipen: awi dangiri ge o aunu joduduguisúku, van zijn slaapbank droop voortdurend bloed naar beneden; o aunu o dangiri joduduguisi geéna, ilepáno, het bloed, dat van de bank droop, vormt plassen.

De voorbeelden: diidu (idu, slapen, zich neerleggen; diidu, slapen op, beslapen, d.w.z. van vogels, die een vaste plek hebben, waar zij 
slapen) en duruba ( $r u b a$, vallen, duruba, vallen op) geven een innige samengroeiïng te kennen van werkwoorden met het voorvoegsel tot een substantief : o namoro ma diidu, de slaapplek der vogels; o gota ma duruba, de valplek van den boom.

Afgeleide transitieven van intransitieven en van transitieven.

Zooals uit de hieronder gegeven voorbeelden blijkt, heeft de overgang van tenues in mediae geregeld plaats, terwijl de woorden, welke met een klinker aanvangen door $g$ worden voorgevoegd en in enkele gevallen door de velare nasaal $n g$.

De vorm gïunu uit iunu is een eigenaardige afwijking.

toteke, aankloppen met de knokkels; doteke, bekloppen;

piakoro, uit elkaar halen; biakoro, klein maken;

taulu, vuurmaken; daulu, op het vuur zetten, bevuren; parisi, terzijde krabben, schuiven; barisi, afwenden, beschermen (tegen ongeluk);

totiri, op den arm dragen; dotiri, op den arm zetten;

tedama, kauwen; dedama, met kauwsel voeren, gekauwd eten voeren;

tosiki, stelen; dosiki, bestelen;

taári, staan vóór; daári, zich wenden, keeren vóór;

toku, over een boom, plank, bamboe loopen; doku, iets, iemand

benaderen, terwijl men ergens op, over loopt;

tooraka, verplaatsen; dooraka, verplaatsen naar, in, op;

torusu, afloopen van water, terugloopen; dorusu, wijken, achteruitgaan;

toboko, aangezet, aangebrand; doboko, omroeren tot op den bodem;

ari, weenen; gari, beweenen;

parene, opstijgen; barene, zitten-op, bestijgen ;

isene, hooren; giisene, vernemen;

$u t i$, dalen; guti, afdalen voor, ten behoeve van;

tumunu, duiken; duтипи, opduiken;

ese, halen; gese, halen voor, ten behoeve van;

$u t u k u$, plukken; gutuku, plukken voor; 
pelénga, openen; belénga, opendoen voor;

toóma, slachten; doóma, slachten voor;

asa, brengen; gasa, meebrengen;

tutuku, stampen; dutuku, stampen voor;

uиmu, oplezen; nguи

tike, zoeken; dike, zoeken voor;

tangi, neerstrijken, zich zetten v.e. vogel; dangi, ergens op neerstrijken;

aiki, eruit halen; gaiki, verlossen, helpen;

tulúru, opschuiven; dulíru, bijelkaar schuiven;

iunu, verbergen; giiunu, verbergen voor; enz.

Als samengestelde werkwoorden komen voor:

aako-tawi, uit: aako, oog, en: tawi, oogknippen: pomaäakotazi, zich de oogen knippen, knipoogjes geven;

giama-ma-soata, uit: giama, hand, arm; soata, vier; ma soata, handpalm, ,de vier": posigiama-ma-soata, in handen overgeven, overleveren;

galu-siri, uit: galu, voorvlakte van den romp (van alu, voorzijde maken) ; siri, zeer, ziek: pogalusiri, medelijden, hartzeer hebben;

diki-oko, uit: diki (van tiki, stuiten, niet verder kunnen), stutten, steunen op; oko, kin: pomadikioko, zich de hand stutten, zitten met de kin op de handen;

gia-songóna, uit: gia (Tal). giama) arm; songóna, half, helft: pogiasongóna, meten met een halven vadem (nl. met de linkerhand op het borstbeen en de rechterarm uitgestrekt) ;

gari-betongo, uit: gari, beweenen (van ari, weenen) betongo, woord (van feto, kletsen, prevelen) : pogaribetongo, woorden-weenen beweenen met woorden;

tila-borono, uit: tila, opschuiven, bijelkaar brengen;

borono (van porono, inwikkelen in een sarong om zich warm te maken; ook: broeden; vgl. Tern. foro, broeden; boro, ei) : pomatilaborono, vanwege de kou in elkaar gehurkt zitten en zich in een sarong wikkelen;

tanu-bane, uit: tanu, waken, afwachten; Tern. pane, bestijgen, embarkeeren: potanubane, van scheepsgelegenheid gebruik maken; rai-songóna, uit: rai, deelen; songóna, helft: poraisongóna, halveeren, in de helft verdeelen. 
Over de beteekenis der voorvoegsels.

De voorvoegsels $m a$ en $k a$.

Op blz. 338 v.v. is onder de ,Vervoeging met objecten” gebleken, dat $m a$ in het Nederlandsch weergegeven wordt met het wederkeerend voornaamwoord ,zich”. Voorbeelden:

1. tomarukúku, (rukúku), ik buig mij; womaosiki, (osiki), hij baadt zich; jomamaráu, (maráu), zij wasschen zich het gezicht; pomaluunu, (luunu), zich bedekken; pomaluiti, (luiti), zich snijden; tomakadunu, (kadunu), ik knik mij (ik knik met mijn hoofd); momapeleoko, (peleoko), zij rekt zich; pomaopini, (opini), zich stijf houden (overdrachtelijk: een harde kop hebben); womaoara, (oara), hij maakt zich uit de voeten.

Dezelfde beteekenis heeft $m a$ in de w.w. die op blz. 362 als verbale adjectieven of toestandswoorden zijn aangeduid. Worden deze verbale adjectieven niet gebruikt in de daarbij opgegeven vormen, nl. met een pers. vnw. tot object, dan wordt het objectspronomen ma:

mipelesoko, haar is moede; momapelesoko, zij maakt zich moede (met een of ander werk) ; witodokana, hem schrikt; womatodokana, hij doet zich schrikken, d.w.z. bij een zaak, die hem al bekend was, doet hij alsof hij deze nog nooit gehoord had, waarbij hij ,zich doet schrikken"; iporosono, mij huivert; tomaporosono, ik doe mij huiveren, d.w.z. de beweging van rillen, huiveren maken; inatuuduku, lusteloos, landerig, lui zijn; pomatuuduku, het zich gemakkelijk maken, een lui leventje leiden; wisarvini, hem hongert; womasazini, hij maakt zich hongerig $=$ met een leege maag rondloopen; enz.

2. Een $2 \mathrm{e}$ beteekenis van de vervoeging met ma blijke uit de volgende voorbeelden:

pomaomasa, (omasa), adem-scheppende, •verpoozende, uitblazende zijn; momakuarcne, (kuarene), zij is barende; womapereoto, (pereoto), hij is gierig, karig; momaidu, (idu), zij is rustende, liggende; momaidu-idu, zij is somnambuleerende; tomatase, (tase), ik ben kruipende; pomaoko, (oko), staande, we zijn staande; jomalega, (lega), ze zijn kijkende; womagogere, (gogere), hij is zittende; momazuaéka, zij is naakt.

Verder nog: o ngowaka womatjihóri, asa womatase, asa womaoko, asade womasinonu, asade wotagi wosaaka wotai-taili, een kind, hij is (eerst) schuivende-met-z'n-achterste, dan is hij kruipende, dan is hij staande, dan is hij volgende, dan gaat hij en stapt al probeerende; enz. 
Deze intransitieve w.w. duiden een toestand aan, waarin het subject verkeert, want worden deze w.w. gebruikt zonder het prefix $m a$, dan ontstaat een actieve handeling:

poomasa, ademen; totase, ik maak nachtelijke bezoeken; pooko, nog in leven zijn, nog ,staan” = bestaan; jolega, zij kijken; wogogere, hij zit; tokuarene, ik (ben) licht.

Er zijn enkele woorden, welke niet zonder ma voorkomen:

pomangeana, gapen; momarofu, zij blert, balkt, huilt; womatiingi, hij daagt uit.

3. Een 3e beteekenis van ma, hoewel natw verwant aan de voorgaande, doet de handeling van het subject kennen als een eigenschap, laat de werking zien als een vak, dat beoefend wordt:

Vergelijking :

jozиикипи, zij verkoopen; jomazukиnи, zij zijn verkoopende, zij oefenen de handeling ,verkoopen” uit als vak, dus: zij zijn verkoopers, kooplieden;

joteda, zij stallen uit; jomateda, zij zijn uitstallende, zij zijn uitstallers, zij zijn winkeliers;

Bovenstaande beteekenis wordt nog verduidelijkt door reduplicatie van de w.w. stammen:

ona o bira jomazuku-zukunu, zij houden zich bezig met het verkoopen van rijst $=$ zij zijn rijstverkoopers;

o Tjinaka o njazva imateda-tedaka, de Chineezen zijn menschen, die zich bezig houden met uitstallen $=$ zijn zijn uitstallers, winkeliers ;

o sikola ma njawa imadoto-dotoko, de scholieren houden zich bezig met leeren $=$ zij zijn leerlingen;

Wanneer bovenstaande vormen met $m a$ vergeleken worden met de afleidingen in het Mal., welke met ber-gevormd worden, dan blijkt, dat deze ma-vormen, hoewel vormelijk verschillende, in beteekenis gelijk zijn aan één der beteekenissen van de afgeleide w.w. stammen met ber- (ber- heeft 6 beteekenissen, zie Spkt. prof. v. Oph. § 188)

pomakulu $=$ bertjockoer, zich scheren;

tomakulu $=$ akoe bertjoekoer, ik scheer mij;

pomazusi $=$ bersisir, zich kammen;

tomawusi $=$ akoe bersisir, ik kam mij;

pomaao $=$ berpegang, zich vasthouden;

tomaao $=$ akoe berpegang, $\mathrm{ik}$ houd $\mathrm{mij}$ vast; 
pomadotoko $=$ beladjar $($ voor beradjar $)$, zich leeren;

tomadotoko $=$ akoe beladjar, ik leer mij;

pomapaasana $=$ berpoekoel, zich slaan;

tomapaasana $=$ akoe berpoekoel, ik sla mij;

o Sale o gasi wow'ukunu $=$ Sale mendjoeal garam, Sale ver koopt zout (Sale is bezig met de handeling ,,verkoopen”, niet als vak);

doch : o Sale o gasi womaz'ukunu $=$ Sale berdjoeal garam, Sale is zoutverkooper, zouthandelaar; enz.

4. Voorbeelden en beteekenis van afgeleide w.w. met $m a$ en $s i$ :

pomasipeleke (grndwrd: pelekc), zich stooten;

pomasidiai (tiai), zich gereed maken tot de afreis;

pomasidailako (tailako), idem;

pomasiobiri (obiri), zich laten be-avonden, zich donker laten worden;

pomasibesaka (besaka), zich in den regen begeven, zich nat

laten regenen;

pomasigisara (gisara), zich overgieten met;

pomasizvekata (wekata), als vrouw tot zich nemen = in cuncu-

binaat leven;

pomasizoa (woa), zich tot huis maken;

pomasinoa (noa), voor zich neerzetten, neerleggen;

pomasisori (sori), zich er dichtbij begeven;

pomasitorusu (torusu), zich achteruit begeven;

pomasibelelaka (pclelaka), zich ,abmageren” door hard werken; pomasiasini (asini), zich laten afdrijven;

pomasidaulu (taulu), voor zich te vuur zetten;

pomasilamo (lamo), zich aanstellen, verheffen;

pomasitorou (torou), zich slecht maken;

5. Voorbeelden van afgeleide w.w., welke de beteekenis hebben

$\mathrm{n}$ : voor, ten behoeve van:

pomagese (ese), voor zich halen;

pomangakunu (akunu), zich ertoe-instaat gevoelen;

pomagosumu (osumu), voor zich roosteren;

pomadiidja (idja), voor zich koopen;

pomadubukunu (wukunu), voor zich verkoopen;

pomagasa (asa), voor zich meebrengen;

pomadoóma (toóma), voor zich slachten; 
pomaguti (uti), voor zich aflaten:

pomangum (ummu), voor zich oplezen;

pomagutuku (utuku), voor zich afplukken;

pomabelénga (pelénga), voor zich ontsluiten, openen;

pomadutuku (tutuku), voor zich stampen;

pomagaiki (aiki), voor zich eruit nemen;

pomagïumu (iumu), voor zich verstoppen;

pomadugumaa (gumaa), voor zich hengelen; enz.

6. Naamwoordelijke w.w. met ma geven te kennen: zich maken tot. Geredupliceerd: zich voordoen als, zich gelijk maken met:

pomasacke, zich hoofd maken;

pomasae-sackc, zich voordoen als hoofd, doen alsof men zich

hoofd waande;

pomakoana, zich vorst maken;

pomakoa-koana, zich de allures van vorst toeëigenen;

pomanauru, zich man maken, dapper, mannelijk zijn;

pomanau-nauru, zich geheel en al als man betoonen, onvervaard zijn.

7. Een andere beteekenis van ma is de reciproque. Er bestaan evenwel twee reciproque vormen, $\mathrm{nl}$. de eene alleen met ma aan het w.w. voorgevoegd, de anclere met $m a+k a$ als gecombineerde voorvoegsels.

De le vorm vertoont zich in de volgende woorden:

pomadodóko (toko), elkaar op de hielen trappen, d.w.z. heel dicht achter elkander loopen;

pomatuono (tuono), met elkaar een stoet vormen, achter elkaar loopen ;

pomaäakotawi (aako, oog; tawi, oogknippen), elkaar oogjes, teekenen van verstandhouding geven;

pomagiatjobo (Tern, gia, hand: tjobo, vastgrijpen), elkaar de hand geven bij een weddenschap;

pomasidoku (toku), onder elkaar verdeelen;

pomasigaro (garo, Tern. karo, roepen), met elkaar overleggen, bespreken ;

pomatoomu (toomu) en pomalomu (Tern. lomu) met elkaar vergaderen, bijeenkomen.

De aard der bovenstaande w.w., waarin opzichzelf reeds de beteekenis ,wederzijdsch” ligt opgesloten, maakt een nadere aandui- 
ding van de reciproque beteekenis overbodig. Anders is dat bij de hieronder volgende voorbeelden, waarin $k a$ de werkwoorden reciproque moet maken en dus voorafgegaan door ma, aan de handeling de beteekenis geeft van: met elkaar, samen, over en weer.

2e vorm, waarbij ter versterking somwijlen het prefix $k a$ wordt geredupliceerd en $m a$ van $k a$ gescheiden wordt door $s i$ :

pomakagari, met elkaar beweenen;

pomakakagari, steeds met elkaar beweenende;

pomakanako, elkaar over en weer kennen in een zaak, met

elkaar van een of andere zaak afweten;

pomakakanako, over en weer elkaar kennende zijn, elkaar bekenden zijn;

pomakatigi, dicht bij elkaar zijn (eigenlijk: elkaar aanraken): pomakakatigi, steeds dicht bij elkaar zijnde;

pomakapoma, elkaar het zwijgen opleggen;

pomakakō, elkaar omhelzen;

pomakagisara, elkaar over en weer met water gooien;

pomakaoara, met elkaar hard wegloopen;

pomakakadooara, steeds met elkaar bestormencle;

pomakamorene, met elkaar verheugd zijn;

pomasikamorene, met elkaar verheugd zijn over;

pomakaalcle, met elkaar hoera-roepen;

pomasikaalele, met elkaar hoera-roepen over;

poinakaloláha, met elkaar vrede sluiten:

pomasikaloláha, met elkaar vrede sluiten over.

Voorts bij dieren en zaken:

o kaso imakamusungu, de honden zijn aan 't paren; (van Mal. mocsim, jaargetijde, moesson).

o nannoro imakapaárc, de hoenders treden elkaar;

o ngootiri imakataga, de prauwen stooten tegen elkaar; manga aako imakadutukuríno, hun oogen staan scheef (scheel) tegenover elkaar.

Beide vormen van $m a$, zonder of met $k a$ verbonden, zijn in beteekenis gelijk aan de Mal. vormen met bor-:

pomakakoo $=$ berpeloek, elkaar omhelzen;

of aan de Mal. vormen met ber.... an:

pomakaasoko $=$ berpangil-panggilan, elkaar roepende;

pomakapaasana $=$ berpoekoelan, elkaar slaande; enz. 
Dat $k a$ als prefix bij w.w. de aanduider is van het reciproque, blijke nog uit de volgende voorbeelden, waarin de beteekenis ligt van: twee of meer dingen bijelkaar voegen:

posikadowanga, de einden aan elkaar lasschen, binden; posikarukiti, twee of meer touwen in elkaar draaien; posikapalusu, met gekruiste beenen staan; het eene been over

het andere leggen; twee dingen als een kruis verbinden; posikaadju, eenige dingen door elkaar beslaan, aanmengen; posikaudjara, idem; posikaganu, eenige dingen dooreenmengen;

o tonga o ngai modídi isikatuúrono, twee bamboes in elkaar steken;

o giama isikasakara, de vingers in elkaar steken; de handen in elkaar vouwen;

o giama isikangosama, de handen onder den oksel steken;

o teto nijosikakaretenúku, jelie moet de steenen steeds op elkaar stapelen;

o raki pokikaogu, een boomgaard onder elkaar verdeelen;

Een enkele maal heeft het Tab. in overgenomen uitdrukkingen het reciproque $t e k c$, dat alleen voor zaken gebruikt wordt:

tekeomanga, gelijkelijk aanvullen;

tekesebulu, gelijk (tezamen) dichtmaken;

teketuru, gelijk staan, dezelfde houding hebben; verdere voorbeelden ontbreken.

2e beteekenis van $k a$.

In geheel andere beteekenis komt $k a$ (en dan geredupliceerd) voor als prefix bij w.w., die door $k a$ de beteekenis krijgen van: iets bij voortduring, bij herhaling doen; niets doen dan:

pokakabitjara, voortdurend niets doen dan praten, kletsen;

pokakasali, steeds met wisseltermen spreken;

pokakasonga, bij herhaling door een rivierbedding loopen;

pokakalingana, steeds overland gaan;

pokakatowóngi, steeds langs het strand loopen, de reis langs het strand maken;

pokakaoru, voortdurend de reis roeiende, dus per prauw makende;

pokakadagi, steeds op de been zijnde, loopende zijn;

pokakaodomo, niets doen dan eten, alles eten, wat voor de hand ligt ; 
pokakatigi, steeds dicht bij elkaar;

pokakaakuíwa, voortdurend in onmin leven;

pokakaidja, niets doen dan koopen, koopziek zijn; enz.

(zie over het geredupliceerde $k a$ bij de adjectieven).

Een 3e beteekenis van $k a$ kan weergegeven worden met: slechts, maar, stellig. Dit voorvoegsel staat vóór de w.w. stammen, doch wordt aan de naamwoorden voorgevoegd:

ona kajodoana, zij schelden maar, zij zijn slechts aan 't schelden; kaona jodoana, zij zijn het, die schelden;

una kawooluku, hij weigert slechts;

kauna wooluku, hij is het, die weigert;

ngini kanijobabaili, jelie zijn slechts wederstrevende;

kangini nijobabaili, jelie zijn 't, die wederstreven enz.

Het voorvoegsel $k a$ in verbinding met het voorvoegsel $s a$.

Van dit laatste voorvoegsel, afzonderlijk voorkomende, zijn slechts enkele voorbeelden bekend. Dit voorvoegsel geeft aan de w.w. de beteekenis van: heen en weer, links en rechts, aan alle kanten, overal:

o bongana ma boumu wasaame, (ame, ruiken, kussen), hij besnoof de boschlucht;

o ubutu wasarari, (rari, korthakken van onkruid), het onkruid hakte hij links en rechts weg;

saiwange, (wange, dag; izeange, morgen), wosaiwangcku, hij overnacht, blijft den nacht over;

saiobiri, (obiri, nacht; iobiri, 't nacht, 't is donker);

wosaiobiri, hij overdaagt, blijft den dag over;

saisongóu, (songóu, grndwrd. ngou, verschillend, anders);

isongóu, het is anders, (niet eender), imasaisongóu, het is zich geheel niet gelijk, overal verschillend;

saisizuara (siz'ara, schijnsel; isizwara, 't schijnt), isaisiz'ara, 't schijnt overal heen, naar alle kanten.

Hiervan het zelfst.nw. o daluku ma saisizuara, de pennen (welke naar alle richtingen uitsteken) van het haarnet van den arenpalm.

Gecombineerd met sa komt het voorvoegsel $k a$ voor bij w.w., waardoor de beteekenis ontstaat van: de een na den ander dezelfde handeling verrichten, aan eenzelfde werk bezig zijn op verschillende wijzen en met verschillend tempo, zonder dat daaraan een reflexieve of reciproque beteekenis verbonden is. Wordt deze vorm in de spreek- 
taal gebruikt, dan laat men veelal de persoonlijke voornaanwwoordsaanduider weg en treden daarvoor in de plaats $j o$ (als er van weinig subjecten sprake is) en $j a$ (als er van veel subjecten sprake is) :

ona kasaaríka, (ari), de een na den ander weenen;

jokasaarika, de een na den ander weenen (van weinigen);

jakasaarika, idem (van velen);

ona kasatobongíka, (tobongo), de een na den ander derwaarts zwemmen ;

jokasatobongíka, idem (van weinigen) ;

jakasatobongika, idem (van velen).

\section{Voorts :}

kasaaméka, (ame), de een na den ander ruiken;

kasaizuangíka, (wange), de een na den ander overnachten;

kasarubáka, $(r u b a)$, de een na den ander vallen;

kasasosóka, (soso), de een na den ander vliegen;

kasadagíka, (tagi), de een na den ander ergens hẹengaan;

kasadiaíka, (diai), de een na den ander vervaardigen;

kasaogoríka, (ogoro), de een na den ander ophouden;

kasalióno, (lio), de een na den ander terugkeeren;

kasapiakorika, (piakoro), de een na den ander uitelkaar gaan;

kasaroangíka, (roanga), de een na den ander blaffen;

kasagogerie, (gogere), de een na den ander zitten;

kasabataéka, (batáe), de een na den ander bewaren, opbergen;

kasaodomíka, (odomo), de een na den ander eten;

kasakibitika, (kibiti), de een na den ander spuwen; enz.

Voorbeelden en beteekenis van het voorvoegsel $\mathrm{ko}$.

Dit voorvoegsel plaatst het Tab. voor de pers. v.n.w.w. van personen en zaken en kan in het Nederlandsch het best worden weergegeven met: toch, wel, maar. Het meest wordt dit voorvoegse! gevonden bij tegenstelling of ontkenning.

ngaro tomatengóka koimodongúwa, ofschoon ik alleen ben, toch vrees ik niet;

ma i ngodózo dai koionanguzvási, doch mijn brandhoutrek daar aan zee, is toch nog niet vol;

ona janonu o pipi geéna ma kojamakézva, zij zoeken dat geld (te krijgen), doch ze krijgen 't toch niet;

kojaukuiwa, ipesa-pesakósi, 't brandt toch niet, het is nog nattig: 
takidomodongóka, kotakisebangikázva, ik ben bevreesd voor hen, ik zal maar niet meer dicht bij hen komen; manga dootasa koiaikinzade, hun boosheid is nog maar niet opgeheven;

o uku geéna koilurusiiz'a, het vuur brandt maar niet;

mongamo ikudái de kotoodomíz'a, zij kijft veel, zoodat ik maar niet eet;

o gota o fara moi ma sowoko poodomo de koposongenúz'a, er is een soort van boom, als men deszelfs vruchten eet, sterft men toch niet;

nako ngini konijainosi, tanu tinidelegade, indien jelie toch nog niet hierheen komen, zal ik jelie maar komen bezien; komoi-moiiwa jakidadanu ai ngozeaka, toch niemand, die mijn kinderen wil oppassen; (hier staat $k o$ vóór het telwoord moi).

Zeer waarschijnlijk dat dit prefix $k o$ hetzelfde is, als gevonden wordt bij de aanwijzende vnw. en bijwoorden van hoedanigheid en bij de ontkenning:

koéna, koneéna, kogeéna, kokía, konizé, koiz'a;

Ingevoegd komt ko voor tusschen de geredupliceerde objectspronomina en geeft dan te kennen, dat de handeling, aan de objecten verricht, volkomen, geheel en al plaats heeft.

Voorbeelden :

tuduku, steken, bijten; o njawa o ngootiri moi josongene, manga satarúu jokikokituduku, een prauw met menschen stierven, hun vijanden staken hen (allen) dood;

o ngia jokikokituduku, slangen beten hen (tot den laatsten toe); z'ako, gooien; joresamokáu de jokikokizeako, zij waren al binnengekomen, toen zij gegooid werden;

kiooko, slapen; ona jakikokikiooko, asa woboa, zij maften (sliepen als blokken) toen hij kwam;

uti, dalen, naar beneden gaan; o wangemaata ma fonái ikokiuti, 's namiddags (komen) de visschersprauwen alle beneden aan (d.w.z. ,van boven” = richting Ternate);

ungini, toekijken bezien; o Suuroka manga legu jokikokiungini, zij bekijken de Saoeërs hun maskeradespel;

karáu, kraken; o gota ikokikaráu manga gubalióka de manga giniraóka, veel boomen kraakten er links en rechts van hen; supu, naar buiten gaan; dai ifolói iogo-ogoro, marái o ngootiri 
ikokisupu, aan zee is het heel kalm, zeker zijn er veel prauwen (met volk) naar buiten (zee) gegaan;

dabo, wond, wonden, blesseeren; o ngoz'aka gcéna jokokidabo, die kinderen zitten geheel onder de wonden; reno, knabbelen, afvreten; o njaz'a jamuruosi-naga manga dabo ma bokeke o ligi jokikokirenóli, er zijn nog eenige lui, wier litteekens geheel worden afgeknaagd;

goli, bijten; odomo, eten; o haewani ma doróu jokikokigoli de jokikokiodomo, wilde beesten beten hen en vraten hen op.

Daar in bovengenoemde voorbeelden het objectspronomen. $3 \mathrm{e}$ ps. mv. geredupliceerd wordt, zou het niet onmooglijk zijn, dat dit ook het geval was met het subjectspronomen (meervoudsaanduider) $3 \mathrm{e}$ ps. mv.jo, dat euphonisch tot $k o$ gemaakt is : joki-joki of joki-koki, zij-zij, hen-hen; jokikokituduku, zij-zij, staken hen-hen; dus: meervoud van subject en object.

De beteekenis van het voorvoegsel $r i$.

Reeds is opgemerkt, dat van 2 of 3 personen sprekende, men voor den 3en ps. mv. als aanwijzer $i$ gebruikt, doch voor meervoud van subject jo, nl. imakangamo, zij (2 of 3 ) twisten met elkaar; jomakangamo, zij (velen) twisten met elkaar. Het Gal. vertoont in het eerste geval ri: imaringamo, zij (tweeën) twisten met elkaar.

In het Tab. wordt $r i$ gebruikt, om aan te duiden, dat vele subjecten een handeling verrichten aan objecten, die in vergelijking met de subjecten in de minderheid zijn. Wordt $r i$ geredupliceerd, dan heeft deze reduplicatie betrekking op de handeling.

Voorbeelden :

o njawa joodumu wiribaasana, alle menschen sloegen op hem; (vergel. pomakapaasana, elkaar over en weer slaan); ona miriridoana, zij schelden haar herhaaldelijk, zijn steeds op haar scheldende; (vgl. pomakakadoana, elkaar over en weer bij voortduring schelden);

jomatoómu so jokiriame, zij komen bij elkaar om hen te kussen (nl. bij terugkomst van nieuwe hadji's); (vgl. pomakaame, elkaar over en weer kussen);

o kaso magudái inarigoliokáu, een menigte honden hebben ons gebeten; (vgl. pomakagoli, over en weer elkaar bijten); jokirizuako, zij gooien hen; jokiririwako, zij gooien hen herhaaldelijk; (vgl. pomakakawako, elkaar steeds gooien); 
o ngia jokirituduku, slangen (veel) hen staken; (vgl. pomakatuduku, elkaar steken);

pomariasa, gezamenlijk iemand begeleiden, wegbrengen; (vgl. pomakaasa, elkaar begeleiden, wegbrengen); enz.

In het samengestelde voorvoegsel tubári heeft het Tab. een woord om aan te duiden, dat een handeling niet gezamenlijk, doch afzonderlijk verricht wordt, b.v. :

ona tubaritagi, zij gaan elk afzonderlijk (hun weg);

jotubariodomo, zij eten afzonderlijk (ieder op eigen gelegenheid) ;

ona tubariasa, zij brengen afzonderlijk (ieder op eigen gelegenheid, niet gezamenlijk);

jotubariwosama, zij komen de een na den ander binnen.

Zooals uit bovenstaande voorbeelden blijkt, kunnen ona en jo niet samen worden voorgevoegd.

De beteekenis van de voorvoegsels

$$
\text { tata; taba; tataba; da; dada; to. }
$$

In onderscheiding met het Gal., dat slechts het samengestelde prefix tob $a^{1}$ ) heeft, waarvan de $a$ in $b a$ zich richt naar de eerste vocaal van het werkwoord, waaraan het is voorgevoegd, heeft het Tab. de bovengenoemde voorvoegsels, waarvan de vocalen van het tweede lid zich niet richten naar de eerstvolgende vocaal van het werkwoord, doch onveranderd blijven.

tata is een reduplicatie van $t a$, dat in dezen enkelvoudigen vorm nog voorkomt in w.w., waarmee het is saamgegroeid:

$a l i$, veranderen, verwisselen; gali, veranderen in; tagali, in ruil geven voor;

1) Leiddraad blz. 87. Het hier vermelde prefix ta (en varianten) kan in woorden, die het Tab. met het Gal. gemeen heeft, als. tapádu, tibáko (Tab. tizváko), tihímo (Tab. tiimino), tjaributu, topóngo (Tab. topongono), toríhi (Tab. tirii), enz. nauwelijks meer als zoodanig gelden, aangezien dat niet meer van het w.w. te scheiden is, doch daarmee is saamgegroeid. Het Tab. heeft van deze w.w. zelfs substantieven in diimono, oudste; dadapádu, drukker; didibáko, een brok hout, waarmee men gooit; enz. 
cluku, liegen; ngeluku, leugen; tangcluku, voor leugenaar uitmaken.

badu (grndwrd. padu), tegenhouden, beletten, dat iets, iemand valt, rolt; tapadu, drukken.

Mooglijk dat $t a$ een primaire vorm is van $d a$ (zie blz. 369 en 388).

De reduplicatie van tata kan zijn: 1e. veelheid van handeling; $2 \mathrm{e}$. deelwoordsvorm :

ngamo, twisten, kijven; tatangamo, herhaaldelijk kijvende, twistende zijn; una wotatangamo kogećna, isoka wi singina iizva-izea, hij kijft herhaaldelijk zoodanig, alsof hij gek is; iete, lachten; tataiete, herhaaldelijk (om niets) lachen, giegelen; tjedeke, kamotataiete-de! jakkes, zij giegelt er maar op los! buséngi, lui zijn; tatabuséngi, luierende;

jotatabuséngi manga peda iwederokáu, zij, die luierden (luiaards). hun sago is verrot;

tosiki, stelen; wotatatosiki guuna zeilarakáu, hij, de stelende (steler), heeft men reeds gevangen gezet.

Een andere beteekenis, welke tata aan het w.w. geeft, staat vlak naast de onder 2 genoemde, wordt voorgevoegd aan afgeleide transitieven, naamwoordelijke w.w. en substantieven, welke door voorvoeging van tata tot naamwoordelijke w.w. worden gemaakt, aanduidende een toestand, waarin het subject verkeert:

odomo, eten; ngodono, maaltijd; tatangodomo, etende; mijatatangodomokási una woboa, terwijl we nog etende waren, kwam hij;

ari, weenen; gari, weenen om, beweenen; tatagari, beweenende: kanginíka jotatagarióka de wimoióli wosongene, gisteren waren zij beweenende, toen er weer een stierf;

pelesoko, moe zijn; belesoko, vermoeid zijnde van; ook: vermoeidheid; tatabelesoko, in den toestand verkeerende van vermoeidheid tengevolge van: mitatabelesookási ena momakuarene, toen zij nog in vermoeiden toestand verkeerde (tengevolge van zwaren arbeid e.d.) beviel zij;

icte, lachen; giete, belachen; ook: gelach; tatagiete, belachende: jotatagietokási o ponata jakidingotaka, terwijl zij nog aan het belachen waren, viel de daknok boven op hen.

Vergelijking : 
tatapelesoko, herhaaldelijk moe zijn; tatabelesoko, vermoeid zijnde;

tataiete, herhaaldelijk giegelen; tatagiete, belachende;

tataari, herhaaldelijk huilen, drenzen; tatagari, beweenende, ook: dreinen om;

tataodomo, herhaaldelijk eten; tatangodomo, etende;

tataeto, herhaaldelijk dronken; tatageto, bedronkende zijnde, enz.

De laatstgenoemde vormen komen voor als substantiefvormen: nanga tatangokerokási o daluku ibootóka, onze drinkerij-nogin-gang-zijnde, was de arensap op;

nanga tatadagióka, o dadoko isose, onze wandeling-nog-voortzettende, stak de wind op;

nanga tatangiduokási, o namoro itemo, onze slaap-nog-voortdurende, kraaiden de hanen.

Het samengestelde prefix taba, geredupliceerd tot tataba, aan werkwoorden en verbale adjectieven voorgevoegd, geeft te kennen: 1e. dat de beteekenis, die de voorgevoegde woorden bezitten, in verhoogden graad tot uiting komen en dat wel als een eigenschap of hebbelijkheid van het subject; 2e. deelwoordsvorm. In het Nederlandsch worden veel dezer woorden weergegeven met -ig:

babaili (van paili, meer, boven de maat) weerstreven;

tabababaili, steeds tegen den keer ingaande, altijd dwars zijn; tatabababaili, dwars zijn in den hoogsten graad;

sidemo (van temo, spreken) kennisgeven; tabasidemo, klikken, verklappen; tatabasidemo, alles aanbrengen;

tosiki, stelen; tabatosiki, stelerig van aard; tatabatosiki, onverbeterlijk diefachtig;

doisiki, bestelen; tabadosiki, gewoonte hebben om te bestelen; tatabadosiki, in den hoogsten graad;

taba wordt ook voorgevoegd bij w.w., die reeds $d a$ (en varianten) tot prefix hebben:

ami kule mitabadongosama, zij is zonder ophouden door haar boozen geest bezeten;

awi ngowaka witabadoomasa, la uwa isongene, hij houdt niet op zijn kind te beademen, opdat het niet sterve;

awi biono wokitabadaaruku, met zijn gezicht keek hij hen onophoudelijk donker (zuur) aan; (aruku, grot);

Dl. 84. 
Over de beteekenis van $d a(d \varepsilon, d i, d o, d u$,$) is reeds gesproken bij$ de behandeling van si, waar het voorvoegsel $d a$ (en varianten) gecombineerd met si aan de transitieve w.w. wordt voorgevoegd. Afzonderlijk voorkomende, geeft $d a$ (en varianten) aan de w.w. een plaatselijke beteekenis, waarvan vele door ons in het Nederlandsch weergegeven worden met be-, $\mathrm{nl}$ : beademen, bezetten, bedrukken, enz.

Voorbeelden :

ame, ruiken, kussen; daame, beruiken, bekussen; dadaame, herhaaldelijk beruiken, bekussen;

mi ngowaka modadaame, zij bekust haar kind herhaaldelijk; faáro, koortsen; dafaáro, bekoortsen $=$ koorts hebben in één huis ; dadafaáro, idem, herhaaldelijk ;

ka o woa moi geéna jodadafaáro mamoiku, dat huisgezin lijdt herhaaldelijk (in dat eene huis) aan koorts;

ese, halen; deese, halen op (iets); dedeese, idem, herhaaldelijk ; tege, druppelen; detege, erop druppelen; dedetege, herhaaldelijk bedruppelen;

tiwa, eraf vallen; ditiz'a, afvallen op; diditiwa, idem, herhaaldelijk;

siwara, schijnen, lichten; disiwara, beschijnen ; didisiwara, idem, herhaaldelijk;

omasa, ademen; doomasa, beademen; dodoomasa, voortdurend beademen ;

otana, loslaten (b.v. een vogel uit de hand); donotana, overbrengen op (b.v. luizen op eens anders hoofd) ; dodonotana, idem, herhaaldelijk ;

uisi, vloeien, lekken, druipen ; guisi, aflekken, afdruipen; duguisi, bedruipen, belekken, lekken op; azi dangiri ge o aunu joduduguisúku, van zijn slaapbank bedroop het bloed herhaaldelijk (op den grond) beneden.

De beteekenis van vele dezer w.w., welke $d a$ tot prefix hebben, staat dicht bij die van sommige afgeleide transitieven:

tooraka, overbrengen, verplaatsen, verhuizen; dooraka, verhuizen op (zelfde beteekenis als bovengenoemd donotana); pelénga, openen; belénga, openen voor, ten behoeve van; o ngorana woibelénga, hij opent het deurgat voor me; wariki, omkeeren, openleggen; dawariki, openleggen voor; o ngorana woidawariki, hij doet het deurgat voor me open; 
tege, druppelen; dege, voor, aan, op druppelen (zie detege); tosiki, stelen; dosiki, bestelen; dotosiki, stelen voor, ten behoeve van; wi aako ipiloko, siadono widosiki ma wanakowa, zijn oogen zijn blind (hij is blind), zoodat hij hem besteelt, doch zonder het te weten;

wotosi-tosiki guúna o inomo azvi ngowaka wokidotosiki, hij, die stelende, steelt eten voor zijn kinderen; enz.

Er zijn enkele voorbeelden, waarbij de vormen met $d a$ (en varianten) tot zelfst. nmww. zijn gemaakt:

diidu, slaapplaats, plek, waar vogels gewoon zijn te overnachten; van $i d u$, slapen, liggen ;

duruba, val (van een boom), plek, waar een boom valt (van $r u b a$, vallen), valzijde, tegenover galu (van alu), inkapping.

Een klein aantal zelfst. nmww. zijn samengesteld met het prefix to, (hetwelk zijn klinker niet accomodeert aan den eerstdaaropvolgenden klinker van het voorgevoegde woord, doch steeds $o$ blijft), dat waarschijnlijk een prepositie kan genoemd worden en een primaire vorm van $d o$ is. Deze vorm met to maakt in sommige gevallen het zelfst. nw. tot een werkwoordsvorm:

obiri, nacht; iobiri, 't nacht, 't wordt donker; toobiri, bij avond (nacht) komen, het avond (laat) doen worden; vervoeging als verbaal adjectief : ona jokitoobiri, zij komen bij nacht, (in westersche beteekenis) : zij komen met de nachtschuit; una witoobiri, hij idem;

biono, aangezicht; tobiono, het in iemands gezicht zeggen, zonder omwegen de waarheid zeggen.

Deze woordsoorten kunnen ook nog door do worden voorgevoegd: dotoobiri; dotobiono, enz. en hebben dan dezelfde beteekenis, welke reeds bij do (en varianten) besproken is. soana, dorp; tosoana, haan, hoen, kip; weka, Livistonia rotundifolia Mart.; toweka, met weka-bladeren iemand, (die na jaren lang weg te zijn geweest, in het dorp terugkeert) binnenhalen, feestelijk inhalen; mole, held, dappere kerel; tomole, mannelijk, als een held.

Hetzelfde to komt voor in enkele w.w. :

lomu, vergaderen, samenkomen; toomu, samenkomen, bij elkaar komen; 
osanga (als grondwoord niet meer bij het Tab. in gebruik, wel in den afgeleiden vorm sidaiosanga, Gal. wosa, vergeten); togosanga, niets meer kunnen onthouden, een leeg hoofd hebben $=$ gek.

Veel plaatsnamen op Halemahera vertoonen dit prefix to, dat wrsch. als prepositie te kennen wil geven: aan, bij.

Voorbeelden :

Tosoa (Wai. soa; Tab. soana), „Bij-t-dorp”; vgl. tosoana, haan, hoen, kip, (beest, 'dat bij het dorp behoort, dorpdier); Todow'ongi; dowongi, strand, zand; „Bij-'t-strand”;

Toguratji; guratji, goud ; „Bij-'t-goud”, een plaats, waar - zooals men zegt - in het riviertje stofgoud gevonden wordt;

Todahe; dahe, Tern. bereiken, treffen, raken (Tab. daene); „Bij-halen”, ,'t Nog-halen” (plaatsnaam van de eenige prauwankerplaats op de Westkust) ;

Tongute ; ngute, trap, ladder ; „Bij-den-trap”;

Tongodowo; ngodowo (van dowo, rook), brandhoutrek; „Bij't-brandhoutrek";

Todoke; doke, ginds, aan den over-, buitenkant;

Toguisi; guisi, afdruipen, aflekken (van uisi, lekken);

Toguaere; Wai. guaere, Tab. guaze, mangga;

Toweka; weka, waaierpalm;

Togosi; gosi, ei ; enz.

Mooglijk dat deze prepositie dezelfde is als die bij de pers. vnww. gebruikt worden om deze in bezittelijke te veranderen:

tongoi, van mij; touna, van hem; toona, van hen, enz. (zie bij de bezitt. vnww.).

In tanauru (nauru, man), middelste vinger; heeft de $o$ van to zich toch weer geaccomodeerd aan den eerstvolgenden klinker van het bepalende woord, terwijl in tongeweka (ngeweka, vrouw), ringvinger; de $o$ zich gehandhaafd heeft, omdat in de aanverwante talen de eerste lettergreep van het woord voor ,vrouw” ngo is en het Tab. nge wellicht een nieuweren vorm vertoont.

Wat de beteekenis is van het prefix to in namen van enkele volksstammen op Halemahera, zooals Tobaru (deze stam noemt zichzelf Tabaru; het Tern. en andere dialekten hebben: Tobaru); Tobelo; Togutil, is moeilijk te gissen. Men heeft dit wel eens in verband 
gebracht met het to van de talen in M. Celebes: To Radja, To Pebato, enz. doch verwantschap schijnt vrijwel uitgesloten.

De imperatief wordt niet gevormd, zooals in het Mal. en Nederlandsch: panggil! roep! Een Tab. werkwoord zonder persoonsexponent zegt niets: asoko! is niet: roep!, maar wel: noasoko! gij roep!; nijotagi! gij (mv.) gaat! Uit den toon van spreken moet opgemakt worden of het een imperatief- dan wel een indicatiefvorm is; nooara, is evengoed: loop! als: gij loopt. Dit onderscheid is gemakkelijk genoeg waar te nemen, vooral als een bevel bovendien nog vergezeld gaat van ika! toe, vooruit!; taiti! vlug wat!; ino! herwaarts! B.v. ika, nooara! toe, loop! taiti, naese! vlug, haal 't! ino, noiriwo! kom hier, help me! o Gura woniasokino! roep Goera hierheen! enz.

De votatief wordt gevormd met uzwa, dat zoowel beantwoordt aan de beteekenis van het Mal. djangan, als aan de Mal. ontkenning tidak of tiada, met dit verschil, dat de verbiedende wijs uwa plaatst vóór den zin, terwijl de ontkenning uw'a maakt tot achtervoegsel, dat als zoodanig soms verkort wordt tot wa. Uwa nodoa! klim niet! uwa nijoudjara! lummel jelie niet! uz'a jagoraka! laten ze dat niet opnemen! enz.

Wordt de praeteritum-aanduider ou aan $u w a$ achtergevoegd, dan wil dat zeggen: opdat al niet, opdat niet meer: uwau towosama! laat af, dat ik meer binnenkome! opdat ik al niet meer binnenkome!

De ontkennende vorm ,neen” is: ko + ure'a $=$ kouwa. o peda wonikula? heeft hij sago aan je gegeven? kouwa! neen! - ne ani w'ase, hier is je hakmes; kouwa, tongoizwa, neen, van mij niet (dit is het mijne niet).

isauku ma kouzva, imaata ma kouz'a, kaialo-alo, het is niet warm, het is niet koud, het is slechts kil.

Er ,niet zijn” is : iwa; o igono iizwa, klappers, ze zijn niet (er zijn geen klappers); o igono koiiwa, klappers zijn er (als 't ware toch) niet; o igono koiizwaka, klappers zijn er in geen geval meer; o igono koiizwakau, klappers zijn heelemaal reeds op $(k o+i+i w a+o k a$ + ou $=$ koiizwakau).

Aldus wordt ook kouwa met de aanduiding van het praeteritum 
ou tot kouwau, al, reeds neen; (Mol. Mal. soedah trada of soe-trada). izva geeft aan de ps. vnww. dezelfde vormen als aan de telwoorden en verbale adjectieven: ngona niiwa, jij je was (bent) er niet; una wiizwa, hij, hij was (is) er niet; ona jokiiz'a, zij, zij waren (zijn) er niet; komoiizua, niemand was (is) er.

\section{De achtervoegsels.}

Reeds is opgemerkt, dat het ontkennende $u$ w $a$, niet, als achtervoegsel voorkomt. Het hecht zich zoowel aan werkwoorden als aan naamwoorden en verliest bij alle woorden, die den klemtoon op de vóórlaatste lettergreep hebben het eerste lid, n.l. de $u$, welk lid evenwel bij woorden, die de derde lettergreep van achteren accentueeren, behouden blijft, ofschoon ten koste van de laatste vocaal van het aanhechtingswoord, onverschillig welke vocaal dat is. De klemtoon, die het woord heeft, verplaatst zich na aanhechting op de voorlaatste lettergreep.

Voorbeelden :

wosama, binnengaan; wosanúa'a, niet, enz.

pagara, op den buik liggen; pagarúzua, niet, enz.

sofála, ijverig; sofaláwa, niet, enz.

idja, koopen; idjárwa, niet, enz.

resene, uit den weg gaan; rescnúz'a, niet, enz.

make, zien, vinden, verkrijgen; makéw'a, niet, enz.

pidili, losmaken; pidilúwa, niet, enz.

taári, staan vóór; taaríz'a, niet, enz.

tagi, gaan; tagiwa, niet, enz.

odomo, eten; odomúwa, niet, enz.

bodito, een ongeluk hebben; boditórua, niet, enz.

oko, staan; okówa, niet, enz.

punusu, verzadigd; punusírua, niet, enz.

$u k u$, branden; ukúwa, niet, enz.

o tonaóka geéna o bonganúzia ma ka o nguusumu, in dat land is geen bosch, enkel alang-alang;

geéna o dofaézé ma o golopúngu, dit is geen kalk, maar meel.

Wordt de aanwijzer van het praeteritum ou achter de ontkenning uw'a gevoegd, dan valt de $o$ van ou weg, terwijl de voorlaatste lettergreep den klemtoon krijgt: 
parenuwáu $=$ parene, bestijgen, $+u w r$, niet, $+o u$, al, reeds niet meer bestijgen;

totagizuáu, ik ga al niet meer ;

tookcruźáu, ik drink niet meer.

Teneinde de ontkenning stelliger te maken, wordt deze geredupliceerd :

towosamuwazwáu, $($ to + wosama $+u z v a+u w a+o u) \mathrm{ik}$ ga al niet meer binnen, ik ga volstrekt niet meer binnen;

o titi joodomuz'awáu, zij eten in het geheel geen varken(svleesch) meer ;

una zoisingounuwawóa, hij, hij al in het geheel geen rekening meer met mij houdende.

Dit achtervoegsel bij naamwoorden: una, ka o njaz'awáu, hij is geen mensch meer; ipululunuzváu, het is niet rond meer.

\section{Het suffix ok a:}

In het Gal. is $k a$ de aanduider van den verleden tijd. In het Tab. evenwel is oka zonder meer niet voldoende om een handeling als geschied zijnde, als in het verleden voor te stellen. Daartoe is noodig, dat het boven besproken ou achter oka gevoegd wordt tot oka + $o u=o k a u$. Wordt oka alleen achtergevoegd, dan wil dat zeggen, dat de handeling geschied is, geschiedt, verricht wordt of duidt een toestand aan bij naanwoordelijke werkwoorden. De beteekenis van ou zonder $o k a$ als achtervoegsel is : bereids, reeds, al.

Wij krijgen dus :

potagi, gaan;

potagióka, ging;

potagióu, bereids gaan, gaande, in gang zijn;

potagiokáu reeds gegaan;

w'oiscne, hij hoort;

woisenóka, hij hoorde;

woisenóu, hij hoort al ;

woisenokáu, hij heeft reeds gehoord;

jotumunu, zij duiken ;

jotumunóka, zij doken;

jotumunóu, zij duiken al ;

jotumunokáu, zij hebben reeds gedoken. 
Het imperfectum wordt dus weergegeven door $o k a$; het perfectum door $o u$ en het plusquamperfectum door okau.

kangáno ni woáka towosama, cna ni tupa tamakekáu, zooeven ging ik je huis binnen en zie, daar heb ik je pinangdoos gevonden. (Het is onnoodig achter wosama het imperfectum oka te voegen, aangezien kangáno (zooeven) reeds het verleden der handeling ,binnengaan" te kennen geeft).

mi ngowaka wosongenóka de ma csa momazuatonóka, haar kind is dood en z'n moeder is naakt (ontdoet zich van kleeren vanwege haar smart);

nanga manarama iraiokáu, so potagióu, ons werk is reeds af, dus laten we bereids gaan;

ato ibesakóu, 't wil reeds gaan regenen, 't zal niet lang meer duren of 't regent reeds;

ade waadonóu, hij was er bijna;

o wange neéna woweletáka, vandaag is hij aan 't sagodisselen; doka o tonaka mopaitóka, dáár is zij aan het grondgraven;

ani bole taesekáu, je pisang heb ik reeds gehaald;

matuwangeróu todoimokáu, al voor de achtste maal heb ik reeds geteld.

Wat over de verplaatsing van den klemtoon gezegd is, geldt ook voor $o k a$, ou en okau. Trouwens ook bij alle andere nog volgende achtervoegsels hebben de woorden steeds den klemtoon op de voorlaatste lettergreep. De $o$ van $o k a$ valt weg na tweelettergrepige woorden met eindvocalen $a, c$ en $o$. De bovenland-Tabaroe hebben de neiging de sluiter $k$ na aanhechting van het suffix oka te laten vallen. Die verloren $k$ wordt dan weer in oka hersteld. De benedenlandTabaroe behouden dezen sluiter.

Voorbeelden :

iotaka, het valt; iotaokáu; iotakokáu, het is reeds gevallen; isowoko, 't draagt vruchten; isowookáu; isozeokokáu, 't droeg reeds vruchten;

mosingowaka, zij baart; mosingoz'aokáu; mosingowakokáu, zij heeft reeds gebaard;

wopelclaka, hij is mager; wopclelaokáu; wopclelakokáu, hij is reeds vermagerd;

Voorts :

osiki, baden; osióka; osikóka; 
toteke, kloppen; toteáka; totekóka ;

iriki, uitzoeken; irióka; irikóka; enz.

De aanduiders van het praeteritum worden door de volgende woorden vervangen:

booto, op, gedaan; rai, klaar, gereed, af ; duanga, afgeloopen.

Deze woorden zijn werkwoordsvormen, welke met pers. vnww. kunnen vervoegd worden en ter versterking verbonden worden met okau: bootokáu; raiokáu; duangokáu.

zuatodanga wabooto, hij omkapt, hij gedaan (is met omkappen gereed); watodanga wabootokau, hij is met omkappen reeds klaar gekomen;

wi peda waweléta z'arai of waaraiokáu, zijn sago, hij disselt, hij heeft het afgemaakt;

wopeoto woduanga of woduangokáu, hij arensap tapt, hij heeft het reeds doen afloopen.

Voorts: ibootóu; iraióu; iduangóu, al klaar, af.

Het suffix osi beteekent, ,nog” en beantwoordt aan het Mal. lagi. De $o$ van $o s i$ valt weg na tweelettergrepige woorden met eindvocalen $a, e$ en $o$ :

okere, drinken; okerósi, nog drinken;

iete, lachen; ietósi, nog lachen;

tike, zoeken; tikési, nog zoeken;

ese, halen; esési, nog halen;

paasana, slaan; paasanósi, nog slaan;

kula, geven; kulási, nog geven; enz.

ngoi o ngow'akósi, ik, nog een kind zijnde;

o ngowakinósi, nog omtrent een kind zijnde (ino + osi);

o doguuruósi, nog een jongeling zijnde;

o pokorukósi wopiloko, vanaf den buik (geboorte) is hij blind $=$ blindgeboren (pokoro $+u k u+o s i)$; enz.

De ontkenning $u w a+o s i=u w^{\prime} a s i$ is in beteekenis gelijk aan het Mal. beloem, nog niet;

totagizuási, ik ga nog niet, ik ben nog niet gegaan; notoimuzúasi? heb je nog niet gepijld? kouzwási! nog niet!

Het suffix oka + osi $=$ okási en geeft aan de handeling de beteekenis van: nog eerst, eerst nog: 
potuluokási, eerst nog aanloopen, aangieren;

poidjakási, eerst nog koopen;

az'i ngootiri wadiaiokási, hij maakt z'n prauw eerst nog in orde; tomokurokási, asa totagi, ik zal eerst nog pruimen, dan zal ik gaan.

Het suffix oli beteekent: weer:

wooaróli, hij loopt weer weg;

moelukóli, zij liegt weer;

joliosáli, zij keeren weer (landwaarts) terug $(l i o+i s a+o l i)$; ibcsakóli, het regent weer;

o pipi woikuláli, hij geeft me weer geld;

mogiookóli jadogo, zij doen er weer tien bij;

mamoióli, nog een keer;

De achtervoegsels oka en ou in verbinding met oli:

$o k a+o l i=o k a ́ l i ; o k a+o u+o l i=$ okauóli $:$

o bonganóka wogogerokáli, hij zat alweer in het bosch; wogogerokauóli, idem, reeds weer;

jodadamokáli, zij waren alweer aan 't levenmaken; jodadamo-

kauóli, zij waren reeds weer aan 't levenmaken;

ibesaokáli of ibesakokáli, het regende weer;

ibesaokauóli of ibesakokauóli, het was reeds weer aan 't regenen.

Het ontkenningssuffix $u w a+o l i=u w a ́ l i$, weer niet;

uz'a $+o u+o l i=$ uwauóli, al reeds weer niet;

wamotckuwáli, hij gaat weer niet mee;

wamotckuwauóli, hij gaat al weer niet mee;

nijoisenuwáli? hoort gijlieden weer niet?

nijoisenuwauóli, hoort gijlieden al reeds weer niet?

Al deze achtervoegsels behooren onder de bijwoorden. Tot deze laatste kunnen ook de volgende gerekend worden, welke tevens rich. tingaanduidende woorden zijn :

ino, hierheen, herwaarts;

now'osamino, kom herwaarts binnen;

wacséno, hij haalt 't hierheen, herwaarts;

$i n o+o s i=$ inósi $;$ ino + oli $=$ inóli $;$ ino + oka $+o u+o l i$

= inokauóli:

jaasanósi, zij brengen 't nog hierheen;

jaasanóli, zij brengen 't weer hierheen; 
jaasanokauóli, zij hebben 't reeds weer herwaarts gebracht.

Vervoeging :

una waino, hij (komt) hierheen;

una wainóu, hij (komt) al hierheen;

una rainokáu, hij is reeds hierheen (gekomen);

$i k a$, daarheen, derwaarts :

nosiresenika, zet 't derwaarts uit den weg;

nijooarika, loop hard derwaarts heen;

$i k a+o s i=i k a ́ s i ; i k a+o l i=i k a ́ l i ; i k a+o k a+o u+o l i$ = ikakauóli.

Vervoeging :

muna maika, zij (gaat) derwaarts;

muna maikáu, zij (gaat) al derwaarts;

muna maikakáu, zij is reeds derwaarts (gegaan);

$i s a$, landwaarts; dina $+i s a=$ dinaisa, dáár, aan den landkant; z'oliósa, hij keert naar den landkant terug; $i s a+o s i=i s a ́ s i ; i s a+o l i=i s a ́ l i ; i s a+o u+o l i=$ isauóli.

\section{Vervoeging :}

ona jaisa, zij (gaan) landwaarts;

ona jaisáu, zij (gaan) al landwaarts;

ona jaisakáu, zij zijn reeds landwaarts (gegaan);

oko, zeewaarts; dai + oko $=$ daióko, dáár aan zee;

$i e$, bovenwaarts ; daku $+i e=$ dakuic, dáár boven ;

$u k u$, benedenwaarts; dau $+u k u=d a u k u k u$, dáár beneden:

Ook deze woorden kunnen dezelfde achtervoegsels hebben en vervoegd worden op gelijke wijze als bovengenoemde.

De ontkenning uwva staat achter deze woorden, hetzij deze als werkwoorden of als achtervoegsels voorkomen:

zuainówa, hij (komt) niet hierheen; wainoz'áu, hij (komt) niet meer hierheen;

naadoniézwa, je kunt er boven niet bijkomen $(n a+a d o n o+i c$ + uwa)

awi singina iomangiézva, zijn verstand is niet tot boven toe vol; o bonganisázwa jowosama ma o nguusumika, zij gingen niet landwaarts het bosch in, maar ginds de alang-alang in; 
daukíku waukúwa ma waiéno, daar beneden ging hij niet benedenwaarts, doch hij kwam bovenwaarts hierheen;

jobitjara josiado-adonikárca, zij komen met hun spreken er niet aan toe (zij weten hun woord niet te doen).

Een tweede beteekenis van is en $u k u$ is: een verhoogde graad, geheel en al, van top tot teen :

wotaro-taromí, hij is in-zwart; o are-aresíc, de spierwitten

(Hollanders) ; kamamoíku, ten eenemale;

josongenúku, zij stierven allen zonder uitzondering; enz.

\section{Substantieven.}

Behalve de onderscheiding van de geslachten mannelijk en vrouwelijk bij familiebetrekkingen, kent het Tab. geen woordgeslacht. De woorden om mannel. en vrouwel. individuen te benoemen, toonen hun geslacht bij de handeling, die door hen verricht wordt, terwij! de vrouwel. eigennamen van die der mannel. zich onderscheiden door voorvoeging van den aanwijzer ngo, welke nog weer wordt voorafgegaan door den zelfstandignaamwoordsaanwijzer $o$, hoewel deze laatste in de spreektaal meestal verwaarloosd wordt.

djodjo zonder partikel ter nadere geslachtsaanduiding (aldus in den vocativus) kan wezen, 1e oom, jongere broer van vader; 2e, tante, jongere zuster van moeder; $3 \mathrm{e}$. schoonvader van de vrouw; $4 \mathrm{e}$. schoonmoeder van de vrouw. In het $1 \mathrm{e}$ en $3 \mathrm{e}$ geval moet het geslachtspartikel dus worden: o djodjo; in het $2 \mathrm{e}$ en $4 \mathrm{e}$ geval: o ngo djodjo.

o ngo apu mi dou mosisouru, grootmoeder medicineert haar been. Vocativus: $a p u$, noidamaasi! grootmoeder, wacht op me! $o$ aba $o$ dowongiokoka wosupu, vader is naar het strand gegaan. Vocativus: $a b a$, o daluku macta! vader, (geef me) een beetje arensap!

o ngowaka zvimoi wotagi wodjaa, een kind, 'n hem, hij ging, hij netwerpen;

o ngowaka moi moscsara, een kind, zij veegde.

Uit deze voorbeelden blijkt, dat een nadere aanduiding van het geslacht ,kind" overbodig is.

Is geslachtsonderscheiding dringend noodig, dan zegt men: $o$ ngo- 
waka o nauru, kind-man, jongen ; o ngowaka o ngewéka, kind-vrouw, meisje.

Mannel. eigennamen: o Koránjo; vrouwel. eigennamen: o ngo Susugara.

Het Tab. heeft geen algemeenen naam voor ons ,broer” en „zuster”. „Zijn zuster” is : awi biranga ; ,z'n zuster” is : ma biranga ; „,haar broer" is : ami iranga; ,,'r broer" is : ma iranga. Voorts onderscheidt het Tab. evenals het Mal. van beide geslachten ,oudere” en ,,jongere” broer en zuster : o ngo Ragáne ma riaka, Ragane's oudere (zuster); blijft de naam weg, dan wordt ter nadere aanduiding gezegd: ami riaka, háár oudere (zuster).

o Pigu ma riaka, Pigu's oudere (broer);

o ngo Buséngi ma dodoto, Busengi's jongere (zuster);

o Rosa ma dodoto, Rosa's jongere (broer); enz.

Voor geslachtsaanwijzers bij dieren en enkele boomen en planten: ma nauru (Mal. djantan), mannetje; ma bedéka (Mal. betina), vrouwtje.

o boki ma nauru, kater; o kaso ma bedéka, teef ; enz. ,Jong” in 't algemeen is: ma ngow'aka: o titi ma ngowaka, big; o djara ma ngowaka, veulen; o namoro ma ngowaka, kuiken.

Aangezien ma ngowaka ook een sali (wisselwoord) is voor ma gosi, ei, welk laatste woord tevens een verbloemde uitdrukking is voor testes, spreekt men nooit van o namoro ma gosi, kippenei, doch neemt voor „ei”: ma ngozvaka of het Tern. boro, ei : o namoro ma boro of : o namoro ma ngowaka, kippenei.

Om deze zelfde reden eischt de wellevendheid, dat men nooit zegge: o Beláha ma ngowaka, want dat zou niet zijn „Belaha's kind”, doch „Belaha's jong” of „Belaha's testes”. (Het Gal. heeft wel ma ngopa). Men moet dus zeggen: o ngo Gisísi mi ngowaka, Gisisi haar kind, en: o Masi wi ngozvaka, Masi z'n kind.

De genitiefvorm $m a$ wordt overigens, zooals reeds is aangetoond, bij alle familiebetrekkingen gebruikt, zelfs bij "z'n” of ,'r moeder": ma esa, hoewel deze benaming ook kan beteekenen ,vrouwtjesvarken”, ,zeug” en ,,vrouwtjeshert” (voor welke beide benamingen geen bedéka gebruikt wordt) en in 't algemeen „moederdier” beteekent.

o titi ma esa of alleen ma esa, vrouwtjesvarken, zeug;

o boki ma esa, moederkat; o Dopu ma esa, Dopoe's moeder. 
Alleen voor ,mannetjesvarken”, ,beer” heeft men ma makoro.

Het Tab. kent geen meervoudsvorm, zooals wij die bezitten; o woa kan zijn: „huis” en „huizen”; o njaw'a, „,mensch” en „menschen”; o gota, ,boom” en ,boomen”. Uit den zin moet het enkel- en meervoud blijken. Zegt men: o wase tonikula, dan kan dit beteekenen: ik geef je 'n hakmes, en: ik geef je hakmessen. Evenzoo: o kaso tapaasana, ik sla 'n hond, en: ik sla honden. Bij beide laatste voorbeelden zou het dus noodig zijn, nadere aanwijzing voor het getal te geven, ware het niet, dat men gewoon is, zich zoo concreet mooglijk uit te drukken, door te spreken over onderwerpen, die bekend verondersteld worden en om die reden alle omschrijvingen vermeden worden. Geeft men dus niet door een te benoemen getal den meervoudsvorm aan, dan weet ieder, dat er ,'n hakmes gegeven wordt" of ,'n hond geslagen wordt". Anders wordt dit, wanneer het voorwerp van handeling personen geldt, want dan komt enkel- en meervoud positief voor den dag: o njaz'a tokimake, ,menschen, ik hen (eenigen) zag", aangezien door de invoeging van de objectexponent 3e ps. mv. $k i$, duidelijk die meervoudsvorm wordt aangegeven. Nog: $o$ njawa takibau, ,menschen, ik hen (velen) leen = roep om mij te helpen".

Zoo ook met het enkelvoud: o njawa torvisuloko, ,'n mensch,, ik hem opdraag”; o njawa tomiasoko, ,'n mensch, ik haar roep”.

Het te bepalen getal van het subject in den zin wordt (als het menschen geldt) door de subjectsexponent duidelijk aangetoond: o Tjináka of : o Tjináka ma njazva jomazunkunu, China-menschen (Chineezen) zij verkoopen; o Tịináka of: o Tjináka ma njar'a imazukunu, idem van eenige personen; o Tjináka of : o Tjináka mc njawa wolutuokáu, 'n Chinees, hij is verdronken.

Daarentegen bij dieren en zaken :

o kaso iodomo, de hond eet, de honden eten;

o boki ioara, de kat loopt weg, de katten loopen weg.

Verder blijkt enkel- en meervoud en geslacht uit het gebruik der bezittelijke voornaamwoorden; zie bij „Woordherhaling en Reduplicatie".

Samengestelde zelfst. n.w.

o dou-bedere (dou, voet; bedere, van zedere, stukgaan), naam van een zwam, welks sap de huid aantast; 
o namo-nanási (namo, kip, vogel; nanási, ananas), naam van een japansche kip, welker veeren overeenkomst vertoonen met de ananasschil;

o pipi-duka (pipi, geld; duka, wrsch. van Mal. toekar, ruilen of docka, verdriet), naam van Haantjes- en V.O.C.-duiten;

o sumáti-baru (sumáti, rijksdaalder, vgl. „mat” (spaansche); baroe, Mal. nieuw), dollar;

$o$ dudu-esa (dudu, achter (Tern.) ; esa, oorsprong, moeder), ruggewervel ;

o mokuru-teda (mokuru, betel; teda, uitstallen), naam, waarmee ,gambir" wordt aangeduid;

o ngowaka-dowo (ngowaka, kind; dow'o, verpleging), pleegkind;

o galu-ze'ewe (galu, voorliggend, van alu; wewe, oom), voorouders;

o csa-moi (esa, moeder; moi, een), moeder-een =- van één moeder, naam, waarmee stamgenooten worden aangesproken;

o dea-bobáu (dea, vader; bobau, van bau, leenen, in gebruik nemen, stief), stiefvader; enz.

\section{Afgeleide substantieven.}

Het Tab. heeft een aantal substantieven, welke onveranderd in werkwoordsvorm kunnen optreden:

nanere, droom; droomen; sugara, schop, krabber; uitglijden; songene, lijk ; doodmaken, sterven ; manarama, werk, arbeid ; werken, arbeiden; tounu, ei van de boschkip (wisselwoord) ; ophoopen; kinitara, licht; licht zijn, licht worden; palusu, echo ; antwoorden ; tonaka, land; ebben, vallen van het water $=$ zichtbaar worden van het land; dobele, de vloed; opkomen van den vloed; morene, verheuging; verheugd zijn; idja, koopprijs; koopen; amoko, grootte; groot zijn; owa, goedheid; goed zijn, enz.

De meeste afgeleide substantieven zijn van primaire w.w. afgeleid; sommige van adjectieven. Wat bij de afgeleide w.w. gezegd is over de verandering van de tenues in mediae, geldt ook bij de van w.w. afgeleide substantieven:

bairi, akker; van pairi, ontginnen;

boosuku, graf; van poosuku, begraven;

busuku, bindsel, pak; van pusuku, binden ;

barene, opkomst (van de maan); van parene, opkomen; 
beléta, het sagodisselen; van weléta, sagodisselen;

beoto, het arensaptappen; van peoto, tappen;

booteke, bron; van pooteke, breken, splijten;

balusu, volwassene; van palusu, antwoorden;

bidili, het losgelatene, loslater; van pidili, loslaten;

barene, restant, het overschietende; van parene, voorbijgaan, resteerend;

besesongo, bevel; van wesesongo, bevelen;

benga, pols; van penga, kloppen van de pols, polskloppen;

bedere, het stukkende, het kapotgegane; van a'edere, stukgaan;

donga, kier, reet; van tonga, van elkaar wijken;

diái, vlakte, dal; van tiái, vlak-, gelijkmaken;

$d j o b o$, een greep, 'n handvol van; van tjobo, vastgrijpen;

darusu, schaduw; van tarusu, donker zijn, worden, donkeren;

demo, woord, gezegde; van temo, spreken, zeggen;

dino, weefsel; van tino, weven;

dege, drup, druppel ; van tege, druppelen;

diikiti, hoest; van tiikiti, hoesten;

dingásu, helling; van tingásu, afhellen ;

donaka, eb; van tonaka, 't ebt, 't land wordt zichtbaar;

diwa, het afgevallene (van vruchten); van tiwa, afvallen;

detoro, het afgepikte, restje; van tetoro, afpikken;

dagáli, plaatsvervanger; van tagáli, in de plaats geven voor. ruilen;

$d u l u$, het overeenkomstige, het meest nabijkomende; van tulu, aanloopen, aangieren;

deturu, de door de van het dak afdruipende regenstralen uitgeholde, afgebrokkelde plaatsen rondom het huis; ook: het overstekende dakgedeelte; van teturu, afbrokkelen;

damumu, trom (het overdekte); van tamumu, dekken, overdekken;

dakoro, het geklop; van takoro, kloppen;

dadoko, wind; van tadoko, waaien;

ginitara, erf (het opengekapte); van kinitara, licht worden, open zijn;

gudóti, oorlog; van kudóti, oorlogen ;

gimina, deel; van kimína, verdeelen ;

gosiki, bad, badwater; van osiki, baden;

guriti, het aangeregene; van uriti, aanrijgen; 
gutuku, padi-mesje; van $u t u k u$, padi-snijden;

gari, geween; van ari, weenen;

goóo, uitspruitsel; van oo, leven, uitspruiten;

goo, groei; van oo, leven, groeien;

getongo, scheur; van etongo, scheuren ;

galu, inhak bij te vellen boomen; van alu, inhakken aan den

valkant;

guríe, begin; van kurúe, beginnen, aanvangen;

gudara, het wieden; van udara, wieden;

nagimi, schuld; van (Tern) hagi, schulden maken, poffen;

noboso, zucht, dikte; van oboso, zuchtig, gezwollen;

ngasiri, slok; asiri, slikken;

ngodomo, maal; odomo, eten;

ngokere, drinkgelag; okere, drinken;

ngunisi, bandjir; uisi, overstroomen;

ngomasa, adem; omasa, ademen ;

ngomasa, strottenhoofd; omasa, ademen;

ngogoro, drooge moesson; ogoro, ophouden;

ngogu, stuk, brok; ogu, afsnijden;

an adjectieven:

beréki, oudje; peréki, oud zijn;

belelaka, magerte; pelelaka, mager zijn;

baili, restant, overschot; paili, over-zijn, teveel;

bolói, idem; folói, meer;

belesoko, vermoeidheid; pelesoko, vermoeid;

diimono, bejaarde; tiimono, bejaard zijn;

dubúso, zwaarte; tubúso, zwaar;

debini, reinheid; tebini, rein, schoon;

dootasa, kwaadheid; tootasa, kwaad zijn;

dingoono, kleinheid; tingoono, klein;

daromo, het zwart; taromo, zwart, donker (van kleur);

dereboko, het roode; tereboko, rood;

debeturu, luiheid; tebeturu, lui ;

guata, kracht, sterkte; kuata, sterk-, krachtig zijn;

guusaka, ichtyosis; kuusaka, schurftig;

gipirini, dikte; kipirini, dik zijn;

guarene, licht, het lichte (tegenover zwaarte); kuarene, licht zijn;

gakuru, hoogte, lengte; kakuru, lang, hoog ;

gurutu, verte; kurutu, ver;

Dl. 84. 
gomuku, het rijpe, rijpte; omuku, rijp ;

gou, onrijpheid; ou, onrijp;

garese, het wit; arese, wit;

guráti, curcuma; kuráti, geel ;

gubáli, linkerkant; kubáli, links ;

goosisi, wees, (in: o ngowaka o goosisi, weeskind) ; van koosisi,

schraal, mager, er ongezond uitzien van boomen, planten, die

teveel in de schaduw staan, woordelijk: eruit zien alsof 't ,bepist” is, van osisi, pissen; enz.

Geredupliceorde substantieven, afgeleid van werkwoorden en duiden aan het voorwerp waarmee de handeling verricht wordt:

dadadoko, vuurwaaiertje; dadoko, wind ; tadoko, waaien ;

dadamunu, bedekking, overdekking; damunu, trom (wat over-

dekt is) ; tamunu, bedekken, overdekken;

dadakoro, klopper; dakoro, geklopt ; takoro, kloppen ;

babaasana, geesel, knuppel; baasana, gegeesel, slaag; paasana, slaan ;

bubusuku, band, verband; busuku, pak, bindsel; pusuku, binden ; bebeléta, sagodissel; beléta, sagoarbeid; z'eléta, sagoarbeiden;

bibikiri, zeef ; pikiri, zeeven ;

gigikiri, afveger, dweil ; ikiri, afvegen, uitwisschen ;

(Zie verder sub 3 bij Woordherhaling en Reduplicatie).

\section{Woordherhaling en Reduplicatie.}

Van volledige woordherhaling kan alleen sprake zijn bij tweelettergrepige naamwoorden en werkwoorden, terwijl bij de woorden, welke meer dan twee lettergrepen tellen, een gedeeltelijke woordherhaling optreedt. Hoewel vormelijk van elkaar verschillend, komen beide vormen in beteekenis met elkaar overeen, vandaar dat niet elke vorm afzonderlijk kan behandeld worden.

\section{Substantieven.}

1. Bij de aanteekeningen van deze woordsoort is opgemerkt, dat het Tab. geen meervoudsvorm bezit, zooals wij die kennen. Toch heeft men in enkele gevallen een meervoudsvorm, welke door reduplicatie van de eerste twee lettergrepen gevormd wordt. Dit zijn de z.g. collectieven, waarvan slechts enkele vorbeelden voorhanden zijn: 
ngowaka, kind, kinderen; ngowa-ngowaka, nakomelingen;

dangono, kleinkind, kleinkinderen; dango-dangono, nazaten, afstammelingen, nageslacht;

balusu, volwassene, volwassenen; balu-balusu, al de volwassenen van een dorp tezamen;

saeke, hoofd, hoofden; sae-saeke, al de hoofden van een land of gewest;

o Tonakamaesa ma sae-saeke jomatoómu, al de hoofden van Halemahera komen tezamen;

o Sabói wi ngowa-ngowaka o dekúka jomagogogere, het nageslacht van Saboi (Tabaroe-stamvader) heeft zich op de bergen gevestigd.

2. De volgende voorbeelden geven te kennen: gelijkende op de door het oorspronkelijk substantief uitgedrukte beteekenis:

gosomanga, krokodil; gogosomanga, schapenwolkjes (gelijkende op de geschubde huid van den kaaiman);

ngootiri, prauw ; o ngongootiri, miniatuurprauwtje, ook: de holle zijde van den sagopalm-bladsteel;

o ugaka, suikerriet; o uga-ugaka, e.s.v. riet, gelijkende op suikerriet (geen Saccharum spontaneum L. d.i. kakanoko);

o bidoso, betel; o bido-bidoso, een boschvrucht (Piper miniatum B1.) gelijkende op betel ;

o tabáko, tabak; o tatabáko, een plant, welks blad op het tabaksblad gelijkt;

o igono, kokospalm; o igo-igono, een daarop gelijkende kleinere palm (Gal. gogopóa; Tern. sibu-sibu); Cyathea arborea Sm.

o giama, hand, arm; o gia-giama, de arm van de inheemsche viool ;

o sinapani, snaphaan, geweer; o sisinapani, kindergeweertje;

o sidete, zeil (v.e. prauw); o sisidete, oorschelp;

$o$ sidele, hanger, hangertje; o sisidele, oorlelletje;

o ngodóz'o, brandhoutrek, rookrek; o ngongodów'o, sleutelbeen;

o sowoko, vrucht; o sosowoko, hiel van den voet; o sowosowoko, vruchtmotief in snijwerk;

o liwanga, gong, bekken; o lizua-liwanga, groene tor (die op lamplicht afvliegt en bromt als een gong);

o ngia, slang; o ngia-ngia, nagemaakte slang, motief in snijwerk;

$o$ kaso, hond; o kaso-kaso, hondenbeeldje, nagemaakte hond; 
$o$ woa, huis; o woa-zoa, huisje (speelgoed);

o namoro, hoender, vogel; o namo-namoro, nagemaakte vogel;

o njar'a, mensch; o njaroa-njaz'a, prent, beeld, pop.

3. Van werkwoorden afgeleide substantieven, aanduidende het voorwerp, waarmee de handeling verricht wordt:

gegesaka, wisscher, strijklap; esaka, wisschen, strijken;

dadapádu, drukker, een ding om te bezwaren; tapádu, drukken, bezwaren;

dudutuku, stamper; tutuku, stampen; gagasidele, wieg, d.w.z. een aan balk of spant opgehangen sarong, waarin het kind ,opgehangen” wordt; dus eigenlijk: „ophanger”, van kasidele (posikasidcle, eraan doen hangen) van sidele, hangen;

dadázvi, wimpers; tazvi, oogknippen; ngingitiri, slaap van het hoofd; itiri, bewegen;

gigiete, de 4 voorste tanden, die bij het lachen zichtbaar worden, dus : „lachers”, van iete, lachen;

sasanguru, neus (wisselwoord voor ngumunu); sanguru, snuffen; snuiven;

dudumutu, vingers (wisselwoord voor rarága); tumitu, wijzen; gogonoko, plaats, waar water gehaald wordt; onoko, waterhalen; sasakái, kookplaats, keuken; sakái, koken; susugara, lepel; sugara, lepelen, opscheppen; sesesara, bezem; sesara, vegen; sisífo of sisíwo, knuppel; sifo of siwo, knuppelen; sosonotoko, uitsnijder, beitel; sonotoko, uitsnijden, beitelen; luluiti, strijkstok (viool), snijwerktuig; luiti, strijken, vioolstrijken, snijden;

babangini, onderstutter; pangini, onderstutten; bobángu, boete, betaalmiddel; fangu, betalen; gigirimanga, prop, kurk; kirimanga, van een prop, kurk voorzien, kurken; didini, naad; dini, naaien; wawáko, draaier (werktuig om touw te draaien); wako, draaien ; didibáko, dwarslegger; tibáko, dwarsleggen; dodotoko, leer, leering, onderwijs; dotoko, leeren; loleoto, ankerplaats, haven; leoto, in een haven voor anker gaan; 
guguiti, waterschepper, hoozer; uiti, uithoozen ;

didirine, beverigheid, gebeef ; tirine, beven;

lolómu, bijeenkomst; lomu, bijeenkomen, vergaderen;

loháhi, verzoek; lahi, verzoeken;

gagaatete, haak; kaatetc, aan elkaar blijven haken, van atctc,

blijven haken;

bebéno, wand, deur; beno, wand, afsluiting maken, ook: sluiten; ninizuiti, slijpsteen; izviti, slijpen, scherpen, aanzetten;

nanáo, onderlegger ; nao, onderleggen;

ngangawene, kleedingstuk; awene, aantrekken, kleeden;

ngangaeme, tong (wisselwoord voor asi-asiri) ; aeme, likken;

asi-asiri, tong ; asiri, slikken ;

dadanuru, beschermingsteeken bij boomen, planten, enz.; tanuru, zulk een teeken plaatsen;

gigisoko, dweil, natte lap; isoko, wasschen van vaatwerk, enz.; bobéro, groei ; fero, groeien;

dodádi, wording; dadi, worden;

momóku, draagstok, pikoelan; moku, op den schouder dragen;

babarasa, wig, pen; parasa, inslaan, inpennen, wiggen ;

babagara, bordenrek; pagara, op den buik liggen, vaatwerk enz. op den hollen kant leggen;

bobokusu, bezwering; wokusu, bezweren;

babatingi, voorbehoedmiddel; batingi, een grens, afscheiding maken;

o lari-lari, stelling voor het omkappen van boomen, waarvan men, zoodra de boom kraakt, afspringt; van Mal. lari, hardloopen ;

o tawi-tawi, bliksem; tawi, oogknippen.

\section{Adjectieven.}

Geven te kennen: a. een versterkte graad van de hoedanigheid; b. worden als attribuut gebezigd. Hoewel in vorm gelijk, zijn de beteekenissen verschillend:

ami ngowaka isiri-siri, haar kind is erg ziek;

ami ngowaka isiri-siri gećna, isongenokáu, haar kind, dat ziek

is (of : haar zieke kind) is gestorven;

awi saaka iamo-amoko, zijn passen, stappen zijn erg groot;

awi saaka iamo-amoko guúna kanginíka woboáno, hij, die met 
die groote passen (hij, die stap-allemachtig) is gisteren hier aangekomen ;

o kokonjówo ikukuarcne, een pak sago, dat zeer licht is;

o kokonjówo ikukuarcne geéna tongonáu, dat lichte pak sago is het jouwe;

o namoro ititingoono, een vogel, die zeer klein is;

o namoro ititingoono ge tatoimokáu, die heele kleine vogel heb ik gepijld; enz. enz.

\section{Bijwoorden:}

$o$ zuange-wange, overdag; (wange, dag, zon);

o obi-obiri, 's nachts; (obiri, nacht);

o wange ikokoróna, 's middags (precies);

o obiri igogoróna, 's middernachts (precies);

$o$ wange ilenge-lenge, 's namiddags (wanneer de zon scheef staat) ;

itotoíngo, zeer lang (van tijd) ; kangano-ngano, zoo pas geleden, zoo eventjes (kangano, zooeven); siika-ika, voortaan; siadoadonika, voor altijd.

Werkwoorden.

1. De eerste beteekenis is reeds behandeld bij de betrekk. vnw. en komt in beteekenis overeen met de deelwoorden.

2. Een duratief- en frequentatiefvorm:

ngaro wooa-oara ma wadaenúwa, ofschoon hij steeds hard liep, hij achterhaalde 't niet;

o ngowaka ni lukama kajodoa-doa, de kinderen beklimmen maar voortdurend je langsatboomen;

o kaso mahipo-hiporo, siadono masosongene, zij sloeg dien hond herhaaldelijk, totdat $\mathrm{zij}$ hem doodde;

o dadoko ihoa-hoa so o duriani kaitia'a-tizuáku, de wind is steeds aan 't blazen, zoodat de doerianvruchten maar herhaaldelijk naar beneden vallen.

3. In sterke mate:

ona joie-iete de ma dodogumúwa, zij lachen zóó, dat er geen eind aan komt; 
manga damunu jatako-takoro, ma ilingi isikctíka, zij slaan zoo geweldig op hun trommen, dat het geluid overal heen weerkaatst;

jooru-oru de o moku-moku iparcnúku, zij roeien zoo geweldig, dat de golven in (de prauw) slaan.

4. Een vierde beteekenis is: zich voordoen als; op z'n:

wokoa-koana, hij doet alsof hij vorst is, hij stelt zich als vorst aan, (van koana, vorst);

josae-sacke, zij stellen zich aan als hoofden, (van sacke, hoofd); jokoko-koko, zij gaan uit vampyren, zij doen zich als vampyi voor, (van koko, een nachtvogel, die als vampyr gedoodverfrl wordt);

wosusuúru (van Suúru $=$ Saoe), hij spreekt op z'n Saoesch.

hij spreekt de Saoesche taal;

wotatabáru (van Tabáru), hij spreekt Tabaroesch;

poibu-ibu (van $I b u)$, Iboesch spreken;

ona jototodóre $(\operatorname{van}$ Todóre $=$ Tidore $)$, zij spreken Tidoreesch.

B ijvoeglijke naamwoorden.

1. De bijv.nww. worden gevormd, evenals de werkwoorden bij de vervoeging, door voorvoeging van de pers. vnww. Hoewel zij niet als w.w. beschouwd worden, zijn zij in vorm daaraan gelijk:

guina wopululunu, die hij, hij is dik;

muna mopelelaka, zij, zij is mager;

o Suuróka o njawa jotingoono, de Saoeërs, (zijn) menschen, die klein zijn;

masira mijosolimóngo, neéna mijotjazuáro, vroeger waren wij dom, thans zijn we verstandig;

o woa itero, het huis is mooi;

o tapaki ipepéke, de weg is vuil;

o sarimi ge itipóko, die pagaai is kort.

2. a. In attributieve beteekenis; b. ter versterking van den graad van hoedanigheid worden zij geredupliceerd:

wokaku-kakuru guúna kawaadoniéw'a, die lange kan er zelfs niet bij (reiken);

ni kaso igoli-goli geéna ma ingiri itodo-todomo, die bijtende hond van je, z'n tanden zijn zeer scherp; 
ami biono ibango-bangoro, haar gelaat is zeer schoon.

3. Door de vorming met den genitiefaanduider ma (en de bezitt. vnww) worden ook adjectieven gevormd, die in vorm substantieven zijn, doch in beteekenis adjectieven:

o ngowaka itingoono, 'n kind is klein;

o ngoz'aka madingoono, de kleinheid van 'n kind = 'n klein kind;

o soana ipiakoro, 't dorp is uitelkaar gegaan;

o pipi mabiakoro, de verkleining van geld $=$ verkleind geld $=$ klein-geld;

o njawa joodumu, menschen alle;

awi roese mangodumu, de heelheid van z'n lichaam = een geheel lichaam (zonder lichaamsgebreken);

o pipi mangodumu, heel-, groot-geld;

o nauru jokudái, mannen, zij (zijn) veel;

o ngeweka manga gudái, vrouwen hun veelte $=$ veel vrouwen; enz.

4. De stoffelijke bijv.nww. worden gevormd door samenstelling met het substantief, waarbij het attribuut ook in substantiefvorm optreedt :

o ali-ali o saaka, 'n zilveren ring;

$o$ woa o teto, 'n steenen huis;

o dodóku o gota, 'n houten brug;

o bebéno o tonga, 'n bamboe-bewanding, wand van bamboe;

o saeke o gurátji, 'n gouden hoofd;

o kapali o besi, 'n ijzeren schip;

o njazia-njawa o sutaráa, 'n zijden pop.

5. Afgeleide adjectieven worden gevormd door voorvoeging van het geredupliceerde prefix $k a$ en hebben de beteekenis van onze met -ig gevormde adjectieven:

ikakatcto, steenachtig; ikakasurono, gaterig, met gaten; ikakatingásu, hellingachtig, met hellingen; ikakasisika, doornig, doornachtig; enz.

\section{Verge lijking.}

Ons ,even”, „,gelijk” wordt weergegeven met tero, gelijk; matero, zich gelijk; imatero, 't zich gelijk; versterkte vorm met ka: kaimatero, precies, juist zich gelijk. 
touna wi ilingi de o ngewéka mi ilingi imatero, zijn stem(geluid) en een vrouw haar stem zijn zich gelijk;

of : touna awi ilingi imatero o ngeweka mi ilingi, zijn stem is gelijk aan de stem van 'n vrouw;

onana Domáha ona manga biono kainatero, de gezichten van de Domaha's zijn precies aan elkaar gelijk.

„Evenals”, ,gelijk aan”, ,alsof”, ,zooals”, vormt men met het woordje iso of isoka: tjei, nomatotéru iso ngona o koana, foei, je stelt je aan alsof je een vorst waart;

isoka ni dea wonisidemo, kogećna namoteke, zooals je vader 't je aangezegd heeft, aldus volg het op;

ma beréki gumnina mi ilingi isoka o tokata, de stem van dat oudje is gelijk (evenals) aan de stem van een vampyr.

De zin: ,,jouw huis is grooter dan het mijne”, kan op verschillende wijzen weergegeven worden.

B.v. tongoi $i$ woa de tongona ma, tongona iamoko, mijn huis en 't jouwe, doch het jouwe is groot(er); of : tongoi $i$ woa ma, tongona ianoko, mijn huis, doch 't jouwe is groot(er).

Deze beide vormen doen dienst om den comparativus weer te geven. Zoo ook het woordje foloi, meer, doet als zoodanig dienst:

o Suuróka de o Tabaruóka, ifolói o Tabaruóka manga adati itcro. de Saoeërs en de Tabaroes, meer juist is de adat der Tabaroes;

o Bitie de ngo Buséngi, ifolói ngo Buséngi mi gumuru, Busengi is ouder (meer oud) dan Bitië.

Bij telwoorden gebruikt men ipaili, 't is er boven, 't is meer: o rupía monaoko de o liári monaoko, ipaili o liári; of : o rupía monaoko ma ipaili o liári monaoko, 20 realen zijn meer dan 20 gulden.

Bij den excessief en superlatief doen dienst het suffix oli, weer, nog weer; ikudái, veel; ikukudái, zeer veel; en de reduplicatie van het adjectief :

ni mongóo iamokóli, jouw vadem is te groot, veel te groot; tongom mia aha ma touna ikukudái, hij heeft de meeste sagotuinen van ons. 